\title{
Article
}

\section{The Bill of Rights and}

\section{the Fourteenth Amendment}

\author{
Akhil Reed Amar $\dagger$
}

\section{CONTENTS}

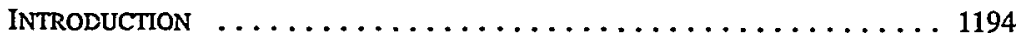

I. ANTEBellum IdeAs $\ldots \ldots \ldots \ldots \ldots \ldots \ldots \ldots \ldots \ldots \ldots \ldots \ldots$

A. Barron ............................... 1198

B. The Barron Contrarians .................. 1203

1. The General WordinglExpressio Unius Theory ....... 1204

2. The Declaratory Theory .................. 1205

C. The Contrarian Context .................. 1212

1. Technology, Geography, and Ideology . . . . . . . 1212

2. Slavery ........................ 1215

II. THE EASY CASE For INCORPORATION $\ldots \ldots \ldots \ldots \ldots \ldots \ldots \ldots \ldots$

A. The Text of the Fourteenth Amendment . . . . . . . . . . 1218

1. "No State shall ..." ........................ 1218

2. ". . make or enforce any law which shall abridge ..." . 1219

3. "... the privileges or immunities ..." . . ........ 1220

4. "... of citizens of the United States;" . . . . . . . . 1222

5. "... nor shall any State deprive any person of life, liberty, or property, without due process of law;" . . . . . . 1224

6. Beyond Mechanical Incorporation . . . . . . . . . 1227

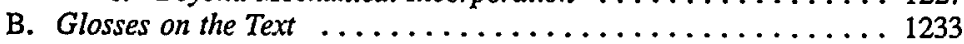

1. The Thirty-ninth Congress .................. 1233

a. The Easy Case Made Easier ............. 1233

† Professor, Yale Law School. This Article is a sequel to Akhil Reed Amar, The Bill of Rights as a Constitution, 100 YALE L.J. 1131 (1991). Both essays are part of a larger book-length treatment of the Bill of Rights to be published next year. 
b. Incorporating Anti-Incorporation Insights ... . . 1238

(i) Fairman .................... 1238

(ii) Berger . . . . . . . . . . . . . . . . . . . 1243

2. Ratification: The Sounds of Silence . . . . . . . . . . 1246

a. Ratification Silence and the Incorporation Debate ... 1246

b. Ratification Silence More Generally . . . . . . . . 1251

3. Early Interpretations: In Search of Reasons . . . . . . . . 1254

III. THE HARd PART OF INCORPoRATION $\ldots \ldots \ldots \ldots \ldots \ldots \ldots \ldots . . \ldots$

A. The Problem: Fitting the Constitution's Pegs into Reconstruc-

tion Holes . . . . . . . . . . . . . . . . . . . . . . 1260

B. The Solution: Refined Incorporation .............. 1262

1. Total and Selective Incorporation Revisited . . . . . . 1262

2. A New Synthesis ...................... 1264

3. A Founding Analogy ................. 1266

4. The Old Roots of the New Synthesis ............. 1268

C. "Refined Incorporation" Applied: The Rights of Expression . . . 1272

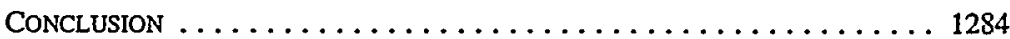

\section{INTRODUCTION}

What is the relationship between the Bill of Rights and the Fourteenth Amendment? Does the Amendment "incorporate" the Bill, making the Bill's restrictions on federal power applicable against states? If so, which words in the Fourteenth Amendment work this change? Are all, or only some, of the provisions of the first ten amendments "incorporated" or "absorbed" into the Fourteenth? If only some, which ones, and why? Once "incorporated" or "absorbed," does a right or freedom declared in the Bill necessarily constrain state and federal governments absolutely equally in every jot and tittle? Or, on the other hand, can a guarantee in the Bill ever lose something in the translation, so that only a part of the guarantee-perhaps only its "core"-applies against state governments by dint of the Fourteenth Amendment?

These questions have framed a debate that, in the words of Judge Henry Friendly, "go[es] to the very nature of our Constitution" with "profound effects for all of us." Professor Van Alstyne has written that "it is difficult to imagine a more consequential subject,"2 an assessment confirmed by the extraordinary number of twentieth-century legal giants who have locked horns in the debate-Hugo Black, Felix Frankfurter, William Brennan, Henry Friendly, William Crosskey, Louis Henkin, Erwin Griswold, and John Ely, to name only a few. Perhaps even more extraordinary has been the willingness of Supreme Court Justices to reinforce their judicial pronouncements on the issue with extra-judicial elaborations. For example, after his retirement from the bench and shortly before his death, Justice Frankfurter published as his parting words to (1965).

1. Henry J. Friendly, The Bill of Rights as a Code of Criminal Procedure, 53 CAL. L. REv. 929, 934

2. William W. Van Alstyne, Foreword to Michael Kent CuRTis, No State Shall ABridge: The FOURTEENTH AMENDMENT AND THE BILL OF RIGHTS, at ix (1986). 
the legal community an elaborate "memorandum" on "incorporation" in the Harvard Law Review, piling up case citations and other material to support his own preferred solution to the issue. ${ }^{3}$ Three years later, Frankfurter's great sparring partner, Justice Black, publicly responded in his Carpentier Lectures, breaking "a longstanding rule of not speaking out on constitutional issues." And in two James Madison Lectures delivered twenty-five years apart-each aptly titled "The Bill of Rights and the States"-Justice Brennan expanded upon his own proposed solution to the incorporation conundrum. ${ }^{5}$

When we shift our attention from lectures and law reviews to United States Reports, we see much more evidence of the centrality of the incorporation debate to twentieth-century constitutional law. Consider, for example, the lead paragraph of the most famous footnote in Supreme Court history: "There may be narrower scope for operation of the presumption of constitutionality when legislation appears on its face to be within a specific prohibition of the Constitution, such as those of the first ten amendments, which are deemed equally specific when held to be embraced within the Fourteenth." ${ }^{\prime \prime}$ In the half-century since Carolene Products, the Court has taken the hint of footnote four. A list of cases applying various parts of the Bill of Rights against states reads like the "greatest hits" of the modern era: New York Times v. Sullivan, ${ }^{8}$ Abington School District v. Schempp, ${ }^{9}$ Mapp v. Ohio, ${ }^{10}$ Miranda v. Arizona, ${ }^{11}$ Gideon v. Wainwright, ${ }^{12}$ Duncan v. Louisiana, ${ }^{13}$ and on and on. Some cases, like Sullivan, merely applied provisions of the Bill of Rights that had long before been deemed "embraced within" the Fourteenth Amendment; others, like Duncan, achieved notoriety precisely because they decided to "incorporate" previously "unabsorbed" clauses. Speaking only of the latter set, Justice Brennan ranked the incorporation opinions ahead of reapportionment and desegregation cases as "the most important [series of decisions] of the Warren era." 14 In remarks sharply critical of Brennan and his brethren, Solicitor Gen-

3. Felix Frankfurter, Memorandum on "Incorporation" of the Bill of Rights Into the Due Process Clause of the Fourteenth Amendment, 78 HARV. L. REV. 746 (1965). Judge Friendly notes that this memorandum was Frankfurter's "Iast published work." Friendly, supra note 1, at 934 n.27.

4. William C. Warren, Foreword to Hugo LAFAYETTE BLACK, A CONSTIUUTIONAL FAITH, at $x$-xi (1968); HUGO LAFAYETTE BLACK, A CONSTITUTIONAL FATTH, at xvi-vii, 34-42 (1968).

5. William J. Brennan, Jr., The Bill of Rights and the States, 36 N.Y.U. L. REV. 761 (1961) [hereinafter Brennan I]; William J. Brennan, Jr., The Bill of Rights and the States: The Revival of State Constitutions as Guardians of Individual Rights, 61 N.Y.U. L. REV. 535 (1986) [hereinafter Brennan II].

6. United States v. Carolene Products Co., 304 U.S. 144, 152 n.4 (1938).

7. This phrase is meant to suggest the importance of the cases and not necessarily their correctness.

8. 376 U.S. 254 (1964) (freedom of speech and press).

9. 374 U.S. 203 (1963) (nonestablishment of religion).

10. 367 U.S. 643 (1961) (exclusion of evidence obtained by unreasonable search and seizure); see also id. at 661-66 (Black, J., concurring) (relying in part on right against compelled self-incrimination).

11. 384 U.S. 436 (1966) (privilege against compelled self-incrimination and right to counsel).

12. 372 U.S. 335 (1963) (right to counsel).

13. 391 U.S. 145 (1968) (right to criminal jury).

14. Brennan II, supra note 5, at 535-36; see also William J. Brennan, Jr., State Constitutions and the Protection of Individual Rights, 90 HARv. L. REV. 489, 492-93 (1977). 
eral Erwin Griswold offered an even more sweeping assessment of the stakes involved: "I can think of nothing in the history of our constitutional law which has gone so far since John Marshall and the Supreme Court decided Marbury v. Madison in 1803."15

And yet, despite the importance of the topic and all the attention devoted to it, we still lack a fully satisfying account of the relationship between the first ten amendments and the Fourteenth. Minor variations aside, three main approaches have dominated the twentieth-century debate. The first, represented by Justice Frankfurter, insists that, strictly speaking, the Fourteenth Amendment never "incorporated" any of the provisions of the Bill of Rights. ${ }^{16}$ The Fourteenth requires only that states honor basic principles of fundamental fairness and ordered liberty - principles that might indeed happen to overlap wholly or in part with some of the rules of the Bill of Rights, but that bear no logical relationship to those rules. The second approach, championed by Justice Black, insists on "total incorporation" of the Bill of Rights. ${ }^{17}$ The Fourteenth Amendment, claimed Black, made applicable against the states each and every provision of the Bill, lock, stock, and barrel-at least if we define the Bill to include only the first eight amendments. Faced with these diametric views, Justice Brennan tried to steer a middle course of "selective incorporation."18 Under this third approach, the Court's analysis could proceed clause by clause, fully incorporating every provision of the Bill deemed "fundamental" without deciding in advance whether each and every clause would necessarily pass the test. Methodologically, Brennan's approach seemed to avoid a radical break with existing case law rejecting total incorporation, and even paid lip service to Frankfurter's insistence on fundamental fairness as the touchstone of the Fourteenth Amendment. In practice, however, Brennan's approach held out the possibility of total incorporation through the back door. For him, once a clause in the Bill was deemed "fundamental" it must be "incorporated" against the states in every aspect, just as Black insisted. And nothing in the logic of selective incorporation precluded the possibility that, when all was said and done, virtually every clause of the Bill would have been deemed fundamental.

As we shall see, there is something to be said for each of these positions, but each is also fatally flawed. An alloy of the three seemingly incompatible elements will prove far more attractive and durable than each unalloyed component. But before such an alloy can profitably be forged, we need to do a

15. Erwin N. Griswold, Due Process Problems Today in the United States, in THE FOURTEENTH AMENDMENT 161, 164 (Bernard Schwartz ed., 1970) (citation omitted).

16. See Adamson v. California, 332 U.S. 46, 59-68 (1947) (Frankfurter, J., concurring); Frankfurter, supra note 3.

17. See Betts v. Brady, 316 U.S. 455, 474-75 \& n.1 (1942) (Black, J., dissenting); Adamson, 332 U.S. at 68-123 (Black, J., dissenting); Duncan, 391 U.S. at 162-71 (Black, J., concurring); BLACK, supra note 4 , at $34-42$.

18. See Ohio ex rel. Eaton v. Price, 364 U.S. 263, 274-76 (1960) (separate opinion of Brennan, J.); Cohen v. Hurley, 366 U.S. 117, 154-60 (1961) (Brennan, J., dissenting); Malloy v. Hogan, 378 U.S. 1 (1964) (Brennan, J.); Brennan I, supra note 5; Brennan II, supra note 5. 
considerable amount of preparatory work. In Part I, we shall examine antebellum ideas about whether the original Bill of Rights applied against the states. In Part II, we shall study with care the text and context of the Fourteenth Amendment. Finally, in Part III, we shall return to the Black-Brennan-Frankfurter debate, which I shall attempt to synthesize with a new model of incorporation.

This synthesis, which I call "refined incorporation," begins with Black's insight that all of the privileges and immunities of citizens recognized in the Bill of Rights became applicable against states by dint of the Fourteenth Amendment. But not all of the provisions of the original Bill of Rights were indeed rights of citizens. Some instead were at least in part rights of states, and as such, awkward to incorporate fully against states. Most obvious, of course, is the Tenth Amendment, but other provisions of the first eight amendments resembled the Tenth much more than Justice Black admitted. Thus, there is deep wisdom in Justice Brennan's invitation to consider incorporation clause by clause rather than wholesale. But having identified the right unit of analysis, Brennan posed the wrong question: Is a given provision of the original Bill really a fundamental right? The right question is whether the provision really guarantees a privilege or immunity of individual citizens rather than a right of states or the public at large. And when we ask this question, clause by clause, we must be attentive to the possibility, flagged by Frankfurter, that a particular principle in the Bill of Rights may change its shape in the process of absorption into the Fourteenth Amendment. This change can occur for reasons rather different from those offered by Frankfurter, who diverted attention from the right question by his jaundiced view of much of the original Bill and by his utter disregard of the language and history of the privileges or immunities clause. Certain hybrid provisions of the original Bill—part citizen right, part state right-may need to shed their state-right husk before their citizen-right core can be absorbed by the Fourteenth Amendment. Other provisions may become less majoritarian and populist, and more libertarian, as they are repackaged in the Fourteenth Amendment as liberal civil rights-" "privileges or immunities" of individuals - rather than republican political "right[s] of the people," as in the original Bill.

Before we can properly elaborate and evaluate this synthesis, we must cover a considerable amount of ground. The best place to begin our journey is Barron v. Baltimore. ${ }^{19}$

19. 32 U.S. (7 Pet.) 243 (1833). 


\section{ANTEBELluM IDEAS}

\section{A. Barron}

In 1833, the Supreme Court confronted for the first time the argument that a state government had violated one of the provisions of the Bill of Rights. Narrowly framed, the issue raised by Barron was whether the Fifth Amendment's takings clause limited not just the federal government, but states and municipalities as well. The Court, however, saw that the reasoning behind John Barron's contention radiated much further. Perhaps the Court could have ruled for Barron without necessarily implying that each and every prohibition of the Bill of Rights would thenceforth bind states. For example, unlike the takings clause, the words of the First Amendment explicitly spoke of "Congress" as the target of limitation; and the logic underlying other particular provisions may also have made it peculiarly awkward to apply them against states. But the reasoning behind Barron's contention clearly would have required state compliance with a vast number of Bill of Rights prohibitions whose general language and logic made them indistinguishable from the takings clause. If the Fifth Amendment phrase, "nor shall private property be taken for public use without just compensation" limited states, so too, it would seem, did the Fourth Amendment phrase "no warrants shall issue, but upon probable cause," the Eighth Amendment phrase "excessive bail shall not be required," and so on. Barron thus presented a question "of great importance," as Chief Justice Marshall acknowledged at the outset of his opinion for the Court. ${ }^{20}$ But Marshall immediately added that the question was "not of much difficulty," and went on to dismiss Barron's argument in less than five pages.

One can quibble around the edges, ${ }^{21}$ but the core of Marshall's argument is compelling. To be sure, the takings clause nowhere explicitly says that it ties the hands of the federal government only and not the states. But as Marshall explained, because state governments were already in place in the 1780's, the dominant purpose of the Constitution was to create, yet limit, a new central government. "[L]imitations on power, if expressed in general terms, are naturally, and, we think, necessarily applicable to the government created by the instrument"- that is, the federal government. ${ }^{22}$ Though he did not cite it by name, Marshall seems to have had in mind here the sweeping dictum of

20. Id. at 247.

21. For example, the Court suggested that the limits imposed on states by Article I, Section 10 were "generally" to protect citizens of other states, 32 U.S. (7 Pet) at 249. This characterization obscures the Federalist framers' view of the centrality of the attainder, ex post facto, and contracts clauses as protections against one's own state. See, e.g., Akhil Reed Amar, Of Sovereignty and Federalism, 96 YALE L.J. 1425, 1440-41 (1987), and sources cited therein. Marshall, of course, knew better. See Fletcher v. Peck, 10 U.S. (6 Cranch) 87, 138-39 (1810) (Marshall, C.J.) (Article I, Section 10 "may be deemed a bill of rights for the people of each state"). Marshall's Fletcher opinion went unmentioned in his Barron opinion.

22. 32 U.S. (7 Pet) at 247. 
Hamilton's Federalist No. 83: "The United States, in their united or collective capacity, are the OBJECT to which all general provisions in the Constitution must necessarily be construed to refer."23

Close inspection of the original Constitution confirms the soundness of the Hamilton-Marshall rule of construction. In Article I, Section 9, for example, we find a purely general prohibition akin to the takings clause in its language and logic: "No Bill of Attainder or ex post facto Law shall be passed." Yet as Marshall forcefully noted, ${ }^{24}$ this general prohibition limits only the federal government; hence the framers' inclusion of a separate clause explicitly limiting states, in Article I, Section 10: "No State shall . . . pass any Bill of Attainder [or] ex post facto Law." The absence of any similarly explicit language limiting states in the takings clause cut strongly against Barron's claim. Had the framers of the clause meant to limit states, wrote Marshall, "they would have declared this purpose in plain and intelligible language,"25 like the "No State shall" phrasing of Article I, Section 10.

But does not the language of the First Amendment cut exactly the other way, suggesting that where the Bill of Rights aimed at limiting only the federal government, it used an explicit word like "Congress" to signal that intent? Once again, Marshall offered a careful parsing of Article I, Section 9 to drive home his point: "Some of [the clauses in this section] use language applicable only to congress: others are expressed in general terms."26 If the word "Congress" in the First Amendment could justify applying the takings clause and other general wording in the Bill of Rights to the states, then the same should hold true for Article I, Section 9: the words "the United States" in the Section 9 clause-"No Title of Nobility shall be granted by the United States"- should logically imply that the general wording of the attainder and ex post facto clause of Section 9 applied against the states. Yet as we have seen, the Constitution plainly suggests otherwise. Marshall saw the language of Section 9 as especially relevant because it was "in the nature of a bill of rights,"27 as various Federalists had pointed out during the ratification period to counter Anti-Federalist concerns about the apparent absence of such a bill in the original Constitution. ${ }^{28}$

Purely as a matter of textual exegesis and application of lawyerly rules of construction, Marshall's argument is hard to beat. Why weren't the framers and ratifiers of the Bill of Rights entitled to rely on a natural and sensible rule of

23. The Federalist No. 83, at 503 (Alexander Hamilton) (Clinton Rossiter ed., 1961) thereinafter all citations to THE FEDERALIST are to this edition].

24. 32 U.S. (7 Pet.) at 248.

25. Id. at 250 .

26. Id. at 248 .

27. Id.

28. See, e.g., THE FEDERALIST No. 84, at 510-12 (Alexander Hamilton). 
construction implicit in the Constitution itself and made explicit by Publius in his influential defense of the document? $?^{29}$

The legislative history of the Bill of Rights confirms that its framers and ratifiers did so rely. Various state conventions endorsed amendments limiting the new central government, some phrased in general language, others using words explicitly targeted at the central government-“"Congress," the "United States," and so on..$^{30}$ Yet no one ever suggested that the general language, simply because of its juxtaposition with other clauses worded differently, would limit state governments as well. When Madison distilled these endorsements into his own list of proposed limitations, he suggested that most of these limitations be inserted in Article I, Section 9. Following the rule of construction implicit in that Article, he used general language and explicit references to Congress indiscriminately. ${ }^{31}$ The proposed location of these clauses made it clear that, however worded, they applied only against the federal government. But the first Congress eventually decided to put these amendments at the end of the original Constitution. There is no evidence that this change was anything but aesthetic. Nevertheless, the change had the unhappy effect of blurring the implicit rule of construction at work, creating an interpretive trap for the unwary, which Marshall gracefully avoided by keeping his eyes on Section 9 .

Unlike state ratifying conventions, Madison believed that additional restrictions in favor of liberty should also be placed on state governments and said

29. Professor Crosskey flails mightily against this rule of construction, but without much success. 2 WILLIAM WINSLOW CROSSKEY, POLITICS AND THE CONSTTTUTION IN THE HISTORY OF THE UNTTED STATES 1049-82 (1953). Crosskey offers two constitutional counterexamples that, he claims, disprove the rule that generally worded constitutional limitations never apply against states. Id. at 1079-80. The first claimed counterexample, the full faith and credit clause of Article IV, explicitly uses the word "State" twice. U.S. CoNsr. art. IV, § 1. Crosskey's attempt to argue that the phrase "in each State" does not include action by states makes a hash of the obvious interstate comity logic of the clause, confirmed by its placement in Article IV immediately preceding other obvious comity clauses-clauses that clearly use the phrases "in the several States," "in any State," and "in another State" to encompass action by states. U.S. CoNST. art. IV, $\$ 2$, cls. 1-2; see also id. art. VI (judges "in every State" in context clearly encompass judges of states).

Crosskey's only other example-the appellate jurisdiction of the Supreme Court-rests on a highly strained textual analogy to a set of words that looks very different from those of the takings clause. Unilike the takings clause, the appellate jurisdiction clause is not a limitation on, but an empowerment of, federal authority. Id. art. III, $\S 2$. To the extent the clause does implicitly limit federal authority-for example, by denying federal courts jurisdiction over nondiverse cases arising wholly under state law-these limitations apply only against federal courts and not state courts, in perfect keeping with Barron. What's more, the appellate jurisdiction clause must be read in the context of the language of Article III as a whole, which does make plain that state courts are to be reviewed by federal tribunals. See Akhil Reed Amar, A NeoFederalist View of Article III: Separating the Two Tiers of Federal Jurisdiction, 65 B.U. L. REV. 205 (1985). In the words of Publius, "The objects of appeal, not the tribunals from which it is to be made, are alone contemplated." THE FEDERALIST NO. 82, at 494 (Alexander Hamilton). Such was the near universal understanding in 1787-89. Crosskey, by contrast, fails to identify even a single 18th-century figure who thought that the Bill of Rights applied directly against states.

30. See, e.g., 1 DEBATES ON THE ADOPTION OF THE FEDERAL CONSTITUTION 322-23, 326-27 (Jonathan Elliot ed., AYER Co. reprint ed. 1987) (1836) [hereinafter ELLIOT's DEBATES] (ratifying conventions of Massachusetts and New Hampshire); 3 id. at 659-61 (Virginia ratifying convention).

31. 1 ANNALS OF CONG. 451-52 (Joseph Gales ed., 1791) (1st ed. pagination) (June 8, 1789) (speaking of "national" government and "the Legislature" in some provisions, yet using global language elsewhere (emphasis added)). 
so on the floor of the House; $; 2$ but even more important for our purposes, he proposed a constitutional amendment that used explicit language to communicate this idea - the very same explicit language that John Marshall seemed to be asking for in Barron: "No State shall violate the equal rights of conscience, or the freedom of the press, or the trial by jury in criminal cases. ${ }^{, 33}$ Moments earlier, Madison had proposed that the following general language be inserted into Section 9: "[N]or shall the full and equal rights of conscience be in any manner, or on any pretext, infringed ... and the freedom of the press . . . shall be inviolable. ${ }^{, 34} \mathrm{Had}$ this general wording, taken alone or in juxtaposition with references to Congress in nearby clauses, been understood to apply to states, Madison's "No state shall" proposal would have been horribly repetitive, eligible for inclusion in the department of redundancy department. ${ }^{35}$ What's more, in limiting its list of rights that "No State shall" abridge to press, conscience, and juries, Madison's wording clearly suggested under the principle of expressio unius that states could do other things prohibited by the general language of his proposed Section 9 insert. That general language, for example, prohibited both establishment of religion and infringement of conscience. Madison's "No State shall" list included the latter but pointedly omitted the former, thus implying that states would continue to be free to establish churches. But if so, we are again driven to the obvious rule of construction that the general language about establishment-like all general language-applied only to the federal government.

Still further corroboration comes from Madison's speeches on the House floor. Whereas he candidly admitted that his proto-Tenth Amendment "may be considered as superfluous" and "unnecessary," he described his "No State shall" proposal, in very different language: "[T] his [is] the most valuable amendment in the whole list" ${ }^{36}$ - valuable because it added something obviously not implicit elsewhere in general language. Yet he also noted that even this most valuable amendment would bind states only to "those particular rights"s7 listed in the "No State shall" clause, once again making clear that merely general language would not limit states. ${ }^{38}$

32. Id. at 454-55 (June 8, 1789); id. at 784 (Aug. 17, 1789).

33. Id. at 452 (June 8,1789 ) (emphasis added).

34. Id. at 451.

35. The redundancy here is of a different order than that embodied in Madison's proposed prototype of the Tenth Amendment, which used words very different from anything in the original Constitution to make textually explicit a structural idea only implicit earlier-the idea of limited federal power. And Madison was at pains to point out that whereas his proto-Tenth Amendment added nothing new, his protoFourteenth did. See infra text accompanying notes 36-38.

36. 1 ANNALS OF CONG., supra note 31, at $458-59$ (June 8, 1789); id. at 784 (Aug. 17, 1789).

37. Id. at 458 (June 8,1789 ).

38. Even the most vociferous 20th-century critic of the Barron rule, William Winslow Crosskey, concedes that the language of Madison's "No State shall" proposal makes it tough to argue that the other generally worded amendments limited states. But, he argues, when the Senate voted down Madison's pet proposal, the general amendments were automatically transformed into limitations on states. 2 CROSSKEY, supra note 29 , at $1066-76$. It's a clever argument, but there's no evidence to support it. Crosskey fails to 
So far, so good for Marshall's opinion. But what makes Barron's holding compelling is neither its technical parsing of Article I, nor its use of lawyerly rules of construction, nor even the narrow legislative history of the Bill of Rights in Congress. Rather, it is what Marshall near the end of his opinion called the "universally understood" historical background of the Bill of Rights. ${ }^{39}$ In state convention after state convention in 1787-88, Anti-Federalists voiced loud concerns about a new, distant, aristocratic, central government that was being called into existence. ${ }^{40}$ Many ultimately voted for the Constitution only because Federalists like Madison promised to consider a Bill of Rights soon after ratification. Madison of course kept his word, and knew that if he had not, states' rightists might have called a second constitutional convention to repudiate the basic structure of the Constitution he had labored so hard to build ${ }^{41}$ In short, without the good will of many moderate Anti-Federalists, prospects for the new Constitution looked bleak in 1787-88; and a Bill of Rights was the explicit price of that good will. But the Bill of Rights that AntiFederalists sought was a Bill to limit the federal government-not just for the sake of individual liberty, but also to serve the cause of states' rights. ${ }^{42}$ Madison and his fellow Federalists could hardly have placated their critics, or won over their skeptics, by sneaking massive new restrictions on states into apparently innocuous general language. Nor would Anti-Federalists in Congress or in states have knowingly allowed such a trojan horse through the gates. Madison did openly advocate a small number of additional restrictions on states-clearly labeled as such in a package wrapped in the words "No State shall"- but even that modest proposal was too much for a Senate jealously guarding states' rights.

Barron's holding thus kept faith with both the letter and the spirit of the original Bill of Rights. We should not be surprised, then, that the decision in Barron was unanimous, or that the Court repeatedly and unanimously reaf-

identify a single person-in the Senate, in the House, in the states, or in the newspapers--who claimed that the general words would bind states. Nor is it plausible prima facie to presume that the Senate-the federal branch specially structured to safeguard state governments from federal encroachment-actually sought to increase the number of "particular rights" binding states by rejecting Madison's pet proposal. Yet this is exactly what Crosskey claims the Senate must have intended. Crosskey does point to other actions simultaneously taken by the Senate behind closed doors, but these actually appear to cut just the other way, suggesting a states' rights explanation for the difference in wording between the First Amendment and the next seven.

As I explain in more detail in my forthcoming book, the action of the Senate and the precise language of the First Amendment's unique reference to "Congress" reflect a surprisingly widely held view that-unlike the domains addressed in Amendments II-VIII-the areas covered by the First Amendment simply lay beyond Congress' enumerated Article I, Section 8 powers.

39. 32 U.S. (7 Pet) 243, 250 (1833).

40. See generally Amar, supra note $t$.

41. See Paul Finkelman, James Madison and the Bill of Rights: A Reluctant Paternity, 1990 SUP. CT. REV. 301, 335.

42. See generally Amar, supra note $\dagger$. 
firmed Barron's rule over the next thirty-three years in cases involving the First, Fourth, Fifth, Seventh, and Eighth Amendments. ${ }^{43}$

\section{B. The Barron Contrarians}

Having worked hard to understand Barron, we now must work equally hard to understand the contrary view, especially if we are to make full sense of the language and logic of the Fourteenth Amendment. In the fifteen years before Barron, a considerable number of weighty lawyers implied in passing or stated explicitly that various provisions in the Bill did limit states. Writing for the Court in 1819, Justice William Johnson obliquely suggested that the Seventh Amendment's guarantee of civil juries applied to states; ${ }^{44}$ and the following year he stated even more explicitly in a separate concurrence that the double jeopardy clause "operates equally upon both [state and federal] governments, ${ }^{, 45}$ although even here, his statement was not free from ambiguity. $\mathrm{He}$ may simply have meant that the clause applied whenever either of two prosecutions for the same underlying conduct was federal, even if the other was by state officials in state court for a state law crime. That same year, however, the New York Supreme Court stated in dictum that the double jeopardy clause "operates upon state courts" even where both prosecutions were for state law crimes. ${ }^{46}$ In 1824, this view of the double jeopardy clause was pressed in the Massachusetts Supreme Court, yet neither the government's attorney nor the judges appeared to challenge it-perhaps because even without the clause, the Commonwealth recognized a common law double jeopardy right at least as broad. ${ }^{47}$ The following year, William Rawle published a widely read treatise on the Constitution in which he argued at length that virtually all the general

43. See Livingston v. Moore, 32 U.S. (7 Pet) 469, 482, 539, $551-52$ (1833) (Fourth and Seventh Amendments); Holmes v. Jennison, 39 U.S. (14 Pet) 540, 555, 582, 587 (1840) (opinions of Thompson \& Barbour, JJ.) (Fifth Amendment due process); Permoli v. New Orleans, 44 U.S. (3 How.) 589, 609 (1845) (First Amendment free exercise); Fox v. Ohio, 46 U.S. (5 How.) 410, 434-35 (1847) (Fifth Amendment double jeopardy); Town of East Hartford v. Hartford Bridge Co., 51 U.S. (10 How.) 511, 539 (1850) (Fifth Amendment just compensation); Smith v. Maryland, 59 U.S. (18 How.) 71, 72, 76 (1855) (Fourth Amendment); Withers v. Buckley, 61 U.S. (20 How.) 84, $89-91$ (1857) (Fifth Amendment just compensation); Pervear v. Massachusetts, 72 U.S. (5 Wall.) 475, 476, 479-80 (1866) (Eighth Amendment).

The only troubled note in this unanimous chorus was sounded by Justice McLean in a pair of double jeopardy dissents. See Fox, 46 U.S. (5 How.) at 438-40 (McLean, J., dissenting); Moore v. Illinois, 55 U.S. (14 How.) 13, 21-22 (1852) (McLean, J., dissenting). McLean never claimed that the Fifth Amendment barred a state from punishing the same person twice for the same offense; but he did think that the Amendment, in tandem with its counterpart double jeopardy clauses in the state constitutions, prevented the federal and state governments from each punishing the same person once for the same conduct. See infra text accompanying notes 45,55 .

44. Bank of Columbia v. Okely, 17 U.S. (4 Wheat.) $235,240-42$ (1819). For a parsing of Johnson's language as inconsistent with the later Barron opinion, see William Winslow Crosskey, Charles Fairman, "Legislative History," and the Constitutional Limitations on State Authority, 22 U. CHI. L. REV. 1, 127-29 (1954).

45. Houston v. Moore, 18 U.S. (5 Wheat.) 1, 33-34 (1820) (separate opinion of Johnson, J.).

46. People v. Goodwin, 18 Johns. 187, 200-01 (N.Y. Sup. Ct. 1820).

47. Commonwealth v. Purchase, 19 Mass. (2 Pick.) 521, 522 (1824). 
provisions of the Bill of Rights bound states. ${ }^{48}$ And as late as 1833 , the year Barron came down, we find Justice Baldwin on circuit implying that the Second and Fourth Amendments applied against states, ${ }^{49}$ and Justice Story in his own treatise on the Constitution taking an uncharacteristically agnostic, even nonchalant, position on the whole matter:

It has been held in the state courts, (and the point does not seem ever to have arisen in the courts of the United States,) that [the Eighth Amendment] does not apply to punishments inflicted in a state court for a crime against such state; but that the prohibition is addressed solely to the national government, and operates, as a restriction upon its powers. ${ }^{50}$

\section{The General Wording/Expressio Unius Theory}

What were these lawyers and judges thinking? Some may simply have not given much thought to the Barron issue, especially where the case at hand was disposed of on other grounds. And a merely casual look at, say, the double jeopardy clause might lead a judge to assume it applied to states as well; for as New York Chief Justice Ambrose Spencer noted, the language of the clause was "general in its nature, and unrestricted in its terms." attention to the matter and added an expressio unius argument that the contrast between the First Amendment's specific reference to Congress and the general language of various later amendments confirmed that they, unlike the First, applied to states. ${ }^{52}$ As we have seen, Marshall refuted both of these arguments by his careful attention to Article I, Section 9. (What's more, the framers' reference to "Congress" in the First Amendment had nothing to do with the Barron issue; rather, it was probably an expression of the strong states' rights view that, unlike the areas addressed by later amendments, the First encompassed domains where Congress lacked enumerated power under Article I, Section 8. $)^{53}$ When forced to focus on this issue and only this issue in Barron, and when confronted by Marshall's textual analysis and historical narrative, Johnson and Baldwin reversed course, and Story fell into line.

Barron, however, was hardly the last word, and the contrary view continued to find expression over the next thirty-three years. At times it appears that lawyers, having simply never heard of Barron and its progeny, casually as-

48. William RaWle, a View of the CONSTitution of the UNTted STates of AMERICA 120-30 (Philadelphia, H.C. Carey \& I. Lea 1825).

49. Johnson v. Tompkins, 13 F. Cas. 840, 849-52 (C.C.E.D. Pa. 1833) (No. 7416).

50. 3 JOSEPH STORY, COMMENTARIES ON THE CONSTITUTION OF THE UNTTED STATES § 1897 (Boston, Hilliard, Gray \& Co. 1833). This language-the sum total of the Commentaries' analysis of the Barron issue-appears to have been written before Barron, though Story did manage to include in the published edition a footnote citation to Barron. See Crosskey, supra note 44, at 138-39.

51. People v. Goodwin, 18 Johns. 187,200 (N.Y. Sup. Ct. 1820).

52. RAWLE, supra note 48 , at 120 .

53. I elaborate this theme in more detail in my forthcoming book. 
sumed, along with Spencer or Rawle, that the general language of various provisions made application to states obvious. Thus in 1845, the Illinois Supreme Court noted in passing that the Fifth Amendment's due process clause limited state action, ${ }^{54}$ and two years later Ohio Attorney General Stanberry glibly conceded in oral argument before the U.S. Supreme Court that double jeopardy was "forbidden, as well to the States as to the general government, by the fifth ... amendment ${ }^{\text {." }}{ }^{55}$ Like Justice Johnson thirty years earlier, however, Stanberry may have meant to limit his concession to situations where one of the two prosecutions was federal, and the other state. Most important for our purposes, we must note that several capable lawyers in the Thirty-ninth Congress, the Congress that drafted the Fourteenth Amendment, seemed unaware of Barron until the case was brought to their attention by name by John Bingham, the principal draftsman of Section One of the Amendment. ${ }^{56}$

\section{The Declaratory Theory}

It is tempting to dismiss all these folks as dolts, but we must resist. Modern academic law schools did not exist. Supreme Court reports were not as widely available as nowadays. And constitutional law took a back seat to common law in its importance to everyday legal practice. (Thus, one of the biggest constitutional issues of the antebellum era was whether the vast domain of common law was state law or federal law.) Would-be lawyers began their training with Blackstone's Commentaries, not United States Reports.

But once we remember the centrality of Blackstone and the common law, we can see the Barron issue in a new light. For the common law method involved careful examination of codes, charters, statutes, and the like in an effort to distill their animating principles-the spirit of the common law. Judges did not simply "make up" common law; they "found" it in authoritative legal sources, such as Magna Charta, the Petition of Right, the Habeas Corpus Act, and so on. Thus, even if the Bill of Rights did not, strictly speaking, bind the states of its own legislative force, was it not at least declaratory of certain fundamental common law rights? And should not these declarations by We the People inform a state judge's analysis?

Thus we find Rawle in 1825 going beyond his narrow expressio unius argument by claiming that certain amendments "form parts of the declared rights of the people."57 Tellingly, he stressed the preamble of the Second Amendment as "a declaration that a well regulated militia is necessary to the security of a free state." 58 Only after discussing the preamble alone did he

\footnotetext{
54. Rhinehart v. Schuyler, 7 Ill. (2 Gilm.) 473, 522 (1845).

55. Fox v. Ohio, 46 U.S. (5 How.) 410, 420 (1847).

56. See infra text accompanying notes 189-195.

57. RAWLE, supra note 48 , at 120 (emphasis added).

58. Id. at 121 (emphasis added).
} 
quote its "corollary" that "the right of the people to keep and bear arms shall not be infringed," whose language, Rawle noted, was perfectly general..$^{59}$ Rawle then immediately invoked the English Bill of Rights of 1689 and Blackstone's analysis of the English common law right to bear arms. ${ }^{60}$ For Rawle, all this suggested that the Second Amendment bound states. Nor did the Tenth Amendment stand in the way, for Rawle read its final clauses as acknowledging that "the people" had certain reserved rights in contradistinction to-and against-" the states." 61

Rawle's analysis and language here were perhaps no more than suggestive, but they sketched out lines of argument that later Barron contrarians would develop more fully. Narrowly understood, the "declaratory" view of the Bill of Rights could provide even state courts with principled rules of decision, both procedural and substantive, when no state statute spoke directly to a given issue. Such, for example, was the situation in the New York and Massachusetts double jeopardy cases in the 1820's. More broadly, the Bill could serve as a source of maxims, both political and judicial. Politically, a maxim like the preamble to the Second Amendment could warn the people of any state to be wary of any legislature, even a state legislature, that sought to disarm them. ${ }^{62}$ Judicially, maxims drawn from the Bill of Rights could generate a set of rules of construction-what we would call today "clear statement rules"-obliging a state legislature to speak with unmistakable clarity before trenching on a right "declared" in the U.S. Constitution. And in the hands of a strong believer in fundamental or natural rights, the "declaratory" view of the Bill could have even more far-reaching consequences.

As modern day legal positivists, we tend to view the Bill as creating or conferring legal rights. But the congressional resolution accompanying the Bill explicitly described some of its provisions as "declaratory." ${ }^{33}$ To a nineteenthcentury believer in natural rights, the Bill was not simply an enactment of We the People as the Sovereign Legislature bringing new legal rights into existence, but a declaratory judgment by We the People as the Sovereign High Court that certain natural or fundamental rights already existed. ${ }^{64}$ Under this view, the

59. Id. at 122 .

60. Id. at 122-23.

61. Id. at $120-21$.

62. On the general role of maxims in Bill of Rights, see Amar, supra note $\bar{\dagger}$, at 1208-09.

63. 2 DOCUMENTARY HISTORY OF THE CONSTTTUTION OF THE UNITED STATES OF AMERICA 321 (Washington, Dep't of State 1894).

64. For a nice elaboration of this concept, see Jeff Rosen, Note, Was the Flag Burning Amendment Unconstitutional?, 100 YALE L.J. 1073, 1081-82 (1991). See also JACOBUS TENBROEK, EQUAL UNDER LAW 90-91, 128 (Collier Books 1965) (1951) (early amendments seen by contrarians as "declaratory constitutional safeguards of natural rights" and "a meeting ground of constitutional and natural rights"); Howard Jay Graham, Our "Declaratory" Fourteenth Amendment, 7 STAN. L. REV. 3, 3-4 (1954) (noting centrality of 18th- and 19th-century conception of various constitutional provisions as "declaratory"); cf. 2 ELLIOT's DEBATES, supra note 30, at 433 (remarks of James Wilson at Pennsylvania ratifying convention) (describing People as the Ultimate Supreme Court: "from their power, ... there is no appeal"); WILLIAM E. NELSON, THE FOURTEENTH AMENDMENT 59 (1988) (quoting 1867 Pennsylvania legislator describing constitutional 
First Amendment was not merely an interpretation of the positive law code of the original Constitution, declaring that Congress lacked Article I, Section 8 enumerated power to regulate religion or suppress speech; the Amendment was also a declaration that certain fundamental "rights" and "freedoms"- of assembly, petition, speech, press, and religious exercise-preexisted the Constitution. Why else, it might be asked, did the Amendment speak of "the" freedom of speech, implying a preexisting entitlement? ${ }^{65}$ The Ninth and Tenth Amendments did more than make explicit rules of construction for interpreting the Constitution as a positive law code; they also declared that certain "rights" and "powers" were retained by "the people" and "reserved" to them in contradistinction to "states."

Technically speaking, perhaps the Bill did not bind state governments of its own legislative force. But under the strong declaratory view, the result was virtually the same. An honest state court would be bound-though the precise nature of the obligation, legal or moral, was somewhat fuzzy-to respect "declarations" of the High Court of We the People that certain "rights" and "freedoms" existed. ${ }^{66}$ Unlike Rawle's expressio unius argument, demolished by Barron, this was an argument that states might be constrained even by the First Amendment-at least, by those clauses of the First Amendment that spoke of "rights" or "freedoms." (The establishment clause most distinctly did not.)

The obligation here would seem at least as strong as the duty of the honest common law judge to consider well reasoned precedents from well respected sister courts in other jurisdictions. Or to take an example from modern day Supreme Court case law, the obligation roughly mirrored the later rule that federal judges should consult state constitutions and state statutes to determine what punitive practices are violations of contemporary morality and thus "cruel

amendments as submitted to the people "sitting as a jury"-that is, a judicial body). J.).

65. See United States v. Given, 25 F. Cas. 1324, 1325 (C.C.D. Del. 1873) (No. 15,210) (Strong, Circuit

66. Consider, for example, Massachusetts Chief Justice Lemuel Shaw's remarks in a prominent mid19th-century case involving a claim of right against the state: "[T]he amendments of the Constitution of the United States, in the nature of a bill of rights, [should be regarded] as the annunciation of great and fundamental principles, to be always held in regard, both morally and legally, by those who make and those who administer the law [rather than as mere] precise and positive directions and rules of action . . . ." Jones v. Robbins, 74 Mass. (8 Gray) 329, 340 (1857); see also Bradshaw v. Rogers, 20 Johns. 103, 106 (N.Y. Sup. Ct. 1822). In Bradshaw, Chief Justice Spencer invoked the Fifth Amendment just compensation clause-the same clause later at issue in Barron-against a state law. Though conceding that the clause might lack "binding constitutional force upon the act under consideration" since the clause "related to the powers of the national government, and was intended as a restriction on that government," Spencer went on to argue that the clause was "declaratory of a great and fundamental principle of government; and any low violating that principle must be a nullity." (emphasis added). For similar views, see Bonaparte v. Camden \& A.R. Co., 3 F. Cas. 821,828 (C.C.D.N.J. 1830) (No. 1617) (Baldwin, Circuit J.) ("Though it may well be doubted whether as a constitutional provision, [the Fifth Amendment takings clause] applies to the state governments, yet it is the declaration of what in its nature is in the power of all governments, and the rights of its citizens ....") (emphasis added); Sinnickson v. Johnsons, 17 N.J.L. 129, 145-46 (1839) (dictum) (citing Barron yet embracing declaratory theory of just compensation clause). 
and unusual" within the meaning of the Eighth Amendment. ${ }^{67}$ More expansively, it could be argued that the ratification of the Bill by the collective state legislatures estopped these bodies from denying that certain rights and freedoms existed. How, for example, could a state legislature disarm its people after it had ratified a document declaring that "A well regulated Militia [is] necessary to the security of a free State?"

But how does all this fancy theorizing deal with the obvious objection that even if the Bill "declared" "rights" and "freedoms," it declared them only against the federal government? How could these declarations become transmogrified into limitations on states? There are really two objections here-one jurisprudential, and one constitutional. The jurisprudential objection is best framed by the work of the early twentieth-century legal analyst, Wesley Hohfeld, who insisted that "rights" logically implied correlative "duties" imposed on discrete persons or entities. ${ }^{68}$ The nature of a right is thus defined every bit as much by the party against whom the right runs as by its substantive sweep. The analytic truth of Hohfeld's insight is hard to quarrel with, but it would be anachronistic to read this insight back into all rights rhetoric, especially natural rights rhetoric, in mid- to late-nineteenth-century America. Hohfeld, after all, was responding to nineteenth-century judges and lawyers who were using the word "right" more loosely-sloppily, Hohfeld argued.

This emphasis on the word "right" also helps answer the constitutional objection rooted in Barron. Marshall insisted on reading the Bill of Rights with the same rules of construction implicit in the original Constitution, especially Article I, Section 9. This is a view deeply supportive of the vision of the Bill that I have elsewhere elaborated-a view of the Bill as fundamentally analogous to the original Constitution, intertwining structure (especially federalism) and rights. ${ }^{69}$ But the declaratory view insisted that rights were different from structure. Here was a powerful wedge to break the linkage Marshall sought to forge between Article I, Section 9 and the Bill of Rights. For Section 9 never invoked the word "rights" in either its general or specific language. (Indeed, the only place where the word "right" appeared in the original Constitution was-of all places!- - the Article I, Section 8 copyright clause. ${ }^{70}$ ) The closest thing Section 9 offered to a declaration of right was its affirmation of "the

67. See, e.g., Stanford v. Kentucky, 492 U.S. 361, 369-72 (1989). Compare, for example, Chancellor James Kent's opinion in Gardner v. Trustees of Newburgh, 2 Johns. Ch. 162, 165-68 (N.Y. Ch. 1816), where the great jurist applied the just compensation requirement to a state statute despite the absence of any express language in the state constitution. After canvassing the "soundest authorities" of Grotius, Puffendorf, and Blackstone, and the express language of the Pennsylvania, Delaware, and Ohio state constitutions, Kent proclaimed: "But what is of higher authority, and is absolutely decisive of the sense of the people of this country, [the principle] is made a part of the Constitution of the United States, 'that private property shall not be taken for public use without just compensation' ...."

68. Wesley N. Hohfeld, Some Fundamental Legal Conceptions as Applied in Judicial Reasoning, 23 YALE L.J. 16 (1913).

69. See Amar, supra note $t$.

70. U.S. CONST. art. I, $\S 8, \mathrm{cl} .8$ (empowering Congress to secure to "Authors and Inventors the exclusive Right to their respective Writings and Discoveries"). 
Privilege of the Writ of Habeas Corpus"-and we should note that Rawle insisted that this and only this provision of Section 9 bound states. ${ }^{71}$ The Barron contrarians, then, denied that Section 9 was, as a general matter, truly "in the nature of a bill of rights."72 The first ten amendments, by contrast, were commonly described as such, and used the words "rights" and "freedoms" over and over-in no less than six different amendments. ${ }^{73}$ Unlike Section 9, then, the Bill truly declared rights that, according to contrarian ideology, bound all governments.

This way of thinking would have been deeply foreign to many of the men who had clamored for a Bill of Rights in the 1780's. The word "right" had no talismanic natural law significance; after all, many sought a Bill to confer-or declare-states' rights, once again revealing the original intertwining of rights and structure. ${ }^{74}$ So too, a feudal inheritance made it quite easy for many in the 1780's to intuit the idea Hohfeld would resurrect and refine after the heyday of natural rights talk in the mid-nineteenth century. Particularistic customs, charters, and the like gave distinct persons or entities distinct rights or privileges against distinct entities, but not others. ${ }^{75}$ Indeed, much of the Declaration of Independence and its predecessor petitions can be seen as backward-looking invocations of particularistic rules and customs.

The Barron contrarians, by contrast, emphasized the Declaration's more sweeping and universalizing Enlightenment rhetoric of "self-evident truths" and the "inalienable rights" of "all men." Contrarians self-consciously sought to distill the pure essence of rights-citizen rights, not state rights-that had been blended with structural issues in the Bill. ${ }^{76}$ As an interpretation of the original Bill, their view had huge problems, but as a vision of the future Bill, it deserves our careful consideration-for it was a view that would ultimately prevail in the language and logic of the Fourteenth Amendment. ${ }^{77}$

The clearest contrarian articulations occurred in conscious reaction to Barron itself. In the 1840 case of Holmes v. Jennison, former New Hampshire Governor C.P. Van Ness politely but boldly attacked Barron in his oral argument before the Supreme Court: "With the utmost deference I beg leave to

71. RAWLE, supra note 48 , at 113.

72. Cf. supra text accompanying notes $27-28$.

73. U.S. CONST. amend. I "freedom" of speech and of the press; "right" to assemble and petition; "free" exercise of religion); id. amend. II ("right" to keep and bear arms); id. amend. IV ("right" against unreasonable searches and seizures); id. amend. VI ("right" to various procedural protections in criminal prosecutions); id. amend. VII ("right" to civil jury); id. amend. IX ("rights" retained by the people).

74. See Amar, supra note $t$, at 1203-04 and sources cited therein.

75. See Carol M. Rose, The Ancient Constitution vs. The Federalist Empire: Anti-Federalism From the Attack on "Monarchism" to Modern Localism, 84 Nw. U. L. REV. 74, 75-84 (1989).

76. See TENBROEK, supra note 64, at $90-91$ (contrarians "disregard[ed]" federalism in parsing the Constitution: "Once a mention of the rights [to be protected] was found, the rest was easy." (emphasis added)).

77. Cf. Strauder v. West Virginia, 100 U.S. 303, 307-08, 310 (1880) (self-consciously inferring "rights" and "immunities" from constitutional provisions worded as "prohibitions"); Ex parte Virginia, 100 U.S. 339, 345 (1880) (similar). 
observe, that in my humble judgment, an error was committed by the Court ...."78 After going out of his way to remind the Justices that the original amendments to the Constitution were "commonly called the bill of rights," he distinguished between certain provisions that were merely "limitations of power" and others that "are to be understood as declarations of rights." inherent in the people, and of which no power can legally deprive them," "principles which lie at the very foundation of civil liberty, and are most intimately connected with the dearest rights of the people[,] . . . [p]rinciples which ... . deserve to be diligently taught to our children, and to be written upon the posts of the houses, and upon the gates." ${ }^{\text {Th }}$ Though not clearly developed, here lay seeds for a kind of selective incorporation based on whether a particular clause of the Bill was a mere "limitation of power" or alternatively a "declaration of right."

Far more elaborate were various opinions of the Supreme Court of Georgia in the late 1840's and early 1850's, two of which were authored by Chief Justice Joseph Henry Lumpkin. In the first, Nunn v. Georgia, Lumpkin wrote that he was "aware" of contrary rulings (including, presumably Barron), but nevertheless invoked the Second Amendment to void a state statute. ${ }^{81}$ Lumpkin began by emphasizing English common law rights that preexisted state and federal constitutions. For him, state constitutions "confer no new rights on the people which did not belong to them before." federal Bill of Rights, "in declaring that the right of the people to keep and bear arms, should not be infringed, only reiterated a truth announced a century before, in the [English Bill of Rights] of 1689."83 Like Rawle and Van Ness before him, Lumpkin stressed the Bill's declaratory and didactic nature. The people, wrote Lumpkin, adopted the Bill "as beacon-lights to guide and control the action of [state] legislatures, as well as that of Congress. If a well-regulated militia is necessary to the security of the State of Georgia and of the United States, is it competent for the [Georgia] General Assembly to take away this security, by disarming the People?"84 Like Rawle, Lumpkin seemed to deny that the Tenth Amendment was a purely state rights provision, for he read it to imply that "the people" had certain rights in contradistinction to the "states." And in asking the question whether arms-bearing was "a right reserved to the

78. 39 U.S. (14 Pet.) 540, 555 (1840).

79. Id. at 555-56.

80. Id. at 556-57. The last reference is of course Biblical, see Deuteronomy 6:6-9, and is only one of countless examples of the strong religious emphasis among contrarians and, later, Reconstructors. It is also a reminder that, like scripture, a bill of rights was written to be memorized and internalized by ordinary citizens. See Amar supra note $\dagger$, at 1208-09.

81. Nunn v. Georgia, $1 \mathrm{Ga} .243,250$ (1846).

82. Id. at 249.

83. Id.

84. Id. at $250-51$ (emphasis omitted). 
States or to themselves [i.e., the people]," ${ }^{85}$ Lumpkin found dispositive the language of the Second Amendment declaring a "right of the people."

Lumpkin reiterated and elaborated these themes in the 1852 case of Campbell $v$. Georgia, in which he explicitly cited Barron but once again held that the Bill's provisions generally bound states. ${ }^{86}$ Though he did not "stop to examine" Barron in detail, ${ }^{87}$ Lumpkin wisely avoided the expressio unius argument that Marshall had demolished and tried to outflank Marshall's historical narrative by widening the time frame. Once again, he began not with the framing of the federal Bill of Rights but with the ancient landmarks of the common law: "Magna Charta - the Petition of Right-the [English] Bill of Rights [of 1689] -and more especially, ... the Act of Settlement, in Britain." ${ }^{88}$ By emphasizing the common law background, Lumpkin could plausibly portray the federal Bill of Rights as added "out of abundant caution" to clarify preexisting legal rights. ${ }^{89}$ And this declaratory purpose, Lumpkin argued, clearly justified application of the Bill to states, as emphasized by his own italics: The Bill of Rights' purpose "was to declare to the world the fixed and unalterable determination of our people, that these invaluable rights . . . should never be disturbed by any government." The Bill was "our American Magna Charta." $" 90$

Lumpkin then began a discussion about whether unenumerated "natural rights of man" "independently of [rights specified] in written constitutions" could ever limit American legislatures, quoting and paraphrasing broad natural law passages from various U.S. Supreme Court cases. ${ }^{91}$ For reasons of institutional competence, Lumpkin did not "intend to put our opinion . . . upon this foundation, however solid it may be." ${ }^{\text {"92 }}$ Given that "our ideas of natural justice are vague and uncertain," perhaps a wide-open hunt for natural law would allow judges too much discretion - freedom to make, rather than find, natural law. ${ }^{93}$ "But," Lumpkin argued, "as to questions arising under these amendments, there is nothing indefinite. The people of the several States, by adopting these amendments, have defined accurately and recorded permanently their opinion, as to the great principles which they embrace ...."94 If this last argument

85. Id. at 250.

86. Campbell v. State, $11 \mathrm{Ga} 353$ (1852).

87. Id. at 369.

88. Id. at 365 . This catalogue appears to be taken directly from Blackstone. See infra text accompanying notes 126-28.

89. $11 \mathrm{Ga}$ at 365 .

90. Id. at 368 .

91. Id. at 369-70 (citing, inter alia, Fletcher v. Peck, 10 U.S. (6 Cranch) 87 (1810); Terrett v. Taylor, 13 U.S. (9 Cranch) 43 (1815); Green v. Biddle, 21 U.S. (8 Wheat.) 1 (1823)).

92. $11 \mathrm{Ga}$. at 371 .

93. Id.

94. Id. at 372 (emphasis added). Beyond Nunn and Campbell, the most important Georgia Supreme Court decisions in a contrarian vein involved application of the Fifth Amendment just compensation clause-the same clause at issue in Barron-against various Georgia laws. In Young v. McKenzie, $3 \mathrm{Ga}$. 31 (1847), the court, per Justice Hiram Warner, stated that the clause did no "more than declare a great 
looks vaguely familiar, it should. A century later another Southern judge-one Hugo LaFayette Black-would make a strikingly similar argument on behalf of his crusade to "incorporate" the Bill of Rights against the states.

\section{The Contrarian Context}

In their belief that Barron was wrongly decided, men like Van Ness and Lumpkin found themselves in a distinct minority among antebellum lawyers; but time was on their side. As the years wore on, changes were occurring in America that made major premises of the original Bill of Rights-premises faithfully followed in Barron-more and more problematic. Regardless of whether the original Bill was intended to apply against states, it became increasingly plausible to think that the Constitution should be amended to overrule Barron.

\section{Technology, Geography, and Ideology}

Consider first the broad technological changes in the first half of the nineteenth century. In the 1780's, Anti-Federalists had feared that national lawmakers would literally be too far removed from their constituents for mutual confidence to develop; congressmen would lack current information about constituent desires, and citizens would find it difficult to monitor their federal representatives. ${ }^{95}$ Hence, special constitutional restrictions on Congress made sense. But over the next eighty years, improved roads, new canals, and the invention of the railroad and the telegraph revolutionized transportation and communication, diminishing the feeling that national lawmakers were qualitatively more distant than state ones. Nor was the Congress of the mid-nineteenth century drastically smaller, and thus more subject to cabal and intrigue, than its state counterparts. The specter of a thirteen-man House of Representatives that Patrick Henry had conjured up in $1788^{96}$ seemed rather fanciful in 1859 ,

common law principle, applicable to all govemments, both State and Federal, which has existed from the time of Magna Charta." Id. at 41 (emphasis altered). See also id. at 44 (explicitly noting congressional preamble to federal Bill of Rights describing its provisions as "declaratory and restrictive clauses" (emphasis added by the court)). In Parham v. The Justices, $9 \mathrm{Ga}$. 341 (1851), Justice Eugenius Nisbet, on behalf of the court, invoked Magna Charta, the common law, Blackstone, the "ablest" academic commentators, opinions from several sister state courts, the language of several sister state constitutions, and, finally, the language of the federal Fifth Amendment. Id. at 349-51. In support of the last item, Nisbet wrote:

The Constitution of the United States upon this point, I know, has been held to be a restraint upon federal legisiation alone, and not to apply to the States. If that be admitted, yet it is still authority, most significant, for the application of the rule in the States. It is the declaration of the [judicial] opinion of the American people ... [and] a solemn avowal, by the people, that a power to take private property, without compensation, does not belong to any government." Id. at 351 (emphasis added).

95. See Amar, supra note $t$, at 1137-45.

96. See 3 ELLIOT's DEBATES, supra note 30, at 46; Amar, supra note $\dagger$, at 1140-41. 
when the size of the lower House had swelled to over 200 members-a number that made several state lower houses look rather small by comparison.

Geographic expansion also worked ideological inversions. In the 1780's, state governments had distinguished pedigrees going back to their respective colonial foundings, while the national government proposed by Madison and his fellow Federalists was something altogether novel. ${ }^{97}$ Prudence, if nothing else, dictated special skepticism about the new government, and special restrictions on it. By contrast, in the antebellum era, the federal government was well established, while various new states were springing to life as the nation pushed inexorably westward (an expansion spurred on, of course, by the technological advances we have just noted). But these new states gave rise to a puzzle: why should a territorial legislature, as an agent of Congress, be bound by all the restrictions of the federal Bill of Rights when state governments were not? Indeed, did it make any sense that immediately upon admission to statehood, a territory could ignore all sorts of salutary restraints in the Bill that had previously applied to it? Congressman John Bingham apparently thought not, for in considering Oregon's proposed admission to the Union in 1859, he declared:

In my judgment, sir, this constitution, framed by the people of Oregon, is repugnant to the Federal Constitution, and violative of the rights of citizens of the United States. I know, sir, that some gentlemen have a short and easy method of disposing of such objections as these, by assuming that the people of the State, after admission, may, by changing their constitution, insert therein every objectionable feature which, before admission, they were constrained to omit . . . . [But I deny] that the States are not limited by the Constitution of the United States, in respect of the personal or political rights of citizens of the United States ....

$\cdots$

... [W]henever the Constitution guaranties to its citizens a right, either natural or conventional, such guarantee is in itself a limitation upon the States .... 98

As we shall see, Bingham would later write this philosophy into Section One of the Fourteenth Amendment.

97. See, e.g., 1 THE RECORDS OF THE FEDERAL CONVENTION OF 1787, at 250, 338, 439 (Max Farrand ed., rev. ed. 1937) (remarks of John Lansing and Luther Martin); THE ANTI-FEDERALISTS 93, 124, 133, 171, 185, 240-41, 251, 254 (Cecelia M. Kenyon ed., Northeastern University Press 1985) (1966) (collecting objections to novelty of proposed Constitution from various Anti-Federalists). For Publius' attempt to blunt this critique, see THE FEDERALIST NO. 14, at 10405 (James Madison).

98. CONG. GLOBE, 35th Cong., 2d Sess. 982 (1859); see also CONG. GLOBE, 37th Cong., 2d Sess. 1640 (1862) (remarks of John Bingham, invoking the congressional "act for the admission of [Bingham's home state of] Ohio on the condition of perpetual freedom to all law-abiding men within her limits"); Howard Jay Graham, The "Conspiracy Theory" of the Fourteenth Amendment, 47 YALE L.J. 371, 395 n.84 (1938) (discussing this aspect of Bingham's thought as possibly influenced by congressional statutes conditioning admission of new states on compliance with due process and other guarantees). 
Consider next the libertarian track record of central versus local government. The American Revolution had featured local colonies fighting an imperial center in the name of both freedom and federalism. In light of their experience with imperial arrogance and oppression on the one hand, and the heroic roles played by local governments in resisting oppression on the other, many Americans in the 1780's associated a strong central government with tyranny and a strong state government with freedom. This association was of course strengthened by the events in the following decade, with the Virginia and Kentucky legislatures leading the charge against the federal Sedition Act. But in the ensuing decades, it would be hard to argue that the central government acted qualitatively more repressively than local ones. Why, then, the Barron double standard?

In some situations, the very line separating state and federal government began to blur. We have already seen in passing the tricky double jeopardy questions raised when both state and federal governments prosecuted a defendant for the same underlying conduct; but the free press clause posed an analogous puzzle that received far more public attention. In the 1830's, various states sought to ban "incendiary" publications and wanted federal officials to cooperate by closing the mails to such publications. Would such censorship constitute federal action violative of the First Amendment or state action beyond the Amendment's scope? ?9 $^{99}$

To an increasing number of friends of free speech, this knotty question, even if answerable, seemed to miss the point. Why should the right of citizens to publish controversial views turn on fine legal distinctions about which government's hands had really wielded the censor's red pen? If "incendiary" publications dealt with national political issues, why was a state tax on national speech any more constitutional than a state tax on the national bank? ${ }^{100}$ And even if publications addressed only local matters, did not the Constitution's requirement of republican government ${ }^{101}$ and its overarching principle of popular sovereignty oblige state governments to allow citizens the greatest latitude in the expression of political opinions? ${ }^{102}$ As to speech and press, then, a growing number of Americans were coming to appreciate the wisdom of Madison's failed "No State shall" amendment, which had tried to make clear

99. See WILLIAM M. WIECEK, THE SOURCES OF ANTISLAVERY CONSTITUTIONALISM IN AMERICA, 17601848, at 172-82 (1977); David Yassky, Eras of the First Amendment, 91 COLUM. L. REV. 1699, 1713-17 (1991). At almost the same time, a similar blurring of the state/federal line was at work in various slave rendition cases under Congress' Fugitive Slave Act of 1793, which involved state magistrates enforcing federal laws and raised intricate questions of state incorporation of federal law. See, e.g., SALMON P. CHASE, SPEECH IN THE CASE OF THE COLORED WOMAN MATILDA 23-25, 32-36 (Cincinnati, Pugh \& Dodd 1837).

100. Cf. McCulloch v. Maryland, 17 U.S. (4 Wheat.) 316 (1819); ChARLES L. BLACK, JR., STRUCTURE AND RELATIONSHIP IN CONSTITUTIONAL LAW 33-50 (1969).

101. U.S. CONST. art. IV, $\$ 4$ (guaranteeing "a Republican Form of Government" to "every State in this Union").

102. See generally ALEXANDER MEIKLEJOHN, POLITICAL FREEDOM: THE CONSTITUTIONAL POWERS OF THE PEOPLE (1960); Alexander Meiklejohn, The First Amendment is an Absolute, 1961 SUP. CT. REV. 245. 
that state officials should be no more free to censor than their federal counterparts.

Madison, of course, in both The Federalist No. 10 and in the First Congress had argued that state governments were more likely to tyrannize minorities, ${ }^{103}$ but as we saw earlier, the Senate rejected his original "No State shall" amendment. Part of the reason was that in the 1780's, "liberty" was still centrally understood as public liberty of democratic self-government-majoritarian liberty rather than liberty against popular majorities. ${ }^{104}$ Madison thought otherwise, but was a man ahead of his time. By the Civil War era, the general intellectual tide was shifting, as reflected in the publication in 1859 of John Stuart Mill's classic tract, On Liberty-on individual liberty.

\section{Slavery}

But surely, to say all this about antebellum America is to rehearse Hamlet without the Prince, for we have yet to confront the issue that shattered the founders' Union: slavery. As important as canals, railroads, and telegraph lines were, none of these innovations was more significant than the cotton gin, which killed any chance that slavery might prove so unprofitable that it could be abolished without great economic dislocation. And no issues of geographic expansion posed by the new territories were as explosive as slavery and race-the subjects, indeed, of Bingham's specific objections to the Oregon Constitution. Nor did any issue place the libertarian track record of federal versus state governments in stronger light than did slavery. And on this question, states did not sparkle. Slavery was almost exclusively a creature of state law. To be sure, the federal government had supported the slave system with fugitive slave laws and other policies, including a postal system that helped exclude abolitionist mailings from distribution in the South. (These mailings, of course, were the main targets of the 1830's bans on "incendiary" literature.) Yet a major platform of the Free Soil and Republican Parties in the 1840's and 1850 's was that the Constitution forbade any federal involvement with slavery: freedom was national; slavery, local-hence the popular slogan "Freedom National," a slogan that would have sounded quite odd in the 1780's and 1790 's. ${ }^{105}$ Finally, of course, the abject plight of blacks dramatized the danger to liberty posed by even majoritarian government.

103. See Amar, supra note $t$, at $1146-49$.

104. See GORDON S. WOOD, THE CREATION OF THE AMERICAN REPUBLIC, 1776-1787, at 24-25, 60-61, 362 (1969).

105. See National PaRTY Platforms 1840-1968, at 5 (Kirk H. Porter \& Donald B. Johnson eds., 4th ed. 1970) (Liberty Platform of 1844, $\$ 10,11$ ); id. at 13-14 (Free Soil Platform of 1848, passim); id. at 18 (Free Democratic Platform of 1852, §§ IV, VII); id. at 27 (Republican Platform of 1856, para. 3); $i d$. at 32 (Republican Platform of $1860, \S \S 5,8$ ). See generally ERIC FONER, FREE SOI, FREE LABOR, FREE MEN 73-102 (1970); HAROLD M. HYMAN \& WILLIAM M. WIECEK, EQUAL JUSTICE UNDER LAW 17-18, 92-93, 170 (1982). 
The structural imperatives of the peculiar institution led slave states to violate virtually every "right" and "freedom" declared in the Bill-not just rights and freedoms of slaves, but of free men and women too. ${ }^{106}$ Simply put, slavery required repression. Speech and writing critical of slavery-even if plainly religious or political in inspiration-was incendiary and had to be suppressed in Southern states, lest slaves overhear and get ideas. ${ }^{107}$ Teaching slaves to read (even The Bible) was a criminal offense punished severely in some states. ${ }^{108}$ In a society that saw itself under siege after Nat Turner's rebellion, ${ }^{109}$ access to firearms had to be strictly restricted, especially to free blacks. ${ }^{110}$ The problem of fugitive slaves created further pressures on civil liberties that made life treacherous indeed for free blacks. Typically, all Southern blacks were legally presumed to be slaves, subject to arbitrary "seizures" of their "persons," triable as fugitives without juries in proceedings lacking basic rudiments of due process and, if adjudged to be escaped slaves, subject to great cruelty as a warning to others. ${ }^{111}$

To counter this regime of repression, abolitionist and antislavery lawyers could not simply rely on positive law, for slavery itself was deeply embedded in positive law. Beginning in the 1830's, abolitionist lawyers developed increasingly elaborate theories of natural rights, individual liberty, and higher

106. See, e.g., MiCHAEL KeNT CURTIS, No STATE SHALl ABRIDGE: THE FOURTEENTH AMENDMENT AND THE BILL OF RIGHTS 36 (1986); WILLIAM GOODELL, THE AMERICAN SLAVE CODE IN THEORY AND PRACTICE 372-84 (Negro University Press 1968) (1853); HYMAN \& WIECEK, supra note 105, at 15; TENBROEK, supra note 64, at 38-39, 125-26.

107. See CURTIS, supra note 106, at 23, 30-38; KENNETH M. STAMPP, THE PECULIAR INSTITUTION 211-12 (1956); Alfred Avins, Incorporation of the Bill of Rights: The Crosskey-Fairman Debates Revisited, 6 HARV. J. ON LEGIS. 1, 17-26 (1968).

108. See CONG. GLOBE, 39th Cong., 1st Sess. 1013 (1866) (remarks of Rep. Tobias Plants); STAMPP, supra note 107, at 208, 211; TENBROEK, supra note 64, at 124-25; Avins, supra note 107, at 17.

109. See STAMPP, supra note 107 , at $132-40$.

110. See STEPHEN P. HALBROOK, THAT EVERY MAN BE ARMED 96-106 (1984); Robert J. Cottrol \& Raymond T. Diamond, The Second Amendment: Towards an Afro-Americanist Reconsideration, 80 GEO. L.J. 309, 333-38 (1991).

111. See STAMPP, supra note 107 , at $153,188-91,193-94,212,215-17$; THOMAS D. MORRIS, FREE MEN ALL (1974). 
law-theories far more compatible with a "declaratory" reading of the federal Bill than with Barron's technical legalism. ${ }^{112}$

The fabric of the original Bill of Rights, interweaving freedom and federalism, was unraveling under the strain of slavery. And once the Civil War came, Barron seemed plainly anachronistic. For if the years leading up to the Revolutionary War had dramatized the special danger of central tyranny, leading to Barron's Bill, the Civil War era demonstrated that states required constitutional restraints as well.

The abolition of slavery in the Thirteenth Amendment-the first federal constitutional amendment to restrict state law-was obviously the place to start. But was it enough? When the Thirty-ninth Congress convened in December 1865 , various unrepentant Southern governments were in the process of resurrecting slavery de facto through the infamous Black Codes. As with the slavery system itself, the new codes would invariably require systematic state abridgments of the core rights and freedoms in the Bill of Rights. These abridgments would of course hit blacks the hardest, but the resurrection of a caste system would also require repression of any whites who might question the codes or harbor sympathy for blacks. ${ }^{113}$ In response, the Thirty-ninth Congress drafted Section One of the Fourteenth Amendment.

112. For a nice discussion of the influence of this abolitionist theory on the Reconstruction Republicans of the 39th Congress, see CuRTIS, supra note 106, at 26-56.

In light of the deep resonance between the declaratory view of the federal Bill and abolitionism, it is of course ironic that perhaps the leading judicial exponent of the declaratory theory in the 1840's and 1850's was the emphatically pro-slavery Georgia Supreme Court. For a concrete illustration of this irony, see State ex rel. Tucker v. Lavinia, $25 \mathrm{Ga}$. 311, 313-14 (1858) (Lumpkin, C.J.) (extending benefit of "great principle of the common law" against double jeopardy to "slaves and free persons of color as well as to white persons"). If free persons of color were entitled to the great common law principle of double jeopardy, why not also to Nunn's great common law principle of the right to keep and bear arms?

Its association with a pro-slavery court made the Nunn/Campbell line of cases a far less likely source of direct influence on Republicans in the 39th Congress than the abolitionist sources discussed by Curtis. Nevertheless, this line of cases is extremely important in proving that the declaratory reading of the federal Bill was not merely a fringe theory of a small group of abolitionist extremists, but rather was appealing to many thoughtful lawyers steeped in the common law method-and in particular, to judges attentive to issues of judicial role and self-conscious about the need to guide and constrain judicial discretion.

113. See, e.g., CONG. GLOBE, 39th Cong., 1st Sess. 1065 (1866) (remarks of Rep. John Bingham) (stressing need to protect "thousands of loyal white citizens" in the South from property confiscations and other repressive measures); Charles Fairman, Does The Fourteenth Amendment Incorporate the Bill of Rights?, 2 STAN. L. REV. 5, 90 (1949) (quoting October 1866 speech of Vermont Governor Paul Dillingham on need to ratify Fourteenth Amendment to "secure to the original Union men of the South equal rights and impartial liberty"); The Slaughter-House Cases, 83 U.S. (16 Wall.) 36, 123 (1873) (Bradley, J., dissenting) ("The mischief to be remedied was not merely slavery . . . [but also] that intolerance of free speech and free discussion which often rendered life and property insecure, and led to much unequal legislation."); Ex parte Virginia, 100 U.S. 339, 364-65 (1880) (Field, J., dissenting) (discussing importance of protecting various Northerners and Unionists in South). See generally S. ExEC. Doc. No. 2, 39th Cong., 1st Sess. (1865) (report of Carl Schurz) (detailing need to protect white Unionists and Yankees in the South); CHESTER JAMES ANTIEAU, THE ORIGINAL UNDERSTANDING OF THE FOURTEENTH AMENDMENT 24-25(1981) (collecting similar quotations). 


\section{THE EASY CASE FOR INCORPORATION}

\section{A. The Text of the Fourteenth Amendment}

No State shall make or enforce any law which shall abridge the privileges or immunities of citizens of the United States; nor shall any State deprive any person of life, liberty, or property, without due process of law; nor deny to any person within its jurisdiction the equal protection of the laws.

So reads the second sentence of the Fourteenth Amendment-a sentence around which the entire incorporation debate has swirled. For however much they disagree about everything else, all the participants in the incorporation debate have found common ground in the belief that the answer to the debate lies in these words. In light of the stakes involved, and the brevity of the text, we would do well to weigh each word with care. And when we do, we shall see that the textual argument for incorporation - of a certain sort-is remarkably straightforward.

\section{1. "No State shall ..."}

For those in the incorporation camp, the key sentence gets off to a great start. Anyone paying the slightest attention to constitutional text would find the same phrase in Article I, Section 10 imposing various limitations on states, including several key rights designed principally for the benefit of in-state residents: "No State shall . . p pass any Bill of Attainder, ex post facto Law, or Law impairing the Obligation of Contracts, or grant any Title of Nobility." In 1810, Chief Justice Marshall's opinion for the Court in Fletcher v. Peck declared that the language of Article I, Section 10 "may be deemed a bill of rights for the people of each state" Court in 1853 and again in 1866, the same year in which the Fourteenth Amendment was drafted. ${ }^{115}$ Of course, the Court did not mean to suggest that the catalogue of Section 10 rights was identical to that set out in the first ten amendments - otherwise the entire Barron and incorporation debates would be moot. But the language of Fletcher and its progeny does confirm the rhetorical resonance between the phrase "No State shall" and the idea of a federally enforceable "bill of rights" against state governments. Madison had intuited this resonance a dozen years before Fletcher when he proposed to include in his "Bill of Rights" an amendment that "No State shall" abridge various rights of religion, expression, and jury trial.

114. 10 U.S. (6 Cranch) 87,138 (1810).

115. See Piqua Branch of the State Bank v. Knoop, 57 U.S. (16 How.) 369, 385, 392 (1853); Cummings v. Missouri, 71 U.S. (5 Wall.) 277, 322, 325 (1866). 
Far more dramatic evidence of this resonance comes from Barron, where a unanimous Supreme Court stated that, had the framers of the original Bill of Rights meant to impose its rules on states, they would have used the Article I, Section 10 phrase "No State shall" or some reasonable facsimile thereof. But if the framers of the original Bill were entitled to rely on rules of construction implicit in the Philadelphia Constitution and made explicit by Publius in The Federalist No. 83, surely the framers of the Fourteenth Amendment were entitled to rely on the authoritative language of Barron itself. The Supreme Court Justices in Barron asked for "Simon Says" language, and that's exactly what the Fourteenth Amendment gave them.

Earlier drafts of the key sentence had omitted the words "No State shall" in favor of other formulations, but as Congressman John Bingham explained several years after the Amendment's adoption, he rewrote Section One in response to and in reliance upon Barron:

In reexamining that case of Barron, Mr. Speaker, after my struggle in the House in February $1866, \ldots$ I noted and apprehended as I never did before, certain words in that opinion of Marshall. Referring to the first eight articles of amendments to the Constitution of the United States, the Chief Justice said: "Had the framers of these amendments intended them to be limitations on the powers of the State governments they would have imitated the framers of the original Constitution, and have expressed that intention." Barron $v$ s. The Mayor, \&c., 7 Peters, 250.

Acting upon this suggestion I did imitate the framers of the original Constitution. As they had said "no State shall emit bills of credit, pass any bill of attainder, ex post facto law, or law impairing the obligations of contracts;" imitating their example and imitating it to the letter, I prepared the provision of the first section of the fourteenth amendment as it stands in the Constitution.....$^{116}$

2. “. . make or enforce any law which shall abridge ..."

As the key sentence rolls on, the incorporation reading gains steam. Various critical words of the next phrase-_make," "any," "law," and "abridge,"-call to mind the precisely parallel language in parallel sequence of the First Amendment-"make," "no," "law," and "abridging."117 There are only three significant differences here.

First, the Fourteenth Amendment imposes a prohibition on states, whereas the First explicitly limits "Congress." But this is of course exactly the point of incorporation. And what better way to make clear that even rights and freedoms in the original Bill of Rights that explicitly limited "Congress" should hereafter

116. CoNG. GLOBE, $42 \mathrm{~d}$ Cong., Ist Sess. 84 app. (1871) (emphasis altered).

117. U.S. CoNsT. amend. I ("Congress shall make no law . . . abridging . . . ."). 
apply against states than by cloning the language of the First Amendment? (The word "abridge" in the Fourteenth Amendment is especially revealing, for nowhere outside the First Amendment had this word appeared in the Constitution before 1866.) Thus, the Fourteenth Amendment announced its intention to go beyond the expressio unius arguments of William Rawle and John Barron, as had Lumpkin in Campbell, where the Georgia Chief Justice explicitly included First Amendment freedoms in his catalogue of rights binding states. ${ }^{118}$

Second, the Fourteenth Amendment uses the word "any" where the First uses "no," but here again, there is an obvious reason. Following the "Simon Says" rules of Barron "to the letter," the Fourteenth uses negative phrasing ("No State shall ....") where the First used affirmative ("Congress shall . .."). The substitution of "any" for "no" simply balances out the initial inversion.

Finally, the Fourteenth Amendment speaks of law "enforce[ment]" as well as law making. Once again, this makes perfect sense if its purpose was to incorporate the rights and freedoms of the original Bill. Many of the Bill's provisions, especially those in Amendments V-VIII, dealt centrally with the enforcement of laws by executive and judicial officers. However suggestive the tracking of the First Amendment may be, there is no suggestion thus far that only the First Amendment is to be incorporated.

\section{3. ". . the privileges or immunities ..."}

Of course, my last sentence was a bit of a cheat; there is no suggestion "thus far" that only the First Amendment is to be incorporated because it is not yet clear what rights shall not be "abridge[d]" by states. The words we have considered so far are wonderfully suggestive-exactly what one would expect if incorporation were a goal of the Fourteenth Amendment-but hardly definitive. If the Fourteenth Amendment had stated that "No State shall make any law abridging the right to spit on sidewalks," no one could argue with a straight face for incorporation of the federal Bill of Rights.

Happily, the final words of the first clause are very different, and once again exactly what one would expect if incorporation of a certain sort-which I shall soon elaborate-were intended. Consider first the words "privileges" and "immunities." Now, these exact words do not appear in the Bill of Rights, but the words "right[s]" and "freedom[s]" speckle the Bill. ${ }^{119}$ The plain meanings of these four words are virtually synonymous; indeed, the Oxford English Dictionary definition of "privilege" includes the word "right"; and of "immunity," "freedom." 120 What could be more common today than to speak of the

118. Campbell v. State, $11 \mathrm{Ga} .353,366,373$ (1852).

119. See supra note 73 and accompanying text.

120. 12 OXFORD ENGLISH DICTIONARY 522 (2d ed. 1989) (defining "privilege" as a "right, advantage, or immunity"); 7 id. at 691 (defining "immunity" as "freedom from liability to taxation, jurisdiction, etc."). 
"privilege" against compelled self-incrimination, or the "immunity" from double prosecution? Nor is modern usage here any different from that of the eighteenth and nineteenth centuries. As Michael Kent Curtis observes in his illuminating and powerfully researched book on incorporation, the "words rights, liberties, privileges, and immunities, seem to have been used interchangeably." pick only one eighteenth-century example with obvious implications for the incorporation debate, the entitlements to civil and criminal juries, labeled in the Sixth and Seventh Amendments as "right[s]," were described by the 1775 Declaration of the Causes and Necessity of Taking Up Arms as the "inestimable privilege of trial by jury."122 A couple of generations later, Circuit Justice William Johnson described a congressional bill of 1822 as "in nature of a bill of rights, and of privileges, and immunities" of inhabitants of the Florida territory. ${ }^{123}$ Among the rights listed in the bill were "freedom of religious opinions;" "the benefit of the writ of habeas corpus;" and protections against "excessive bail," "cruel and unusual punishments," and confiscation without "just compensation"-all phrased almost identically with their federal Bill of Rights counterparts. ${ }^{124}$ Only weeks before adopting the Fourteenth Amendment, Congress passed the Civil Rights Act of 1866, widely seen as the statutory precursor of Section One. In draft, the Act spoke of "civil rights and immunities," leading its sponsor to play the role of law dictionary: "What is an immunity? Simply "freedom or exemption from obligation . . .."125

We have already noted that most American lawyers began their legal education with Blackstone and the common law. When we turn to Blackstone, we find the words "privileges" and "immunities" used to describe various entitlements embodied in the landmark English "Charters of liberty" of Magna Charta, the Petition of Right, the Habeas Corpus Act, the English Bill of Rights of 1689 , and the Act of Settlement of $1700 .{ }^{126}$ As we have seen, these English documents were the fountainhead of the common law, and the widely understood source of many particular rights that later appeared in the federal Bill, sometimes in identical language. ${ }^{127}$ After invoking Blackstone and the

121. CURTIS, supra note 106, at 64-65; see also ANTIEAU, supra note 113 , at 38 ("The American generations that ratified the Constitution and, Jater, the Fourteenth Amendment used the terms, 'rights,' 'liberties,' 'privileges,' and 'immunities' as virtual synonyms.").

122. Second Continental Congress, Declaration of the CaUses and NeCEssity of TAKNG UP ARMS, para. 3 (1775), reprinted in 1 GREAT IsSUES IN AMERICAN HISTORY 46, 49 (Richard B. Hofstadter ed., 1958).

123. American Ins. Co. v. Canter, 26 U.S. (1 Pet.) 511, 517 (1828) (reprinting circuit opinion of Justice Johnson). (1822).

124. An Act for the Establishment of a Territorial Government in Florida, ch. 10, 3 Stat. 654, 658

125. CONG. GLOBE, 39th Cong., 1st Sess. 1117 (1866) (remarks of Rep. James Wilson).

126. 1 WILLIAM BLACKSTONE, COMMENTARIES *127-45.

127. See, e.g., Act For Declaring the Rights and Liberties of the Subject, and Settling the Succession of the Crown (Bill of Rights), 1689, 1 W. \& M., ch. 10 (Eng.) ("excessive bail ought not to be required, nor excessive fines imposed; nor cruel and unusual punishments inflicted"). The language of the Eighth Amendment substitutes "shall not be" for "ought not to be," but is otherwise identical. 
above-listed landmarks, Chief Justice Lumplin's opinion in Campbell unsurprisingly described various rights in the federal Bill as "privileges"-including the right at issue in Campbell itself, the right to be confronted with witnesses. ${ }^{128}$ Lumpkin's ideas about Barron may have been unorthodox in 1852, but his language was utterly conventional; that same decade, the Supreme Court in Dred Scott labeled the entitlements in the federal Bill "rights and privileges of the citizen." 129

\section{4. ". . of citizens of the United States;"}

But even once we recognize that various "rights" and "freedoms" in the Bill are in every respect and for every purpose "privileges" and "immunities," there remains one final textual stumbling block. Can we really say that the Bill's "rights" and "freedoms" are truly privileges and immunities of "citizens of the United States?"

Of course we can. In ordinary, everyday language we often speak of the United States Constitution and Bill of Rights as declaring and defining rights of Americans as Americans. Surely our Constitution is not centrally about declaring, say, the rights of Frenchmen qua Frenchmen, or the Chinese qua Chinese. This ordinary, everyday understanding of the Constitution is emblazoned in the Preamble in words quite familiar to every generation of Americans since the Founding: "We the People of the United States, in Order to . . . secure the Blessings of Liberty to ourselves and our Posterity, do ordain and establish this Constitution for the United States."

This ordinary understanding is not in the least bit damaged by the technical objection to incorporation that Professor Louis Henkin has raised: "[T]he provisions of the Bill of Rights are not rights of citizens only but are enjoyed by non-citizens as well."130 Surely the fact that Americans may often extend many benefits of our Bill to, for example, resident aliens-for reasons of prudence, principle, or both-does not alter the basic fact that these rights are paradigmatically rights of and for American citizens. Indeed, others may enjoy certain benefits only insofar as they interact with American citizens-typically because they either live on soil governed by American citizens or do things with important effects on American citizens. Peripheral applications of the Bill should not obscure its core.

In any event, Henkin's technical objection collapses under the weight of its own anachronism. At the time of the Fourteenth Amendment, the best

128. Campbell v. State, $11 \mathrm{Ga} .353,373,374$ (1852).

129. Dred Scott v. Sandford, 60 U.S. (19 How.) 393, 449-50 (1857); see also Strauder v. West Virginia, 100 U.S. 303, 307-08, 310 (1880) (self-consciously equating "rights" and "immunities" in Fourteenth Amendment analysis); Ex parte Virginia, 100 U.S. 337, 345 (1880) (same). (1963).

130. Louis Henkin, "Selective Incorporation" In the Fourteenth Amendment, 73 YALE L.J. 74, 78 n.16 
known case on the scope of the Bill of Rights was none other than Dred Scott, which involved, among other issues, questions arising under the due process clause of the Fifth Amendment. Dred Scott declared the rights in the Bill to be not simply privileges, but "privileges of the citizen."131 This passage must be read in combination with the rest of the opinion, holding that because Dred Scott was not a citizen of the United States, he could not enjoy the privilege of diversity jurisdiction - or indeed, any of the "rights, and privileges, and immunities, guarantied by [the Constitution] to the citizen."132 The central meaning and logic of the opinion, which took pains to stress the words of the Preamble, ${ }^{133}$ was that the Constitution and the Bill of Rights were ordained and established by citizens of the United States, and for their benefit only.

Surely the framers of the Fourteenth Amendment were entitled to rely on Supreme Court interpretations in Dred Scott no less than in Barron, even as they sought to overrule them using "Simon Says" language suggested by the Court itself. ${ }^{134}$ And once again, it is clear that they did so rely. John Bingham, the main author of Section One, not only cited to Dred Scott in a speech before the House in early 1866, but quoted the following key language: "The words 'people of the United States' and 'citizens' are synonymous terms." ${ }^{135}$ In the Senate debates on the Fourteenth Amendment, the most extended and authoritative discussion of Section One came from Jacob Howard, and he too made plain that the language chosen was in response to Dred Scott: ${ }^{136}$

[I]t is a fact well worthy of attention that the course of decision in our courts and the present settled doctrine is, that all these immunities, privileges, rights thus guarantied ... or recognized by [the first eight amendments to the Constitution] are secured to the citizen solely as a citizen of the United States ....

Though many aspects of Dred Scott were highly offensive to members of the Thirty-ninth Congress, there was widespread support for the idea that the Bill of Rights was paradigmatically, even if not exclusively, a catalogue of privileges and immunities of "citizens." or startling. In both Nunn and Campbell, for example, Chief Justice Lumpkin had described the Bill of Rights as protecting "citizens."138

131. 60 U.S. at 449 (emphasis added).

132. Id. at 403.

133. Id. at $404,410-11$.

134. U.S. CONST. amend XIV, §1, cl. 1 ("All persons born or naturalized in the United States, and subject to the jurisdiction thereof, are citizens of the United States and of the State wherein they reside."). The first sentence of the Fourteenth Amendment consciously overruled Dred Scott's holding that blacks could never be "citizens."

135. CONG. GLOBE, 39th Cong., 1st Sess. 430 (1866) (quoting Dred Scott, 60 U.S. at 404).

136. Id. at 2765 .

137. See CURTIS, supra note 106 , at 103 .

138. Nunn v. Georgia, 1 Ga. 243, 250-51 (1846); Campbell v. State, 11 Ga. 353, 365 (1852). 


\section{5. "... nor shall any State deprive any person of life, liberty, or proper- ty, without due process of law;"}

Henkin's technical objection to incorporation does not merely dissolve; it boomerangs. By focusing our attention on Dred Scott and citizenship, Henkin unwittingly destroys another more familiar technical argument against incorporation. Many commentators (Raoul Berger most stridently) have claimed that if the privileges or immunities clause was designed to incorporate the rights and freedoms of the Bill, the clause would incorporate the Fifth Amendment's due process requirement and thereby render the Fourteenth Amendment's due process clause redundant. ${ }^{139}$ Berger's claim has loomed especially large because Justice Black, the leading judicial proponent of total incorporation, repeatedly ducked technical questions about the relationship between Section One's privileges or immunities and due process clauses. Instead, Black clung to the simple but vague formulation that the Fourteenth Amendment "as a whole" effected incorporation. ${ }^{140}$ Professor John Hart Ely, while generally supportive of incorporation, went even further in legitimizing Berger's technical objection by frankly conceding the redundancy point. ${ }^{141}$

But we can now see why Berger's technical objection collapses, like Henkin's, and for the same reason. By incorporating the rights of the Fifth Amendment, the privileges or immunities clause would, under the precedent of Dred Scott, have prevented states from depriving "citizens" of due process. Bingham, Howard, and company wanted to go even further by extending the benefits of state due process to aliens. But for this, a special clause was needed speaking of "persons," not "citizens." As Bingham explained his amendment on the floor of the House:

Is it not essential to the unity of the people that the citizens of each State shall be entitled to all the privileges and immunities of citizens [of the United States]? Is it not essential . . . that all persons, whether citizens or strangers, within this land, shall have equal protection in

139. Raoul Berger, Incorporation of the Bill of Rights in the Fourteenth Amendment: A Nine-Lived Cat, 42 OHIO ST. L.J. 435, 462 (1981) [hereinafter Berger, Incorporation]; RAOUL BERGER, THE FOURTEENTH AMENDMENT AND THE BILL OF RIGHTS 91-92 (1989) [hereinafter BERGER, FOURTEENTH AMENDMENT]; see also D.O. McGovney, Privileges or Immunities Clause, Fourteenth Amendment, 4 IOWA L. BULL. 219, 233 (1918); Stanley Morrison, Does the Fourteenth Amendment Incorporate the Bill of Rights?, 2 STAN. L. REV. 140, 159 (1949); cf. 1 DAVID CURRIE, THE CONSTITUTION IN THE SUPREME COURT 346 n.129 (1985) (due process clause "provides another argument against incorporation; it suggests that when the drafters of the amendment meant to make bill of rights provisions apply to the states, they said so").

140. See Adamson v. Califomia, 332 U.S. 46, 71-72, 74 (1947) (Black, J., dissenting); Duncan v. Louisiana, 391 U.S. 145, 166 n.1 (1968) (Black, J., concurring). Even before Black publicly announced his incorporation theory in Betts and Adamson, Justice Frankfurter, dissenting from an earlier Black opinion, anticipated and exploited Black's weak spot: "To say that the protection of freedom of speech of the First Amendment is absorbed by the Fourteenth does not say enough. Which one of the various limitations upon state power introduced by the Fourteenth Amendment absorbs the First?" Bridges v. California, 314 U.S. 252, 280-81 (1941) (Frankfurter, J., dissenting).

141. JOHN HART ELY, DEMOCRACY AND DISTRUST 27 (1980). 
every State in this Union in the rights of life and liberty and property? ${ }^{142}$

A few weeks later, Bingham reiterated the point in debates over the Civil Rights Act of 1866 when he proposed to substitute the word "inhabitant" for "citizen": "[A]re we not committing the terrible enormity of distinguishing here in the laws in respect to life, liberty, and property between the citizen and stranger within your gates .... Your Constitution says 'no person,' not 'no citizen,' 'shall be deprived of life, liberty, or property,' without due process of law."143

Howard's explanation to the Senate was identical. After explaining that the privileges and immunities of citizens of the United States included "the personal rights guarantied and secured by the first eight amendments of the Constitution"-a passage we shall return to later-he patiently elaborated that the subsequent clauses of Section One were needed to "disable a State from depriving not merely a citizen of the United States, but any person, whoever he may be, of life, liberty, or property without due process of law, or from denying to him the equal protection of the laws of the State." ${ }^{\text {"144 }}$ On this issue as well, the views of Bingham and Howard were widely shared by their Reconstruction colleagues. ${ }^{145}$ Indeed, Section One's distinction between the rights of citizens and those of aliens stretches back to its earliest draft in committee: "Congress shall have power to ... secure to all citizens ... the same political rights and privileges; and to all persons in every State equal protection in the enjoyment of life, liberty, and property." 146

But we have yet to feel the full zing of the anti-incorporation boomerangs, for just as Henkin's objection destroys Berger's, so Berger's emphasis on due process undermines Henkin. It would be odd to think that the words "due process" in the Fourteenth Amendment were intended to mean something very different than they did in the Fifth. Thus, when Andrew Jackson Rogers asked Section One's main architect, John Bingham, what he meant by "due process of law," Bingham tartly replied, "courts have settled that long ago, and the gentleman can go and read their decisions." 147 In 1866, the definitive statement of the meaning of the Fifth Amendment's due process clause was the

142. CONG. GLOBE, 39th Cong., 1st Sess. 1090 (1866).

143. Id. at 1292 .

144. Id. at 2765-66.

145. On the salience of the citizen/person distinction, see, e.g., $i d$. at 505, 1115, 2560, 2768-69, 2890 (remarks of Sen. Reverdy Johnson, Rep. James Wilson, and Sens. William Morris Stewart, Benjamin Wade, and Edgar Cowan); Ho Ah Kow v. Nunan, 12 F. Cas. 252, 256 (C.C.D. Cal. 1879) (No. 6546) (Field, Circuit J.); EARL M. MALTZ, CIVIL RIGHTS, THE CONSTITUTION, AND CONGRESS, 1863-1869, at 62-64, 97 (1990); NELSON, supra note 64, at 52-53; 2 CROSSKEY, supra note 29, at 1100-03, 1109-10; CURTIS, supra note 106, at 107; John Harrison, Reconstructing the Privileges or Immunities Clause, 101 YALE L.J. 1385 (1992).

146. BENIAMIN B. KENDRICK, THE JOURNAL OF THE JOINT COMMITTEE OF FIFTEEN ON RECONSTRUCTION 51 (1914). On the care taken by the Committee to distinguish between the rights of persons and those of citizens, see HORACE E. FLACK, THE ADOPTION OF THE FOURTEENTH AMENDMENT 63-64 (1908).

147. CONG. GLOBE, 39th Cong., 1st Sess. 1089 (1866). 
decade-old case of Murray's Lessee v. Hoboken Land \& Improvement Co. In that case, a unanimous Supreme Court said that procedural due process embodied-incorporated, if you will-all the other procedural rules laid down in "the constitution itself." 148 Rawle had said much the same thing in his treatise thirty years earlier. ${ }^{149}$ If, here too, the framers of the Fourteenth Amendment were entitled to rely on authoritative Supreme Court pronouncements (and it is hard to see why not), then the due process clause of the Fourteenth Amendment by itself embodied -incorporated - various procedural safeguards specified in Amendments V-VIII. That leaves only six amendments in the Bill-the first four and the last two-where the privileges or immunities clause has independent bite. ${ }^{150}$ Of these six, five explicitly speak of the rights of "the people"151 - a phrase that Dred Scott, John Bingham, and many other commentators understood as for many purposes synonymous with "citizens." For example, Senate rules circa 1866 did not permit foreigners to petition that body ${ }^{152}$ because petition was a right "of the people." The fit between the explicit rights of "the people" in the original Bill and those provisions where the privileges or immunities clause has independent bite may not be perfect, but surely it is close enough to explain why so many in 1866 would have naturally thought of the nonprocedural provisions of the original Bill as rights of citizens. ${ }^{153}$

148. 59 U.S. (18 How.) 272, 276-77 (1855); accord The Slaughter-House Cases, 83 U.S. (16 Wall.) 36, 118 (1873) (Bradley, J., dissenting).

149. RAWLE, supra note 48 , at 129 .

150. Thus, by dint of Murray's Lessee, aliens are entitled under the Fourteenth Amendment to all the procedural safeguards specified in the original Bill. In an otherwise thoughtful analysis of the incorporation debate, Professor Israel overlooks this, leading him to ask "why the framers of the Fourteenth Amendment would have desired to grant such privileges as jury trial and grand jury indictment only to citizens." Jerold H. Israel, Selective Incorporation: Revisited, 71 GEO. L.J. 253, 260 (1982). The short answer is that the framers of the Fourteenth Amendment intended exactly the opposite. The point is an especially important one because it was the only real "deficienc[y] in the textual support" for incorporation that Israel identified. Id.; see also Henkin, supra note 130, at 78 (overlooking Murray's Lessee in claiming that it is "clear" that "Court has not read 'due process of law' as a short-hand way of referring to specifics of the Bill of Rights").

151. U.S. CONST. amends. I, II, IV, IX, X.

152. See, e.g., Cong. GLOBE, 41st Cong., 2d Sess. 1536 (1870) (remarks of Sen. Samuel Pomeroy).

153. Some modern scholars have resisted the notion that the words of the privileges or immunities clause mean what they say in limiting their protection to "citizens." No less eminent a figure than John Hart Ely has suggested that the clause could instead be read as meaning that no state shall deny to any person the rights of citizens. Under this reading, the phrase "privileges or immunities of citizens" would "define the class of rights rather than limit the class of beneficiaries." ELY, supra note 141, at 25 . Ely offers a false dichotomy, for the original phrase is best read as doing both, defining the rights of Americans as Americans. Ely's reading does more than stretch the phrase's text; it blurs the legislative history of the Amendment and renders the due process clause an embarrassing redundancy that incorporationists must somehow explain away. (Ely notes the redundancy, then proceeds to sidestep it. Id. at 27.)

Now John Ely, of all people, should know better-as a textualist, as a believer in attention to legislative purpose, and as a friend of incorporation. Something else must be going on, and it's not hard to figure out what: like Justice Black before him, Ely is obviously concemed about state mistreatment of aliens. But the concern is largely misplaced. To begin with, aliens do enjoy against states the full benefit of all procedural rights of the original Bill by dint of the Fourteenth Amendment due process clause and Murray's Lessee, see supra note 150 . As to other rights, equal protection principles will require states to justify any discrimination between citizens and aliens. Finally, aliens may sometimes be able to present themselves as third party beneficiaries of citizen rights. Just as a doctor can invoke a female patient's abortion right, so aliens addressing American citizens about national issues should be protected by the 


\section{Beyond Mechanical Incorporation}

We have now come slowly, but I hope surely, to the deep truth at the core of Hugo Black's observation that "the words 'No State' shall make or enforce any law which shall abridge the privileges or immunities of citizens of the United States' seem . . . an eminently reasonable way of expressing the idea that henceforth the Bill of Rights shall apply to the States."154

The best objection to Black's claim is that other language could have been used that would have expressed the purpose more clearly. ${ }^{155}$ This objection does seem devastating to the particular brand of mechanical incorporation that Black's rhetoric at times appeared to suggest: that the privileges or immunities and due process clauses were simply terms of art referring to the first eight amendments in every jot and tittle, and to nothing else. If the key clauses of the Fourteenth Amendment meant Amendments I-VIII-no more, no less-why were the amendments not invoked by name? Why, indeed, use words like "privileges," and "immunities" which are only synonymous with, rather than identical to, the words of the first eight amendments themselves?

Black never offered satisfying answers to these questions, perhaps because the best answers require abandonment of mechanical incorporation. But for Black, part of the appeal of incorporation lay in its mechanical quality-its apparent ability to reduce judicial discretion by establishing an exact identity between the broad language of the Fourteenth Amendment and the seemingly more specific rules of Amendments I-VIII. ${ }^{156}$ The framers of the Fourteenth

citizens' right to a free press and freedom of speech-rights which of course go beyond freedom to print and to speak. To me, at least, that much was decided by the court of history's judgment against the Alien and Sedition Acts. "The essential point is not that the alien has a right to speak but that we citizens have a right to hear him." MEIKLEJOHN, supra note 102, at 53.

Gaps between citizen and alien rights against states will remain-as some must, unless the two-tiered language of Section One is meaningless-but these are gaps which most of us (aliens included) can probably live with. An alternative approach would be to understand the intent of the Fourteenth Amendment at a slightly higher level of generality. Nothing in the two-tiered language or legislative history requires that states be more free than the federal government to abridge privileges of the Bill. These privileges were understood in 1866 to be privileges enjoyed only by citizens because of Dred Scott. But if this aspect of Dred Scott were later abolished vis-à-vis the federal govemment for any privilege, perhaps we should read the Fourteenth Amendment, in the spirit of dynamic conformity, to incorporate the broader understanding of that privilege against states. As Ely rightly points out, the text can be read to include aliens; and the legislative history shows an intent to give aliens broader rights against states than they enjoyed against federal officials. Technical redundancy of the due process clause is also avoided because the clause would have independent bite until judges repudiated Dred Scott on the question of alien rights vis-à-vis the federal govemment. Under this approach, because of subsequent legal developments, the best reading of the original privileges or immunities clause may have evolved into something rather similar to what Ely implies it meant all along.

154. Duncan v. Louisiana, 391 U.S. 145, 166 (1968) (Black, J., concurring).

155. Berger, Incorporation, supra note 139, at 453; Morrison, supra note 139, at 159 . For a far more sophisticated version of this critique, see ELY, supra note 141, at 28.

156. Black's critics were quick to claim that even the "ostensibly ... "specific" rules laid down in the original Bill were "not very specific," Henkin, supra note 130, at 83-84, 86. As Professor Bobbitt has noted, however, incorporation did enable Black to substitute a longer set of words in the original Bill for the shorter set in the key sentence of Section One-no small thing to a textualist. PHILIP BOBBITT, CONSTTIUTIONAL FATE 32, 246-47 (1982). 
Amendment did not share Black's preoccupation with mechanical rules ${ }^{157}$ and wrote an amendment whose faithful interpretation and implementation, alas, cannot be mechanical. ${ }^{158}$ The best reading of the Amendment suggests that it "incorporates" the Bill of Rights in a far more subtle way than Black admitted, including both more and less than Amendments I-VIII.

Clearly, the privileges or immunities clause encompasses more than the federal Bill as such. Article I, Section 9, for example, declares that "The Privilege of the Writ of Habeas Corpus shall not be suspended," except in certain limited circumstances. Though Rawle had claimed otherwise in 1825, Barron squarely held that this clause, like all the other provisions in Section 9, bound only the federal government. ${ }^{159} \mathrm{By}$ withholding habeas from blacks claiming to be kidnapped, antebellum Southern states had facilitated the capture and return of alleged fugitive slaves. ${ }^{160}$ Though the Thirteenth Amendment had formally abolished slavery, states attempting to resurrect slavery de facto through Black Codes would predictably manipulate habeas to implement their scheme. Protecting the self-described "privilege" of habeas corpus against wayward states was thus of central concern to the framers of the Fourteenth Amendment. ${ }^{161}$ In their initial pronouncements on the Fourteenth Amendment in the Slaughter-House Cases, the Justices on the Supreme Court disagreed sharply about quite a lot, but none denied the Great Writ was indeed a "privilege of citizens of the United States" protected against state infringement by the new Amendment. Indeed, Justice Miller's majority opinion, generally thought today to have rendered the privileges or immunities clause utterly meaningless, explicitly listed "the privilege of habeas corpus" in its catalogue of Fourteenth Amendment rights. ${ }^{162}$

So far, Justice Black may not have been troubled, for like Amendments IVIII, the habeas clause is textually specified in the pre-1866 Constitution, and thus its incorporation too is relatively mechanical. ${ }^{163}$ Indeed, Black might

157. One partial explanation is that many congressional architects of Reconstruction envisioned not only judicial enforcement of Section One, but also - and perhaps more centrally-congressional enforcement. Section One was thus in part a grant of power to themselves, and they drafted it broadly.

158. For a similar analysis, see ELY, supra note 141, at 28 .

159. Various later contrarians sharply disagreed. See TENBROEK, supra note 64 , at $68,72-73,84$ (discussing centrality of universal habeas right in writings of Alvan Stewart, Lysander Spooner, Joel Tiffany, and James Birney).

160. Various Northem states responded with personal liberty laws designed to assure alleged fugitives access to the habeas writ. See HYMAN \& WIECEK, supra note 105, at 110, 152-53; see also id. at 107, 15052 (antebellum attacks on federal fugitive slave laws as violating habeas rights); CURTIS, supra note 106, at 43,106 (importance of habeas to abolitionists).

161. CONG. GlOBE, 39th Cong., 1st Sess. 475, 499, 1117, 1263, 2765 (1866) (invocations of habeas by Sens. Lyman Trumbull and Edgar Cowan, Reps. James Wilson and John Broomall, and Sen. Jacob Howard); CURTIS, supra note 106, at 144 (noting remarks of Rep. William Lawrence in 1866 election listing habeas as paradigmatic of 14th Amendment privileges or immunities).

162. 83 U.S. (16 Wall.) 36,79 (1873). This concession was, however, ambiguous, see infra text accompanying notes $281-85$.

163. See Adamson v. California, 332 U.S. 46, 91 (1947) (Black, J., dissenting) (contrasting "particular standards enumerated in the Bill of Rights and other parts of the Constitution" with "'natural law' ... undefined by the Constitution" (emphasis added)). 
have used Miller's concession to undermine the rest of Miller's argument, which seemed to resist, if not reject, total incorporation of the first eight amendments. Under what theory does the privileges or immunities clause incorporate the Great Writ specified in Article I, but not all the Great Rights specified after Article VIII? It would be silly to argue that the difference is that the habeas clause used the magic word "privilege" whereas later clauses in the Bill only used synonyms like "right" or "freedom." (Interestingly, Justice Bradley's dissent in Slaughter-House not only argued for incorporation of all the "personal privileges and immunities ... specified in the original Constitution, or in the early amendments of it"; it also included in the catalogue "the right of habeas corpus." 164 )

The habeas clause, however, presents hidden problems for Black as well, for its use of the word "privilege" calls attention to the word and naturally directs our gaze to the only other clause of the pre-1866 Constitution to use the word-the so-called comity clause of Article IV: "The Citizens of each State shall be entitled to all Privileges and Immunities of Citizens in the several States." These words clearly have some sort of connection to those of the Fourteenth Amendment-the pattern of the words "citizens," "privileges," and "immunities" in tight formation in both places calls for explanation. Black gave none. In the abstract, these words may not seem devastating to his mechanical view-especially in light of the widely held Republican view that these words in Article IV incorporated by reference the rights, freedoms, privileges, and immunities later specified in the federal Bill. ${ }^{165}$ But in 1866, those Article IV words also came packaged with an influential judicial gloss. And just as we cannot fully understand the words "No State shall" without reading Barron; or the words "citizens of the United States" without reckoning with Dred Scott; or the meaning of "due process" without confronting Murray's Lessee; so here, we must consider the leading comity clause case on the books in 1866: Justice Bushrod Washington's 1823 Circuit Court opinion in Corfield v. Coryell.

In Corfield, Washington identified "privileges and immunities" as those which

are, in their nature, fundamental; which belong, of right, to the citizens of all free governments; and which have, at all times, been enjoyed by the citizens of the several states which compose this Union . . [ [including] the following general heads: Protection by the government; the enjoyment of life and liberty, with the right to acquire and possess

164. 83 U.S. (16 Wall.) at 118 (Bradley, J., dissenting) (emphasis altered); see also id. at 115 ("Another of these rights was that of habeas corpus ....") (emphasis altered).

165. On the Republican connection between the comity clause and the federal Bill, see Crosskey, supra note 44 , passim; CURTIS, supra note 106 , at 43-44, 47-48, 62-91, 149-51; TENBROEK, supra note 64, at 96 n.3, 110 . 
property of every kind, and to pursue and obtain happiness and safety. ${ }^{106}$

Justice Washington went on to add to his nonexhaustive list "the benefit of the writ of habeas corpus" and the rights to "maintain actions of any kind in the courts" and to "take, hold and dispose of property, either real or personal."167 Though he did not cite Blackstone by name, Washington seemed to be following a quintessentially common law approach in deducing "fundamental" rights.

We have seen this kind of thinking before in the common law approach of Barron contrarians such as Rawle and Lumpkin: fundamental rights deriving from a variety of sources-typically, nature and history-preexisted their textual specification in legislative codes. Where We the People had given Our judicial imprimatur to a right by including it in the federal Bill, such a right was virtually by definition "fundamental." Indeed, Lumpkin described the Bill as "a legal decalogue for every civilized society, in all time to come," declaring "fundamental truths ... a the foundation of our free, republican institutions" and encompassing rights "at the bottom of every free government"168_formulations strikingly reminiscent of Corfield's ode to "fundamental" rights belonging to "the citizens of all free governments; and which have, at all times, been enjoyed by the citizens of America."

As we have seen, Lumpkin also suggested that for institutional reasons, rooted in fear of judicial discretion, perhaps judges should not invalidate statutes in the name of fundamental rights that had not yet received the People's imprimatur. But when read through the lens of the Article IV comity clause, as glossed by Corfield's ode, the language of Section One opens up broader possibilities. Corfield's nonexhaustive list of fundamental rights radiated well beyond those enumerated in the federal Bill; and this open-ended list received considerable attention in the Thirty-ninth Congress. Thus, Senator Lyman Trumbull and Representative James Wilson both quoted Washington's ode, Blackstone, and other broad common law and natural rights language in support of their 1866 Civil Rights Act, whose provisions were generally understood to be subsumed within the privileges or immunities clause of the subsequent Fourteenth Amendment. ${ }^{169}$ Corfield was again read broadly by Jacob Howard in his influential speech on Section One, which invoked both Washington's ode and the Bill of Rights as exemplifying "privileges and immunities of citizens of the United States."170 Justice Black, however, stressed the Bill and shunned the ode. ${ }^{171}$ For Black, Justice Washington's words conjured up the specter

166. 6 F. Cas. 546, 551-52 (C.C.E.D. Pa. 1823) (No. 3230).

167. $1 d$. at 552 .

168. Campbell v. State, 11 Ga. 353, 373 (1852); Nunn v. Georgia, $1 \mathrm{Ga} .243$, $250-51$ (1846).

169. CoNG. GLOBE, 39th Cong., 1st Sess. 474-75, 1117-19 (1866).

170. Id. at 2765-66.

171. Thus in his celebrated Adamson dissent, Black offered no account of or quotation to Corfield, editing out Howard's extended quotation of the case, and passing over in silence Bingham's later allusion 
of judges invalidating statutes by invoking nontextually specified fundamental rights and by giving common law rights, such as freedom of contract, constitutional status. The specter haunting Justice Black has a name. Its name is Lochner. ${ }^{172}$

Understanding that the privileges or immunities clause applied to various common law rights may not necessarily lead us to Lochner, however. For example, John Harrison has suggested that where a privilege or immunity derives not from the federal Constitution or Bill of Rights, but from common law or state law, the privileges or immunities clause prohibits only irrational discrimination in defining and enforcing these rights. ${ }^{173}$ Detailed analysis of his thoughtful and intricate arguments would take us rather far afield; for our purposes it is enough to note that Section One is not limited to privileges and immunities specified in the pre-1866 Constitution. Other common law rights were also included, though there remain questions about the precise kind of protection intended. For these nonconstitutional rights, perhaps only antidiscrimination ("equal") protection should be accorded, rather than fundamental rights ("full") protection. ${ }^{174}$ Questions also remain about judicial competence to find unspecified rights; ${ }^{175}$ but those fundamental rights that had already been specified and "declared" by We the People were easy cases for full judicial protection, and thus at the core of the Fourteenth Amendment.

So much then for Section One's penumbral radiations beyond Amendments I-VIII, for this is only half the story. Section One means not just more than

to "that decision in the fourth of Washington's Circuit Court Reports." Adamson v. California, 332 U.S. 46, 105, 115 (1947) (Black, J., dissenting).

172. Lochner v. New York, 198 U.S. 45 (1905). Lochner was cited with disapproval in Black's Adamson dissent. 332 U.S. at 83 n.12.

173. Harrison, supra note 145. For similar views, see 1 CURRIE, supra note 139, at 347-50; NELSON, supra note 64 , at $115-24$.

174. The language of the 1866 Civil Rights Act, widely seen as a precursor of Section One, speaks of the "full and equal benefit of all laws and proceedings for the security of person and property." Act of Apr. 9, 1866, ch, 31, $\$ 1,14$ Stat. 27 (emphasis added). For a reading of this Act as encompassing a fundamental rights core and an equal rights outer layer, see TENBROEK, supra note 64, at 189-90. See also Earl M. Maltz, Fourteenth Amendment Concepts in the Antebellum Era, 32 AM. J. LEGAL HIST. 305, 323 (1988) (similar analysis of two-tiered full and equal protection philosophy in antebellum jurisprudence). The language of the privileges or immunities clause can be understood as similarly two-tiered. Harrison's central textual argument is that the word "abridge" can be read to prohibit mere discrimination in the allocation of state-created rights-as in the Fourteenth Amendment Section Two's rules on "abridge[ment]" of the (state-law-created) "right to vote." Harrison, supra note 145 . Where only state-law-created rights are at stake, this is a plausible-perhaps the most plausible-reading of the word "abridge." But where rights specified and declared by We the People in Our Constitution are at stake, the best understanding of the word "abridge" in Section One surely comes from its fundamental rights counterpart in the First Amendment, whose language Section One so carefully tracks. See supra text accompanying notes 117-18; see also Livestock Dealers \& Butchers' Ass'n v. Crescent City Live-stock Landing \& Slaughter-House Co., 15 F. Cas. 649, 652-53 (C.C.D. La. 1870) (No. 8408) (Bradley, Circuit J.) (14th Amendment "not merely requires equality of privileges; but it demands that the privileges and immunities of all citizens shall be absolutely unabridged, unimpaired," and protects "privileges and immunities of an absolute and not merely of a relative character"). Plainly, the Amendment's framers meant to prevent a state from abridging speech critical of the Black Codes, even where the state "evenhandedly" abridged the rights of all speakers, white and black, Southern and Northern.

175. See supra text accompanying notes $91-94$. 
mechanical incorporation but also less. ${ }^{176}$ Once again, the habeas clause of Article I, Section 9 helps illustrate the point. Why does the Fourteenth Amendment incorporate this self-proclaimed privilege, but not, for example, its Section 9 companion clause, "No Capitation, or other direct, Tax shall be laid, unless in Proportion to the Census or Enumeration herein before directed to be taken"? The answer goes beyond the fact that the capitation clause does not talk like a privilege; it doesn't walk or act like a private right either. Rather, it sounds in federalism, guaranteeing a fair distribution of the federal tax burden among states. As a state right of sorts, the capitation clause resists easy incorporation against states.

Yet as I have argued elsewhere, the same holds true for various provisions of the original Bill of Rights. ${ }^{177}$ Justice Black himself saw the obvious difficulties of incorporating the Ninth and Tenth Amendments, which he read as pure federalism provisions. Thus, Black argued only for incorporation of the first eight amendments. But federalism insinuated itself throughout the original Bill of Rights: separating out citizen rights and state rights calls for a scalpel, not a meat cleaver. For example, is the establishment clause more like the habeas and free speech clauses (and thus an easy candidate for incorporation) or like the capitation clause and the Tenth Amendment (and thus rather awkward to incorporate)? Or is it, perhaps, some sort of sui generis hybrid that calls for "partial" incorporation? ? $^{178}$

Mechanical incorporation, then, rests on an optical illusion that the Constitution defines government structure, and the Bill declares citizen rights (redefining "the Bill" of course, as the first eight, or perhaps nine, amendments). The reality is, alas, more complicated. ${ }^{179}$ The original Constitution also declares rights (witness the habeas clause); the Bill also embodies structure (witness the Tenth Amendment); and both Constitution and Bill intertwine rights and structure.

The wording of the Fourteenth Amendment is remarkably sensitive to this more complicated reality. Section One requires us to ask whether a given provision of the Constitution or Bill really does declare a "privilege or immunity of citizens" rather than, for example, a right of states. The answer will often be anything but mechanical, requiring considerable judgment and hard choices. But this is exactly what the words of Section One demand. They avoid speaking of the "first eight amendments" or the "Bill of Rights" not just because these

176. It is at this point that my conclusions differ most from those of commentators who, in effect, adopt a "Bill of Rights plus" test for the Fourteenth Amendment, embracing both mechanical incorporation and fundamental fairness as independent principles of inclusion. See, e.g., Adamson v. California, 332 U.S. 46, 123-25 (1947) (Murphy \& Rutledge, JJ., dissenting); CuRTIS, supra note 106, at 125. Overall, my interpretive approach and conclusions are perhaps closest to those of John Hart Ely's. See ELY, supra note 141, at $22-30$.

177. See Amar, supra note $\dagger$.

178. For a preliminary analysis, see $i d$. at 1157-60.

179. See TENBROEK, supra note 64 , at 83 . 
words would have meant too little, but also because they would have meant too much. If "refined incorporation" of the sort I shall elaborate in Part III was indeed intended, it would have been hard to draft better language than the words of Section One.

\section{B. Glosses on the Text}

\section{The Thirty-ninth Congress}

\section{a. The Easy Case Made Easier}

The easy case for (nonmechanical) incorporation, then, rests on the plain meaning of the words of Section One circa 1866. Is there anything in the legislative history of these words that contradicts this straightforward reading? On the contrary.

Begin with Section One's principal draftsman, John Bingham. As we have seen, Bingham had argued before the House as early as 1859 that "whenever the Constitution guaranties to its citizens a right, either natural or conventional, such guarantee is in itself a limitation upon the States." ${ }^{\text {"180 }}$ Over the next few minutes, he made clear that such "guarantees" that "no State may rightfully ... impair" included the due process and just compensation mandates of "the fifth article of amendments," the "trial by jury," and "the right to know; to argue and to utter, according to conscience"-guarantees he described as "privileges and immunities of citizens of the United States." "181 "Citizens" here meant just that, as Bingham illustrated by quoting Dred Scott and other commentary. ${ }^{182}$ But Bingham also said that Dred Scott had gone too far, limiting certain rights, such as due process, that under both natural law and constitutional text extended to all persons, whether citizens or not. ${ }^{183}$ In a nutshell, Bingham's position was that no state could violate the Constitution's "wise and beneficent guaran-

180. Cong. Globe, 35th Cong., 2d Sess. 982 (1859).

181. Id. at $983-85$.

182. Id. at 983 .

183. Said Bingham:

[N]atural or inherent rights, which belong to all men irrespective of all conventional regulations, are by this constitution guarantied by the broad and comprehensive word "person," as contradistinguished from the limited term citizen-as in the fifth article of amendments ... that "no person shall be deprived of life, liberty, or property but by due process of law, nor shall private property be taken without just compensation."

Id. at 983; see also CONG. GLOBE, 37th Cong., 2d Sess. 1638 (1862) (remarks of John Bingham) (similar). Bingham's inclusion of the takings clause in this category explains a passing proposal he made seven years later in the Joint Reconstruction Committee, a proposal that Charles Fairman and Raoul Berger tried to use against Bingham and incorporation. See Fairman, supra note 113, at 41-42; RAOUL BERGER, GOVERNMENT BY JUDICIARY 142 (1977). For other criticism of Fairman and Berger on this point, see CURTIS, supra note 106 , at 83-84. 
tees of political rights to the citizens of the United States, as such, and of natural rights to all persons, whether citizens or strangers."184

Now these views, expressed in 1859 , track almost perfectly the natural meaning of the words Bingham drafted in 1866 as Section One of the Fourteenth Amendment. Thus, we find Bingham in 1866 repeating in speeches before the House arguments he had made seven years earlier. As we have already noted, Bingham once again quoted from Dred Scott on constitutional rights of "citizens" as "citizens," yet repeated his claim that Dred Scott was too stingy in refusing certain due process protections to "persons, whether citizens or strangers." 185 In another nutshell, no state should be allowed to violate "the privileges and immunities of all the citizens of the Republic and the inborn rights of every person within its jurisdiction." clause would protect citizen rights, and the due process and equal protection principles (which Bingham saw as linked, if not synonymous ${ }^{187}$ ) would protect the wider category of persons.

But what, precisely, were the "privileges or immunities of citizens of the United States"? In 1859, Bingham offered no comprehensive summary, but strongly implied that all rights and freedoms guaranteed by the Constitution were included. Though he did not use the magic words "Bill of Rights," he either quoted or paraphrased the rights to speech, press, religion, due process, just compensation, and jury trial. In 1866, Bingham spoke to the issue at much greater length and made himself about as clear as one could ever hope for. Over and over he described the privileges or immunities clause as encompassing "the bill of rights"-a phrase he used in a key speech on February 28th no less than a dozen times. ${ }^{188}$ In that speech, he also explained why a constitutional amendment was necessary, citing by name and quoting from the Supreme Court's opinions in Barron and one of its progeny, Livingston v. Moore. ${ }^{189}$ The day before, a colleague of Bingham's, Robert Hale, had suggested that states were already bound by the Bill, ${ }^{190}$ but Bingham set Hale and others straight with the following quotation from Livingston: "As to the amendments of the Constitution of the United States, they must be put out of the case, since it is now settled that those amendments do not extend to the States . . .."191 Six weeks later Bingham again held forth on the need for his amendment, invoking "the bill of rights" six times in a single speech and again reminding his colleagues that it "has been solemnly ruled by the Supreme Court of the

184. CONG. GLOBE, 35th Cong., 2d Sess. 983 (1859).

185. Quoted supra text accompanying notes $135,142$.

186. CONG. GLOBE, 39th Cong., 1st Sess. 2542 (1866).

187. See CONG. GLOBE, 37th Cong., 2d Sess. 1638 (1862) (remarks of John Bingham); Crosskey, supra note 44 , at $16,25,69$; Graham, supra note 98 , at $396-97$ \& n.87.

188. CONG. GloBE, 39th Cong., 1st Sess. 1088-94 (1866).

189. Id. at $1089-90$.

190. Id. at 1064 .

191. Id. at 1090 (quoting Livingston v. Moore, 32 U.S. (7 Pet.) 469, 551-52 (1833)). 
United States," that "the bill of rights ... does not limit the powers of States." ${ }^{, 192}$ In 1871, several years after the Fourteenth Amendment's ratification, Bingham was once more called upon to parse its words. He yet again cited by name and quoted from Barron, ${ }^{193}$ and here too he immediately linked "the privileges and immunities of citizens of the United States" with the Bill of Rights:

[T]he privileges and immunities of citizens of the United States, as contradistinguished from citizens of a State, are chiefly defined in the first eight amendments to the Constitution of the United States. Those eight amendments are as follows. [Bingham then proceeded to read the first eight amendments word for word.] These eight articles I have shown never were limitations upon the power of the States, until made so by the fourteenth amendment. ${ }^{194}$

In light of all this, it is frankly astonishing that some scholars, most notably Charles Fairman and Raoul Berger, have suggested that when Bingham invoked "the bill of rights," he didn't mean what he said. ${ }^{195}$

Two years before Bingham introduced his amendment, Representative James Wilson had made clear that he too understood the "privileges and immunities of citizens of the United States" to include the guarantees of the

192. Id. at 1291-93.

193. Quoted supra text accompanying note 116.

194. CONG. GLOBE, 42 d Cong., 1st Sess. 84 app. (1871).

195. Fairman, supra note 113 , at $26,33-34,134$, 136; BERGER, supra note 183, at 141-42; Berger, Incorporation, supra note 139, at 463 . If the issue is whether references to the "bill of rights" in 1866 naturally called to mind the first nine or ten rather than eight amendments-a point to which we shall return later-the observation about the ambiguity of the phrase is fair enough. But Fairman and Berger meant something quite different: that when Bingham said the "bill of rights" in 1866, perhaps he did not even mean the first eight amendments. Yet as we have seen, Bingham painstakingly cited Barron, quoted the language from Livingston on "the amendments to the Constitution of the United States," and later paraphrased these cases as holdings on "the bill of rights." Indeed, in the very same breath in which he first invoked Barron, Bingham spoke of "the bill of rights under the articles of amendment." CONG. GLOBE, 39th Cong., 1st Sess. 1089 (1866) (emphasis added). Over the course of 1866, Bingham had occasion to refer specifically to "freedom of speech," the right to "teach" religion, "freedom of conscience," "due process," the right to "just compensation" and protection against "confiscation," and the right against "cruel and unusual punishments." Id. at 158, 1065, 1094, 2542; KENDRICK, supra note 146, at 85; Fairman, supra note 113, at 76 (quoting CrNCINNATI COM., Aug. 27, 1866, at 1). If all that weren't enough to make clear Bingham was using the words "the bill of rights" in their ordinary sense, his speeches both before and after 1866 offer powerful confirmation. For example, his 1871 speech declared: "Jefferson well said of the first eight articles of amendments to the Constitution of the United States, they constitute the American Bill of Rights." CONG. GLOBE, 42d Cong., 1st Sess. 84 app. (1871); see also CONG. GLOBE, 37th Cong., 2d Sess. 1638 (1862) (remarks of John Bingham) (discussing due process and just compensation clauses of "the bill of rights"). More important, of course, everyone else in the 39th Congress understood Bingham's references to "the bill of rights" as meaning just that. On February 27th, the day after Bingham first introduced his amendment in the House as a proposal to enforce "this immortal bill of rights," CONG. GLOBE, 39th Cong., 1st Sess. 1034 (1866), Robert Hale responded with his own ode to "the bill of rights," which he unambiguously defined in passing as "these amendments to the Constitution, numbered from one to ten." Id. at 1064. Immediately following yet another Bingham paean to "the bill of rights," $i d$. at 1291-93, James Wilson invoked the due process clause of the Fifth Amendment, which "I find in the bill of rights which [Mr. Bingham] desires to have enforced by an amendment." Id. at 1294. 
amendments. His words also show that he deemed all rights and freedoms in the Bill-even those declared only against "Congress"- to be binding on state governments:

Freedom of religious opinion, freedom of speech and press, and the right of assemblage for the purpose of petition belong to every American citizen .... With these rights no State may interfere ....

Sir, I might enumerate many other constitutional rights of the citizen which slavery has disregarded and practically destroyed, but I have [said] enough to illustrate my proposition: that slavery . . . denies to the citizens of each State the privileges and immunities of citizens ....

... The people of the free States should insist on ample protection to their rights, privileges and immunities, which are none other than those which the Constitution was designed to secure to all citizens alike.... . ${ }^{196}$

Plainly, then, Wilson and Bingham both read that Bill through contrarian lenses, though Bingham was far more conscious that the Supreme Court had rejected this reading. And both leaders understood that the plain meaning of Section One was that henceforth, the federal government would have explicit power to compel state compliance with all the "privileges" and "immunities" of "citizens" set out in the Bill. Shortly before the Amendment came before the House for final approval, political leader Thaddeus Stevens delivered a speech describing its provisions. Here are his opening words on Section One:

I can hardly believe that any person can be found who will not admit that every one of these provisions is just. They are all asserted, in some form or other, in our DECLARATION or [of?] organic law. But the Constitution limits only the action of Congress, and is not a limitation on the States. This amendment supplies that defect .... ${ }^{197}$

In the Senate, Jacob Howard offered the most comprehensive analysis of Section One:

196. CONG. GLOBE, 38th Cong., 1st Sess. 1202-03 (1864).

Hale echoed these sentiments on February 27, 1866:

[T] rights, a bill of rights for the protection of the citizen, and defining and limiting the power of Federal and State legislation.

... [T]here has been from first to last, a violation of the provisions in this bill of rights by the very existence of slavery itself. CONG. GloBE, 39th Cong., 1st Sess. 1064-65 (1866).

197. Id. at 2459. If, as my bracketed question suggests, Stevens' statement was inaccurately transcribed and he in fact said "of" not "or," the word DECLARATION refers not to Jefferson's document of July 4, 1776, but instead to a declaratory theory of the Constitution and Bill of Rights-whose wording does indeed track that of Section One far more than does the wording of Jefferson's Declaration of Independence. 
[I]ts first clause, [which] I regard as very important . . . relates to the privileges and immunities of citizens of the United States as such, and as distinguished from all other persons ..... [Here is what a] very learned and excellent judge says about these privileges and immunities of the citizens of each State in the several States [in] the case of Corfield vs. Coryell. [Howard then quoted Corfield at length.]

Such is the character of the privileges and immunities spoken of in [Article IV]. To these privileges and immunities, whatever they may be-for they are not and cannot be fully defined in their entire extent and precise nature-to these should be added the personal rights guarantied and secured by the first eight amendments of the Constitution; such as the freedom of speech and of the press; the right of the people peaceably to assemble and petition the Government for a redress of grievances, a right appertaining to each and all of the people; the right to keep and bear arms; the right to be exempted from the quartering of soldiers in a house without the consent of the owner; the right to be exempt from unreasonable searches and seizures, and from any search or seizure except by virtue of a warrant issued upon a formal oath or affidavit; the right of an accused person to be informed of the nature of the accusation against him, and his right to be tried by an impartial jury of the vicinage; and also the right to be secure against excessive bail and against cruel and unusual punishments.

... [T] doctrine is, that all these immunities, privileges, rights, thus guarantied by the Constitution or recognized by it ... do not operate in the slightest degree as a restraint or prohibition upon State legislation . . . . [1] $\mathrm{t}$ has been repeatedly held that the restriction contained in the Constitution against the taking of private property for public use without just compensation is not a restriction upon State legislation, but applies only to the legislation of Congress.

... [T] hese guarantees ... stand simply as a bill of rights in the Constitution ... [and] States are not restrained from violating the principles embraced in them .... The great object of the first section of this amendment is, therefore, to restrain the power of the States and compel them at all times to respect these great fundamental guarantees. ${ }^{198}$

There is much more legislative history to confirm the material we have canvassed so far-the leading scholarly work counts no fewer than thirty Republican statements in the Thirty-eighth and Thirty-ninth Congresses voicing contrarian sentiments, and not one supporting Barron. ${ }^{199}$ As a lover of mercy, however, I shall resist the temptation to present all the evidence that antiincorporationists have overlooked or distorted. For what we have seen thus far virtually clinches the case for some sort of incorporation.

Consider first the sources. John Bingham was the author of Section One. Thaddeus Stevens was not only the political leader of the House, but also head

198. Id. at $2765-66$.

199. CURTIS, supra note 106, at 112. 
of the House delegation of the all-important Committee on Reconstruction that officially reported the Fourteenth Amendment. Jacob Howard was Stevens' acting Joint Committee counterpart in the Senate. James Wilson was Chair of the House Judiciary Committee and sponsor of the Civil Rights Act of 1866, whose provisions Section One was consciously designed and widely understood to embrace.

Consider next the context. Bingham's audience knew he was the author and thus paid particular attention to his expositions. ${ }^{200}$ Stevens delivered a written speech (a rarity for him, as the New York Herald noted the next day) ${ }^{201}$ in his formal capacity as House Chairman of the Joint Committee. Howard too purported to speak on behalf of the committee, addressing a packed gallery in a speech whose passage on the Bill of Rights was reprinted in full in both the New York Times and the Herald. ${ }^{202}$ (The popular press had also covered Bingham's earlier statements. ${ }^{203}$ ) And not a single person in either house spoke up to deny these men's interpretation of Section One. Surely, if the words of Section One meant something different, here was the time to stand up and say so.

Consider, finally, that all these men offered glosses that mesh perfectly with each other and-most importantly - with the plain meaning of the words of Section One.

\section{b. Incorporating Anti-Incorporation Insights}

If the key sentence of Section One does not in some way or another incorporate the Bill of Rights, then just what does it do? The two most prominent critics of incorporation, Charles Fairman and Raoul Berger, have suggested two radically different alternatives. Each has something going for it-something that does tend to undermine Black's brand of mechanical incorporation-but something that in fact supports a refined model of incorporation.

\section{(i) Fairman}

Professor Charles Fairman spent so much energy attacking Justice Black that he failed to offer any sustained narrative in support of an alternative reading of the Fourteenth Amendment. After about 130 pages of Black-bashing,

200. Even Senators knew of Bingham's authorship and views. Senator James Doolittle, for example, reminded his colleagues that Section One had been prepared by "Mr. Bingham" who, Doolittle twitted, had also argued that the Civil Rights Act was unconstitutional under extant case law and required a constitutional amendment (namely Bingham's) to validate it. Doolittle went on to praise Bingham's "very able speech" in the House which argued that only an amendment would suffice to "declare the civil rights of all persons" (Doolittle's paraphrase)-a speech in which Bingham invoked "the bill of rights" a half dozen times. CoNG. GloBE, 39th Cong., 1st Sess. 2896 (1866).

201. See JOSEPH B. JAMES, THE FRAMING of the FouRTEENTH AMENDMENT 125 (1956).

202. Id. at 135-36; Fairman, supra note 113, at 68-69; Crosskey, supra note 44, at 102-03.

203. CURTIS, supra note 106 , at 128 . 
Fairman concluded that "pretty clearly there never was any such clear conception" of precisely what would be included in and excluded from Section One's commands. ${ }^{204}$ Nevertheless, Fairman cast his lot with Frankfurter, suggesting that principles of fundamental faimess and ordered liberty were probably better touchstones than anything else. And "surely," Fairman emphasized, "the federal requirements as to juries were not included."205

Fairman was half right. Nothing in the words or history of Section One yields a precise principle of exclusion. Had its framers intended to limit its scope to only privileges, rights, and freedoms declared in the pre- 1866 Constitution, better words could have been found. But nothing in Fairman's account of the legislative history of the Thirty-ninth Congress shows that jury trial rights, or any other provisions of the federal Bill, were not seen as fundamental. Howard, for example, plainly said that all the privileges and immunities of Amendments I-VIII were included, but he also simultaneously described them as "these great fundamental guarantees." 206 Wilson's words in the Thirty-ninth Congress were almost identical, referring to "the great fundamental rights embraced in the bill of rights," which he had moments earlier described as "the great fundamental rights belonging to the citizen."207 Wilson's Senate cosponsor of the Civil Rights Act was Lyman Trumbull, and he, too, equated constitutional rights with fundamental rights: "Each State, so [long as] it does not abridge the great fundamental rights belonging, under the Constitution, to all citizens, may grant or withhold such civil rights as it pleases."208

Thus, we find repeated claims that all privileges and immunities guaranteed in the Bill are indeed fundamental and worthy of Fourteenth Amendment protection. In light of these emphatic claims, did anyone argue that jury provisions - or any other rights-in the Bill were not fundamental, and should not be imposed on states? Fairman presents no one. He instead tries to make hay out of speeches talking fundamental rights talk without explicitly mentioning "the Bill of Rights." Typical of this dubious strategy is his treatment of Senator John B. Henderson who, several days after Howard's speech, said "it will be a loss of time to discuss the remaining provisions of the section, for they merely secure the rights that attach to citizenship in all free Governments." ${ }^{209}$ Fairman commented: "Unless the first eight Amendments enumerate 'rights that attach to citizenship in all free governments,' Henderson's understanding is to

204. Fairman, supra note 113, at 138. I use the word "bashing" advisedly. Though his work has drawn much praise, in my view Professor Fairman was a rather un-Fair-man in assessing the evidence for incorporation.

205. Id. at 139.

206. Quoted supra text accompanying note 198.

207. CONG. GLOBE, 39th Cong., 1st Sess. 1294 (1866); see also id. at 1118 (remarks of Wilson) (referring to "the great fundamental civil rights" of "citizens of the United States, as such" protected by "the American Constitution").

208. Id. at 1760; see also id. at 1151-53 (remarks of Rep. Russell Thayer) (equating constitutional rights of the citizen with "fundamental" rights).

209. Id. at 3031 . 
be counted as opposed to that of Howard."210 But Fairman's "unless" swallows up the rest. Howard not only said plainly and at length that the rights in Amendments I-VIII were encompassed by Section One (which Henderson nowhere denied); and Howard not only simultaneously defined these rights as "fundamental" (again, not a peep from Henderson); but moments later Howard appeared to equate, rather than distinguish between, "the privileges and immunities ... secured by the first eight amendments of the Constitution" and "those fundamental rights lying at the basis of all society and without which a people cannot exist except as slaves."211 Henderson's passing comment seems more an echo than a refutation of Howard's elaborate remarks.

We have seen thetoric like Howard's before. In his oral argument in Holmes v. Jennison, Van Ness had described the rights in the Bill as "principles which lie at the very foundation of civil liberty"; and in two cases decided years apart, Lumpkin had variously described the Bill—explicitly including jury trial provisions-as declaring "fundamental truths ... at the foundation of our free, republican institutions," and rights "at the bottom of every free government. ${ }^{, 212}$ As we have already noted, the idea that rights declared in the Bill were ipso facto fundamental had deep jurisprudential roots in the methodology of the common law and in the fear of unfettered judicial discretion.

The Civil War experience provided powerful ideological, almost religious, reinforcement. The war had of course taken a terrible toll in lives and limbs, and even victory tasted bittersweet. Republicans in 1866 needed to convince their constituents that all had not been in vain, that the noble goals of the Union-preservation of nation and (later) freedom-had been worth the fight and had been won. The Bill was a perfect symbol of both goals, even better in some ways than the Declaration of Independence and the original Constitution. The Declaration had arguably preceded nationhood and featured language of "free and independent states," a phrase repeatedly invoked on behalf of secession. ${ }^{213}$ The original Constitution had been tainted by its open compromises with slavery, and it, too, could be seen as the product of independent state conventions, none of whom could bind any other (again, points repeatedly emphasized by secessionists). ${ }^{214}$ The Bill, by contrast, clearly derived from America as a nation, and proclaimed freedom, not slavery. What better embodiment of the slogan, "Freedom National"-especially once the Bill's states' rights features were filtered out by the phrase "privileges or immunities of citizens of the United States"?

210. Fairman, supra note 113, at 63 .

211. CONG. GLOBE, 39th Cong., 1st Sess. 2765-66 (1866).

212. Quoted supra text accompanying notes 80, 168.

213. THE DECLARATION OF INDEPENDENCE para. 32 (U.S. 1776); 1 JeFFERSON DAVIS, THE RISE AND FALL OF THE CONFEDERATE GOVERNMENT 86 (1958) (T. Yoseloff 1881) (authored by President of so-called Confederate States of America.)

214. See 1 DAVIS, supra note 213, at 99-120. But see Amar, supra note 21, at 1444-66 (rejecting secessionist interpretation of Founding). 
It has become commonplace to remark upon Lincoln's blending of religious and constitutional rhetoric-in his Inaugural and Gettysburg Addresses, for example-but Bingham's imagery also bears notice. For him the Bill was not simply "immortal,"215 as he preached in his maiden sermon in support of his Amendment, but "sacred," a word that punctuates his most extended meditation on the Bill:

As a further security for the enforcement of the Constitution, and especially of this sacred bill of rights, to all the citizens and all the people of the United States, it is further provided that the members of the several State Legislatures and all executive and judicial officers, both of the United States and of the several States, shall be bound by oath or affirmation to support this Constitution. The oath, the most solemn compact which man can make with his Maker, was to bind the State Legislatures, executive officers, and judges to sacredly respect the Constitution and all the rights secured by it. . . . [The Bill of Rights encompasses] all the sacred rights of person-those rights dear to freemen and formidable only to tyrants - and of which the fathers of the Republic spoke, after God had given them the victory .... ${ }^{216}$

Bingham waxed on at length proclaiming the need for "fidelity to the sacred cause of the Constitution," describing the Founders' Bill as "essential provisions of your Constitution, divine in their justice, sublime in their humanity," invoking "God" countless times, and in fact closing with a reference to "the imperishable attribute of the God of nations."217 Given all this iconography, the suggestion that some provisions of the Founders' Decalogue were dispensable would be as jarring (heretical is the le mot juste) as the claim that some of the Ten Commandments really were not, well, fundamental.

Fairman was remarkably insensitive to all of this and indeed, quite anachronistic. Because he, in 1949, deemed various parts of the Bill to be optional or outdated, he tended to attribute similar views to the 1866 Congress: When Bingham said "bill of rights" he couldn't have meant it; his rhetoric showed sloppy thinking rather than a worldview to be taken seriously; silence on the other side must have meant that Bingham and company had not been understood; for surely some sane lawyer would otherwise have clearly spoken out against such silliness; and so on. Hugo Black, not Charles Fairman, proved the more faithful historian, for he understood-because he shared-the almost mystical attachment to the Bill of Rights exemplified by John Bingham. The title of Black's Carpentier Lectures on incorporation (among other things) says it all, and quite self-consciously: "A Constitutional Faith."218

215. CONG. GLOBE, 39th Cong., 1st Sess. 1034 (1866).

216. Id. at 1090 .

217. Id. at 1090-94; $c f$. id. at 1034 (remarks of Bingham on "immortal" bill of rights).

218. BLACK, supra note 4. 
Bingham's constitutional faith was not simply a private affair, for he wove it into the very fabric of the key sentence of Section One. How else to account for the sentence's pious blending of phraseology from no less than four sections of the pre-1866 Constitution (Article I, Section 10; Article IV; and Amendments I and V) and its paraphrase of a fifth (substituting "citizens" for the Preamble's "We the People")?

Of course, not all of Bingham's colleagues shared his faith, but they too had obvious reasons to value virtually every privilege and immunity in the Bill. Even if not sacred because given from above (from The Fathers, The People, or The Almighty) the Bill had proved its secular value-if only by its unavailability -in the trenches of the antebellum crusade against slavery. As we have seen, slavery led to state repudiation of virtually every one of the Bill's rights and freedoms, most definitely including the Bill's "inestimable privilege" of juries-grand, petit, and civil-in cases involving liberty. ${ }^{219}$ As it had for Anti-Federalists in the 1780's, the Bill encompassed for Republicans in the 1860 's an armory of indispensable weapons against a tyranny that people had seen with their own eyes. The difference, of course, was that unlike the tyranny of George III, the tyranny of slavery could not be blamed on a distant and dictatorial center, but instead had been perpetrated by local democracies. Just as the price of peace and union in 1789 was a Bill of Rights against the center, so the price of peace and (re)union in 1866 was a Bill of Rights against the periphery.

The Bill thus stood as a handy pledge of the good faith of the South, enforceable by congressional refusal to readmit states that continued to violate its provisions. On the very day Bingham preached his most extended sermon on the Bill in the House, Senator James Nye proclaimed that Congress had "no power to invade" privileges of the Bill such as "freedom of speech," "freedom of the press," "freedom in the exercise of religion," and the "security of person," but that Congress did have power to "restrain the respective States from infracting them" by continuing to exclude as unrepublican any state violating these "personal rights." 220 Representative Roswell Hart agreed several weeks later, defining a "republican" government as one where:

"citizens shall be entitled to all privileges and immunities of other citizens;" where "no law shall be made prohibiting the free exercise of religion;" where "the right of the people to keep and bear arms shall not be infringed;" where "the right of the people to be secure in their persons, houses, papers and effects, against unreasonable searches and seizures, shall not be violated," and where "no person shall be deprived of life, liberty, or property without due process of law."221

219. Though technically civil, suits involving alleged fugitive slaves implicated bodily liberty more dramatically than most criminal cases.

220. CONG. GLOBE, 39th Cong., 1st Sess. 1072 (1866).

221. Id. at 1629 . 
In a similar vein, Congressman Samuel Moulton argued against readmittance of various Southern states because "there is neither freedom of speech, of the press, or protection to life, liberty, or property," and Representative Sidney Clarke opposed restoration of Mississippi to Congress because its constitutional provision disarming blacks violated the Second Amendment command that "the right of the people to keep and bear arms shall not be infringed."222

In all of these roles-as a declaratory landmark for judges trying to find higher law, as a postwar symbol of "Freedom National," as a sacred gift from above, as a time-tested arsenal against tyranny, as a readymade pledge of states' good faith, as a justiciable definition of tepublican government, and as a prudent bar against hasty readmission of the South-the Bill as a whole was more than the sum of its parts. Thus, Fairman failed to find Republicans in the Thirty-ninth Congress picking the Bill apart, saying this right is fundamental but that right is not.

Despite its flaws, Fairman's analysis does yield two important insights that any sensitive theory of incorporation must accommodate. First, Fairman rightly saw that the Bill of Rights was invoked in 1866 at a rather high level of generality. Virtually no one in Congress or in the states carefully considered clause by clause exactly how the Bill could be sensibly incorporated. Second, Fairman understood the Bill of 1789 as a creature of its time, and intuited that some of its features might not fit well with the basic purposes of the Fourteenth Amendment, had these features been carefully considered in 1866. Fairman's precise formulation of this intuition-that "surely the federal requirements as to juries were not" part of Section One ${ }^{223}$-is dubious; but we shall see that various aspects of the original Bill, including its jury centerpieces, do not mechanically incorporate jot for jot. Perhaps we should recast Fairman's formulation as follows: "surely the federal[ism-based] requirements" in the original Bill should not be unthinkingly imposed on states.

\section{(ii) Berger}

Whereas Fairman argued for a more open-ended alternative to mechanical incorporation, Raoul Berger followed Hugo Black by suggesting that Section One had a precisely determinate meaning. But while Black read Section One as a term of art meaning "No State shall abridge the Bill of Rights," Berger read the section as a very different term of art. Berger's argument proceeded in two steps. First, he insisted that Section One's commands were identical in meaning to those of the Civil Rights Act of $1866 .{ }^{224}$ Second, he read that Act

222. Id. at $1617,1838-39$.

223. Fairman, supra note 113 , at 139.

224. BERGER, FOURTEENTH AMENDMENT, supra note 139, at 22; cf. Fairman, supra note 113, at 44 (suggesting "correspondence" and "essential[] identi[ty]" between Act and Section One). 
narrowly, denying that the Act itself in any way incorporated the Bill of Rights. ${ }^{225}$ Although each step in isolation is problematic enough, the biggest question is how Berger can conjoin them, for each step in fact undoes the other.

The Civil Rights Act presents a great many interpretive riddles of its own, which would take us far afield; but it is enough to note here that its intricate phrasings have almost no textual overlap with the wording of the key sentence of Section One. ${ }^{226}$ If the two were supposed to be not merely complementary but identical, why did the same Congress use radically different words? At the very least, why did Section One not explicitly refer to the Act? Does Berger believe that the key sentence applied in the territories, as the Civil Rights Act plainly did?

Of course, Section One did not explicitly refer to "the Bill of Rights" either, but as we saw earlier, any such simplistic reference would have been both over and underinclusive. Berger, by contrast, claims that the Act and Section One were identical, despite the lack of textual overlap or cross-reference. Berger places great weight on various statements made in Congress, but only the text of the Fourteenth Amendment was presented to the American people for their ratification. And nothing in the text of the key sentence would lead an average reader to understand it to mean no more and no less than the rather obscure and highly intricate words of a recent congressional statute, however important the statute might be. By contrast, ordinary Americans familiar since childhood with the Bill of Rights were likely to understand its "rights" and "freedoms" as paradigmatic, even if not exhaustive, of their "privileges" and "immunities" as "citizens of the United States." (Recall that the Bill was in fact worded so that, like scripture, it might be easily memorized and internalized by ordinary Americans. ${ }^{227}$ ) What's more, Section One's selfconscious blending of phrases from the pre-1866 Constitution would cue a careful reader to look to the Constitution first for (nonexhaustive) definitions of the rights and privileges of Americans.

In any event, the legislative history fails to establish the precise identity Berger claims, but rather illustrates only that the broad language of Section One was consciously designed and widely understood to encompass - that is, to be at least as broad as-the commands of the Civil Rights Act. But as its language

225. BERGER, FOURTEENTH AMENDMENT, supra note 139, at 115-19.

226. In relevant part, the Act provided:

[C]itizens of the United States . . . of every race and color, without regard to any previous condition of slavery or involuntary servitude, except as a punishment for crime whereof the party shall have been duly convicted, shall have the same right, in every State and Territory in the United States, to make and enforce contracts, to sue, be parties, and give evidence, to inherit, purchase, lease, sell, hold, and convey real and personal property, and to full and equal benefit of all laws and proceedings for the security of person and property, as is enjoyed by white citizens, and shall be subject to like punishment, pains, and penalties, and to none other, any law, statute, ordinance, regulation, or custom, to the contrary notwithstanding.

Act of Apr. 9, 1866, ch. 31, \$1, 14 Stat. 27 (1866).

227. See Amar, supra note $\dagger$, at 1208-09; cf. supra note 80 and accompanying text. 
and its proponents made clear, and no one denied, Section One was also consciously designed to encompass the guarantees of the Bill of Rights. This is actually less confusing than it might sound; for the best reading of the Civil Rights Act suggests that it, too, was understood to incorporate the citizen rights and freedoms of the Bill of Rights. Berger tries to argue that the Act prohibited only racial discrimination, but if so, the first step of his argument collapses. For if Section One and the Act were indeed identical in their substantive scope, as he insists, then the Act must go beyond nondiscrimination to require states to provide all persons with due process. The Act does contain language that can be read to incorporate due process requirements; but as Michael Kent Curtis has shown, that very same language must also then be read to incorporate all the other rights and privileges of the Bill of Rights. ${ }^{228}$

Berger's argument thus self-destructs. To save his first step, we must read the Act to go beyond nondiscrimination (for due process has bite against even nondiscriminatory laws); but in so doing, we undermine Berger's second step, which tries to neuter the incorporationist language of the Act. To put the point another way, the more we insist on the linkage between the Act and Section One, the more relevant the language and legislative history of the Amendment become in clarifying the intricate wording of the Act. And as we have seen,

228. CuRTIS, supra note 106, at 71-83. Though inartfully drafted, the Act's last clause speaks of the "full ... benefit of all laws and proceedings for the security of person and property." The rights and freedoms of the federal Bill had long been understood as precisely fitting this description. For example, Blackstone catalogued various common law antecedents of the Bill of Rights as encompassing "the right of personal security, the right of personal liberty, and the right of private property;" and Lumpkin in Campbell had described the federal Bill as providing "security for personal liberty and private property." 1 BLACKSTONE, supra note 126, at*127-45; Campbell v. State, 11 Ga. 353, 372 (1853); see also JOEL. TIFFANY, A TREATISE ON THE UNCONSTITUTIONALITY OF AMERICAN SLAVERY 97 (Cleveland, J. Calyer 1849) (leading antebellum antislavery tract describing Bill of Rights as "guarantys . . for personal security, personal liberty and private property"); CONG. GLOBE, 39 th Cong., Ist Sess. 1833 (1366) (remarks of Rep. William Lawrence) (linking language of civil rights bill with due process clause of "the bill of rights to the national Constitution"). In the Thirty-ninth Congress, Senator Lyman Trumbull introduced the Civil Rights Act by saying it would protect the rights to teach, preach, and possess firearms-rights of course declared in the first two federal amendments. Id. at 474-75; see also id. at 478, 1266 (remarks of Sen. Willard Saulsbury and Rep. Henry Raymond) (noting that Act encompassed right to bear arms). Trumbull's House counterpart, James Wilson, spoke even more expansively, declaring that the Act would protect "the great fundamental rights embraced in the bill of rights." Id. at 1294. The most dramatic evidence, however, comes from the Civil Rights Act's Siamese twin, the Freedman's Bureau Act. Initially introduced as a single act, the two bills were later split, but were understood as in pari materia. As finally adopted, the Freedman's Bureau Act spoke of the "full ... benefit of all laws and proceedings concerning personal liberty, personal security, and [property,] including the constitutional right to bear arms." 14 Stat. 173, 176 (1866) (emphasis added). This last clause was understood as declaratory, simply clarifying what was already implicit. FLACK, supra note 146, at 17. All of this thus suggests that the Second Amendment right to bear arms-and presumably all other rights and freedoms in the Bill of Rights-were encompassed by both the Freedman's Bureau Act and its companion Civil Rights Act. (Of course, adoption of both Acts presupposed congressional power to impose the general requirements of the Bill of Rights on states. Bingham, relying on Barron, denied that Congress had such power, and therefore argued that a constitutional amendment was required to validate the Civil Rights Act. CoNG. GloBE, 39th Cong., 1st Sess. 1291-93 (1866).) 
the Amendment's language and legislative history do indeed cross-reference the rights and freedoms of the Bill of Rights. ${ }^{229}$

Berger's emphasis on the Civil Rights Act is nevertheless instructive. Much of the language and legislative history of the Act stressed the importance of fundamental, Blackstonian common law rights. As we shall see, Blackstone and the common law tradition may help us separate out those aspects of the pre1866 Constitution that are indeed privileges or immunities of citizens from other aspects that may not sensibly incorporate.

\section{Ratification: The Sounds of Silence}

The Thirty-ninth Congress, of course, had only the power to propose. Yet both the text of Section One and the public gloss Congress placed on that text made clear that what Congress was proposing was rothing less than a transformation of the original Bill of Rights. Fairman argues that virtually no one during the ratification debates explicitly reaffirmed incorporation, but Michael Kent Curtis has shown that here, too, Fairman overlooks a great deal of affirmative evidence for incorporation. ${ }^{230}$ Moreover, the evidence we have canvassed thus far warrants shifting the burden, at least of production, onto those who would claim that Section One somehow changed its meaning during the ratification process. Yet Fairman presents not a single soul who explicitly denied that the text meant what it said: that no state shall abridge the rights and freedoms of Americans, most obviously those declared in the Bill of Rights.

\section{a. Ratification Silence and the Incorporation Debate}

Fairman argues that if we listen carefully, we can hear a roaring silence that overwhelms incorporation. Rather than stuffing words into Fairman's mouth, I shall let him speak for himself, with my italics added:

If it was understood, in the legislatures that considered the proposed Amendment, that its adoption would impose upon the state governments the provisions of the federal Bill of Rights, then almost certainly each legislature would take note of what the effect would be upon the constitutional law and practice of its own state. If, for instance, the state permitted one charged with "a capital or otherwise infamous crime" to be tried upon information rather than "on a presentment or indictment of a Grand Jury" (Amend. V) . . presumably its legislature

229. Berger's misstatements, distortions, and nonsequiturs are legion, but two especially egregious claims merit special response: (1) "No reference to the Bill of Rights is to be found in the history of the Civil Rights Bill . . . ." (2) 'The [Civil Rights] Bill made no provision for a right to 'assemble or bear arms' nor did any spokesman for it read these terms into the bill." BERGER, FOURTEENTH AMENDMENT, supra note 139 , at $24 \mathrm{n} .21,73$. The speeches quoted or cited in the preceding footnote alone suffice to establish the gross error of such claims.

230. Compare Fairman, supra note 113, at 81-132 with CURTIS, supra note 106, at 131-53. 
would not knowingly ratify such an Amendment without giving some thought to the implications. ... [W] [Were the imposition of Amendments I to VIII would put a stop to some established practice, such as the mode of trial in civil or criminal cases, then surely -if the Amendment was really supposed to incorporate the Bill of Rights-one would expect to find a marked reaction. ... Conversely, if we found disparity coupled with complete inaction, it would be very hard to believe the Fourteenth Amendment was understood to have that effect. ${ }^{231}$

As I hope my italics indicate, Fairman builds his argument on the assumption that the implications of Section One's key sentence were carefully considered during the ratification period. To twentieth-century readers, this seems an obviously sensible assumption. Isn't the key sentence the centerpiece of the Fourteenth Amendment? Yet as Fairman's own evidence shows, his assumption is false. His argument, built on silence, is an argument built on sand.

Fairman's most dramatic evidence concerns the grand jury. In nine or ten states, state constitutional provisions already on the books in 1866 or state constitutional amendments seriously considered in close proximity to $1866 \mathrm{had}$ less stringent grand jury rules than those prescribed by the Fifth Amendment. Yet these gaps were never discussed, leading Fairman to argue that incorporation could not have been intended. ${ }^{232}$ Once again, I shall give the man some rope:

[A]n episode [from the Ilinois constitutional convention of 1869-70] argues very persuasively that there was no contemporary understanding that the Fourteenth Amendment had incorporated the Bill of Rights. ... [R]esolutions were offered looking to the abolition of the grand jury, ... [leading Orville H. Browning] to urge the retention of the grand jury, "to which our ancestors had been accustomed" even before the foundation of our nation. Evidently he put all his strength into the speech. But he never so much as suggested that the Fourteenth Amendment incorporated the federal Bill of Rights and thus had fastened the grand jury upon the several states.

Another delegate, James McCoy, spoke with deep feeling of this "bulwark," this "wall of defense," this "sheet-anchor of our liberties" [yet failed to argue explicitly that the Fourteenth Amendment incorporated the Fifth] ....

....

... If there was any idea among informed men in Michigan that the Fourteenth Amendment incorporated the Fifth, surely counsel would raise the point in appealing some conviction. ... [T] his is more significant than a strong decision, since in criminal cases even the most forlom hope would have been pursued. ${ }^{233}$

231. Fairman, supra note 113 , at $82-83$.

232. Id. at 84-85 (Connecticut), 97 (Ohio), 98-100 (Illinois), 101 (Kansas), 103 (Missouri), 106 (Indiana), 110-11 (Wisconsin), 115-16 (Michigan), 123 (Nebraska), 125 (California).

233. Id. at 98-100, 116 (citation omitted). 
All this seems to be very impressive anti-incorporation evidence indeed - until, that is, one gives the matter the slightest thought. If Fairman's claim was that Section One was utterly meaningless, imposing no obligations whatsoever on states, these data points would indeed fit the hypothesis. Of course, Fairman wisely avoided this outlandish claim, arguing instead that Section One simply required fundamental fairness and ordered liberty. But if the debate is between incorporation and fundamental fairness-between Black and Frankfurter-the silence Fairman trumpets becomes background noise with no resolving power whatsoever. If Orville Browning and James McCoy failed to argue that the Fourteenth Amendment "incorporated" the Fifth, they equally failed to argue that it required ordered liberty and fundamental fairness. Yet such an argument would have buttressed their claims that the grand jury should be retained because the institution was fundamental-"a wall of defense" "to which our ancestors had been accustomed," a "bulwark," a "sheet-anchor of our liberties." Clearly an institution as venerable and widespread as the grand jury, with roots in the mythic "ancient constitution" of England and in force in 1866 in all but a handful of states, could be plausibly claimed to be implicit in ordered liberty. Even if such an argument was not a knock-down winner, it was more than a "forlorn hope." Yet Fairman's vaunted "informed men in Michigan" did not raise this argument either. They simply did not speak to the Fourteenth Amendment at all, and thus their silence, interesting as it may be, has no legal resolving power between Black and Frankfurter.

Fairman's anachronistic hostility to grand juries ${ }^{234}$ led him to dismiss the possibility that these bodies might have been seen as "fundamental" in the midnineteenth century; but consider the words of Massachusetts Chief Justice Lemuel Shaw in a leading state court opinion authored less than a decade before the Fourteenth Amendment. The grand jury, said Shaw, was a "fundamental principle[] of free government"-one of the "ancient immunities and privileges of English liberty."235 Shaw also argued that the placement of a given right in "a bill of rights," state or federal, was itself evidence of its "fundamental" nature ${ }^{236}$-an argument which, if taken seriously, causes Fairman's approach to collapse into incorporation.

But Fairman's problems are only beginning. Forget about the privileges or immunities clause for a moment. Whatever else it does or does not require, Section One undeniably mandates that states follow "due process of law." Now this phrase had a rich tradition, going back to Sir Edward Coke's famous commentaries on Magna Charta, where the great Lord Chief Justice defined the core meaning of the phrase as "indictment or presentment of good and lawfull men"-i.e., a grand jury. ${ }^{237}$ American lawyers were intimately familiar with

234. Id. at $82-83,111,137$.

235. Jones v. Robbins, 74 Mass. (8 Gray) 329, 343-44 (1857) (emphasis added).

236. Id. at 340 .

237. EDWARD COKE, THE SECOND PART OF THE INSTITUTES OF THE LAWS OF ENGLAND *50-51. 
Coke's definition. Many citations could be drawn from seventeenth- and eighteenth-century sources, including Penn, Adams, and Hamilton, ${ }^{238}$ but for our purposes the major nineteenth-century legal authorities are even more significant. Here is what Joseph Story wrote in his influential Commentaries on the Constitution:

Lord Coke says, that [the words by the law of the land] mean by due process of law, that is, without due presentment or indictment, and being brought in to answer thereto by due process of the common law. So that this clause [i.e., the due process clause of the Fifth Amendment] in effect affirms the right of trial according to the process and proceedings of the common law. ${ }^{239}$

Early editions of Chancellor Kent's Commentaries on American Law are even more emphatic: "The words by the law of the land, as used in magna char$t a$... are understood to mean due process of law, that is, by indictment or presentment of good and lawful men; and this, says Lord Coke, is the true sense and exposition of those words."240

In perhaps the most famous abolitionist opinion of the antebellum era, the 1854 case of In re Booth ${ }^{241}$ the Wisconsin Supreme Court quoted this excerpt from Kent verbatim in a key passage holding that Congress' Fugitive Slave Act was unconstitutional (a holding decisively reversed by the Taney Court when the case finally reached it under the name of Ableman v. Booth ${ }^{242}$ ).

So too, in the 1857 case of Jones $v$. Robbins, Lemuel Shaw not only cited Kent and Story, but went on to hold that the words of the Massachusetts Constitution, echoing Magna Charta, required grand juries in all cases involving infamous punishment: "Lord Coke himself explains his own meaning by saying, 'the law of the land,' as expressed in Magna Charta, was intended due process of law, that is, by indictment or presentment of good and lawful men."243 Consider also the language of Alvan Stewart in one of the leading anti-slavery tracts of the antebellum era, an 1837 essay that Professor tenBroek has identified as a major source of Republican thought in the 1860's:

238. See 3 PAPERS OF ALEXANDER HAMIITON 485 (Harold C. Syrett \& Jacob E. Cooke eds., 1962) (1784 "Letter from Phocion"), quoted in Amar, supra note $f$, at 1190 n.262; A.E. DICK HOWARD, THE ROAD FROM RUNNMMED 158-59, 422 (1968).

239. 3 STORY, supra note $50, \S 1783$ (citations omitted).

240. 2 JAMES KENT, COMMENTARIES ON AMERICAN LAW 13 (New York, Clayton \& Van Norden, 2d ed. 1832) (citations omitted).

241. In re Booth, 3 Wis. 1, 66 (1854).

242. Ableman v. Booth, 62 U.S. (21 How.) 506, 526 (1858).

243. Jones v. Robbins, 74 Mass. (8 Gray) 329, 343, 346 (1857). For similar discussions linking due process with grand jury indictment, see State v. Keeran, 5 R.I. 497, 505-06 (1858); State v. Paul, 5 R.I. 185, 197 (1858); Greene v. Briggs, 10 F. Cas. 1135, 1140 (C.C.D.R.I. 1852) (No. 5764) (Curtis, Circuit J.); Taylor v. Porter, 4 Hill 140, 146 (N.Y. Sup. Ct. 1843). 
[N]o lawyer in this country or England, who is worthy of the appellation, will deny that the true and only meaning of the phrase, "due process of law," is an indictment or presentment by a grand jury, of not less than twelve, nor more than twenty-three men; a trial by a petit jury of twelve men, and a judgment pronounced on the finding of the jury, by a court. ${ }^{244}$

It need not be argued that due process in 1866 meant only grand juries-Story and Stewart seemed to think otherwise; later editions of Kent followed suit; and, of course, Murray's Lessee also suggested a broader understanding. (There are also questions about redundancy if we assume that the Fifth Amendment's due process clause merely replicated its grand jury clause.) We need not even say that due process in 1866 necessarily included a grand jury requirement; ${ }^{245}$ it is enough to say that the argument was a very strong one indeed, supported by eminent legal authorities on both sides of the Atlantic. ${ }^{246}$ Yet Fairman's "informed men in Michigan," Illinois, and elsewhere did not apparently even pause to consider even this eminently plausible reading of the due process clause of the Fourteenth Amendment.

What does this prove? Not that the words "due process" never meant grand juries; for we have seen far too much contrary evidence. Not even that the meaning of "due process" miraculously changed in 1866 , for it would take more than uninformed and unreflective silence to prove this. Rather, Fairman's own data clearly show that, contrary to his workhorse assumptions, many informed men simply were not thinking carefully about the words of Section One at all. ${ }^{247}$ And the upshot of course is that silence alone is a dubious key to unlocking the meaning of Section One. ${ }^{248}$

Nor can it be argued that silence in fact demonstrates that Section One meant nothing (the outlandish position Fairman wisely eschewed). Much of the silence Fairman finds crucial came not from state legislatures ratifying the Amendment, but from subsequent state conventions and the like. And even

244. ALVAN STEWART, A CONSTTTUTIONAL ARGUMENT ON THE SUBJECT OF SLAVERY (1837), reprinted in TENBROEK, supra note 64, at 281, 283.

245. $C f$. Rowan v. State, 30 Wis. 129 (1872) (rejecting claim that "due process" requires grand juries in unique context of state constitutional amendment eliminating specific reference to grand jury while substituting general due process language).

246. Justice Frankfurter once claimed that the due process clause would be an "extraordinarily strange" way of requiring grand juries. Adamson v. California, 332 U.S. 46, 63 (1947) (Frankfurter, J., concurring). What seems even stranger, however, is Frankfurter's apparent ignorance of the history of the phrase given all his breastbeating about Anglo-American legal traditions.

247. For a possible explanation, see infra note 270 .

248. In light of Fairman's pointed emphasis on Orville Browning's failure to invoke the Fourteenth Amendment in 1869-70, perhaps some additional details that Fairman omitted should be noted. In 1866, while the Amendment was still pending, Browning, as President Johnson's Secretary of Interior, led the Administration's charge against ratification. In a widely influential document, Browning argued that the Amendment's due process clause would "subordinate the State judiciaries to Federal supervision" and "totally annihilate the independence and sovereignty of State judiciaries in the administration of State laws." CURTIS, supra note 106, at 151-52. These facts put Browning's later conduct in a rather different light from that offered by Professor Fairman. 
during the ratification process, silence about a provision did not magically erase it from the text. If it did, we would have to blot out many key provisions of the original Constitution, not to mention the original Bill of Rights.

\section{b. Ratification Silence More Generally}

But even if the silence Fairman trumpeted has little power to resolve the incorporation debate, we should stop to consider what this silence tells us about both the Fourteenth Amendment and the Bill of Rights. Let us begin by taking seriously the analogy between the original Constitution and the Fourteenth Amendment. Many key provisions of the original document received relatively little attention during ratification simply because there were so many other important things to talk about. The same was true of the Fourteenth Amendment. The point is not simply quantitative-the five sections of the Fourteenth Amendment contain about as many words as the first ten amendments put together-but qualitative. The Fourteenth Amendment proposed nothing less than a comprehensive blueprint for the Reconstruction-the Re-Constitution- of a nation torn asunder by the Civil War. ${ }^{249}$ (Hence the Amendment's gestation in the Joint Committee on Reconstruction.)

Though twentieth-century readers rarely look past the key sentence of Section One, politicians of the day who did the proposing and ratifying saw other provisions as more important. Section Two laid down new rules for representation in Congress, and Section Three determined which Southern leaders would be eligible to hold elective office, state or federal. Taken together, these two provisions could profoundly shape the configuration of political power in America. Thus, even in the Fourteenth Amendment, structural issues predominated. Though Thaddeus Stevens opened his formal exposition of the Amendment by briefly noting that Section One would reverse the Barron rule, ${ }^{250}$ he devoted far more attention to later sections that sought to determine who would control the country in the critical years ahead: "The second section I consider the most important in the article." ${ }^{.251} \mathrm{~A}$ few days later when a draft of Section Three came under fire, Stevens responded:

Without that, [the Amendment] amounts to nothing. I do not care the snap of my finger whether it be passed or not if that be stricken out. Before another Congress shall have assembled here, and before [the rest of the Amendment] can be carried into full effect, there will be no friends of the Union left on this side of the House to carry it out

249. See, e.g., MALTZ, supra note 145, at 79-81. Various Democrats in Congress objected unsuccessfulIy to this Republican bundling of separable issues. See JAMES, supra note 201, at 148-49.

250. Quoted supra text accompanying note 197.

251. CONG. GLOBE, 39th Cong., 1st Sess. 2459 (1866). 
... [T]he House will be filled with yelling secessionists and hissing copperheads. Give us the third section or give us nothing. ${ }^{252}$

The ratification debates confirm Stevens' views about the importance of Sections Two and Three, though of course Americans disagreed sharply about whether these provisions commended or condemned the Amendment. ${ }^{253}$

In addition, the Amendment gave rise to fierce debates over issues not presented on the face of the document, but inextricably intertwined with it: the legitimacy of the rump Congress that had proposed the Amendment; the legality of various efforts to condition Southern readmission to Congress on the Amendment's ratification; the exclusion of Democrats from key caucuses discussing the Amendment; and the Congress' failure to "present" the Amendment to President Andrew Johnson. ${ }^{254}$

All this brings us to a second similarity between the original Constitution and the Fourteenth Amendment: partisan feeling ran high in both ratification periods. In 1787 and 1788, partisanship led Federalists to vote quickly and quietly in those state conventions where they had the votes, leaving relatively little record of their formal deliberations. But in the state conventions of Virginia, Massachusetts, New York, and North Carolina, Anti-Federalists and fencesitters constituted an initial majority of the delegates, obliging Federalists to do much more explaining. In 1866, the Thirty-ninth Congress followed the Philadelphia Convention model by shrouding early deliberations in the secrecy of the Joint Committee on Reconstruction. Just as Americans in 1787 had waited with increasing apprehension for the word from Philadelphia, people in 1866 impatiently looked for white smoke to emerge from the mysterious Joint Committee conclave. When official proposals did finally issue, their public exposition by leading architects like Bingham, Howard, and Stevens received special attention. But as in the 1780's, partisanship impoverished deliberation. Many of the key discussions in Washington "were carried on not in the legal Senate of the United States, but in a party meeting"255 from which Democrats were excluded. And during the ratification debates, many Republicans again kept silent in public deliberations, content that they had the votes to pass the Amendment and fearful that any statement might provide Democrats with political ammunition. ${ }^{256}$

252. Id. at 2544. Section Three was later amended. Id. at 2869; JAMES, supra note 201, at 142.

253. CURTIS, supra note 106, at 13-15, 131; FLACK, supra note 146, at 208-09; KENDRICK, supra note 146, at 348-52; MALTZ, supra note 145, at 93; Avins, supra note 107, at 9; Crosskey, supra note 44, at 112; see also ALAN P. GRIES, DEMOCRACY AND THE AMENDMENTS TO THE CONSTITUTION 44-47 (1987) (noting centrality of Sections Two and Three in House and Senate debates). In retrospect, because of underenforcement, evasion, and amnesty, these provisions ended up playing a much smaller role than originally anticipated.

254. See NELSON, supra note 64, at 93-96; JOSEPH B. JAMES, THE RATIFICATION OF THE FOURTEENTH AMENDMENT (1984).

255. JAMES, supra note 201, at 150; see also FLACK, supra note 146, at 121 .

256. CURTIS, supra note 106 , at 6 . 
So much then for what Fairman's silence tells us about the Fourteenth Amendment. What does it say about the Bill of Rights? Mainly that the Bill was relatively uncontroversial in 1866. As Michael Kent Curtis and William Winslow Crosskey have painstakingly proved, the vast majority of Republican leaders in 1866 were contrarians. ${ }^{257}$ Some, like Bingham, were highly conscious of Barron, while others had apparently never heard of the case. Yet all could agree that Bingham's Section One was simply declaratory of preexisting rights and freedoms of citizens, many of which had already been declared by the Fathers. ${ }^{258}$ The biggest Section One debate among Republicans was not what the words meant, but whether the words were necessary, given that the rights they protected already existed. Thus, a committee of the Massachusetts legislature opposed the Fourteenth Amendment because existing Amendments, including the First (which of course spoke explicitly of Congress), already "cover[ed] the whole ground" of Section One. ${ }^{259}$ Given that most Republicans viewed Section One as declaratory, it received considerably less attention during ratification than the more radical changes proposed by later sections.

Democratic critics of the Amendment also had much easier targets than Section One. Who wants to campaign against the Bill of Rights? With a few exceptions, most notably the grand jury rules we have already considered, the substance of the federal Bill's rights and freedoms did not greatly diverge from rights already formally protected under state laws and state constitutions. Now as we have seen, the slavery experience led many states to betray their own constitutional safeguards of speech, press, personal security, and the like, but the principles themselves were deeply etched in both the popular and the legal mind. Given this, one would expect that opposition to Section One would find expression in the idiom of federalism: responsibility for preservation of citizen rights, freedoms, privileges, and immunities should not be handed over to Congress and federal courts, but should remain with the states. And this is exactly the kind of thetoric that one does find during ratification. ${ }^{260}$

Finally, we must remember that the Bill of Rights had yet to prove itself in the courtroom as a powerful brake on runaway government. The antebellum crusaders against slavery had sorely felt the lack of a federally enforceable Bill of Rights against states, but no one had seen exactly how much protection such

257. See generally id., passim; Crosskey, supra note 44.

258. In addition to the various sources quoted earlier, see, e.g., CONG. GLOBE, 39th Cong., 1st Sess. 2468 (1866) (remarks of Rep. William Kelley) ("if [provisions of Section One] are not already" in the Constitution, they should be); id. at 2539 (remarks of Rep. John Fannsworth) (privileges or immunity and due process clauses of Section One are "Teaffirmation" and "surplusage"); id. at 256 app. (remarks of Rep. Jehu Baker) (Section One is "more valuable for clearing away bad interpretations . . . of the Constitution ... than for any positive grant of new power"); id. at 340 (remarks of Sen. Edgar Cowan) (suggesting Fifth Amendment due process restricts states); id. at 1833 (remarks of Rep. William Lawrence) (similar); id. at 1151-52 (remarks of Rep. Russell Thayer) (similar).

259. H.R. Doc. No. 149, Mass. Gen. Ct. 1-4 (1867).

260. See, e.g., ANIIEAU, supra note 113, at 62-70; CURTIS, supra note 106, at 149-52; MALTZ, supra note 145, at 116; NELSON, supra note 64, at 104-09. On the possibly broad power of Congress to enforce Section One, see ANTIEAU, supra note 113 , at 40-42, 55-56. 
a Bill would in fact afford. Judicial review of Congress, though trumpeted in Marbury v. Madison, ${ }^{261}$ had little bite before 1866: the only successful invocation of the Bill of Rights against Congress in the Supreme Court was Dred Scott's malodorous dictum that exclusion of slavery from the territories violated due process. ${ }^{262}$ The truly important exercises of judicial review in the antebellum era had come at the expense of state governments, not Congress ${ }^{263}$-and Barron of course had made clear that the founders' Bill of Rights was inapplicable in state cases. Though the transformative possibilities of incorporation should have been obvious to anyone who had seen what the Marshall Court had done with the sparse words of Article I, Section 10 in cases like Fletcher v. Peck and Dartmouth College, a well-developed Supreme Court jurisprudence of the Bill of Rights had yet to emerge. Indeed, the eventual emergence of this jurisprudence in the twentieth century owes far more to the Fourteenth Amendment than to anything in the original Bill..$^{264}$

\section{Early Interpretations: In Search of Reasons}

Post-ratification discussions of the Fourteenth Amendment cannot change its meaning, but can cast light backwards. In examining early interpretations, we must not simply count noses, but weigh reasons: do any of the early interpretations of the Amendment deepen our understanding of the evidence we have seen thus far?

Here too, silence alone will prove relatively unhelpful. Consider, for example, the 1869 case of Twitchell v. Pennsylvania, where the Supreme Court brusquely dismissed claims that the state had violated various provisions of the Fifth and Sixth Amendments. ${ }^{265}$ Though neither counsel nor the Court even mentioned the newly ratified Fourteenth Amendment, various critics of Justice Black have argued that the silence alone is devasting to the incorporation thesis. Thus, Felix Frankfurter wrote in his parting memorandum in the Harvard Law Review:

[Twitchell indicates that no one] even thought of proposing that these amendments had been newly brought to bear on the States by the Fourteenth. Yet the Fourteenth's formulation and adoption had been a subject of great interest, especially to lawyers and judges, only

261. 5 U.S. (1 Cranch) 137 (1803).

262. Dred Scott v. Sandford, 60 U.S. (19 How.) 393, 450-52 (1857).

263. See, e.g., Fletcher v. Peck, 10 U.S. (6 Cranch) 87 (1810); Martin v. Hunter's Lessee, 14 U.S. (1 Wheat.) 304 (1816); McCulloch v. Maryland, 17 U.S. (4 Wheat) 316 (1819); Dartmouth College v. Woodward, 17 U.S. (4 Wheat.) 518 (1819); Gibbons v. Ogden, 22 U.S. (9 Wheat) 1 (1824); Osborn v. Bank of the United States, 22 U.S. (9 Wheat) 738 (1824); Prigg v. Pennsylvania, 41 U.S. (16 Pet.) 539 (1842).

264. I develop this theme in more detail in my forthcoming book.

265. Twitchell v. Pennsylvania, 74 U.S. (7 Wall.) 321 (1869). 
months prior to the decision of these cases. The significance of this contemporaneous understanding need not be labored. ${ }^{266}$

Raoul Berger agreed: "Oversight will not account for the omission; the Amendment had been widely discussed; bench and bar are alert to every new and relevant enactment; they would not be oblivious to the revolution worked by

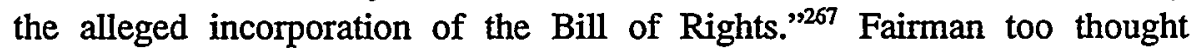
Twitchell quite impressive evidence:

[I]t did not occur to counsel for the petitioner to suggest that the Fourteenth Amendment, adopted less than a year before, had worked any change in the law applicable to the case. . . . Even though counsel for the petitioner had failed to invoke the Fourteenth Amendment, one supposes that the Court, had it been stirred by the least uncertainty, would have suggested the question and heard argument before disposing of the petition of one sentenced to death. ${ }^{268}$

But had Fairman, Frankfurter, or Berger paused to examine their supposed trump card before playing it with such flourish, they might have realized that Twitchell is in fact an embarrassing joker. Counsel explicitly argued, among other things, that Pennsylvania had violated "due process of law," but invoked only the Fifth Amendment-a (literally) fatal mistake, for the Court simply rejected the claim with a quick citation to Barron. ${ }^{269}$ But again, what does this prove? If Twitchell's silence is evidence that the Fourteenth Amendment does not incorporate earlier amendments, it is equally strong evidence that the Fourteenth does not require state due process. But in light of the plain words of the Fourteenth Amendment, this latter claim is absurd. Twitchell's silence thus proves too much — and therefore nothing at all. Or more precisely, it proves that, contrary to Berger and Fairman's glib assumptions, only "oversight will [] account for the omission;" "bench and bar are [not] alert to every new and relevant enactment;" and the Court did not pay careful attention "before disposing of the petition of one sentenced to death." ${ }^{, 270}$ Frankfurter notwithstanding, Twitchell's embarrassing silence shows no "contemporaneous understanding" and has no "significance" to the incorporation debate.

266. Frankfurter, supra note 3, at 750 .

267. BERGER, supra note 183 , at 153.

268. Fairman, supra note 113, at 132-33; see also Wallace Mendelson, Mr. Justice Black's Fourteenth Amendment, 53 MINN. L. REV. 711, 721 (1969).

269. 74 U.S. (7 Wall.) at 321, 323-26.

270. Twitchell is perhaps explicable as an unthinking reflection of the notion that Section One would have its main application in Southern states. See Fairman, supra note 113, at 112; BERGER, supra note 183, at 150-55; BERGER, FOURTEENTH AMENDMENT, supra note 139, at 38-39. But surely the Amendment as written applies to all states, North and South, as later (more self-conscious) courts have made undeniably clear. Thus to understand and explain Twitchell is not to justify it, much less use it as a springboard for serious Fourteenth Amendment analysis, as Frankfurter and company appear to. 
When we turn instead to what important decisionmakers actually did say when they focused on the relationship between the Fourteenth Amendment and the Bill, we find powerful confirmation of incorporation. Over and over in the years between 1868 and 1873, various members of Congress, both Democrat and Republican, suggested that the Bill of Rights defined paradigmatic privileges and immunities of Americans that no state could abridge and that Congress could protect by legislation under Section Five of the Fourteenth Amendment. This was no idle chatter, for Congress in fact legislated on the basis of this understanding. ${ }^{271}$

Perhaps the most illuminating case arising under this congressional legislation was the 1871 circuit court case, United States v. Hall. In the course of deciding whether Congress had power to legislate under Section Five, Judge (later Justice) William Woods had to confront the words of Section One. His conclusion plainly supported incorporation: "We think, therefore, that the ... rights enumerated in the first eight articles of amendment to the constitution of the United States are the privileges and immunities of citizens of the United States."272 But it is Woods' reasoning that is most illuminating. Like Rawle, Lumpkin, Shaw, Howard, Wilson, and many others, Woods treated rights declared in the Constitution as ipso facto fundamental, following the classic methodology of finding the common law:

What are the privileges and immunities of citizens of the United States here referred to [in Section One]? They are undoubtedly those which may be denominated fundamental; which belong of right to the citizens of all free states, and which have at all times been enjoyed by citizens of the several states which compose this Union.... Corfield $v$. Coryell. Among these we are safe in including those which in the constitution are expressly secured to the people, either as against the action of the federal or state governments. ${ }^{273}$

271. See generally CuRTIS, supra note 106 , at 154-70. Professor Fairman tried to point to various congressional decisions between 1866 and 1870 that he claimed were implicitly inconsistent with incorporation. Fairman, supra note 113, at 122-32. In admitting or readmitting states, Congress (claimed Fairman) appeared to approve without comment various state constitutions that did not perfectly comport with the federal Bill of Rights. Once again, Fairman's chief evidence focused on silence about grand juries. As we have already seen, this argument proves nothing more than the silliness of Fairman's method in drawing strong inference from mere silence. What's more, the alleged inconsistencies Fairman points to are truly de minimis in light of the basic facial consistency of these state constitutions with the privileges and immunities of the federal Bill of Rights. Given this basic consistency and the centrality of many other factors in the (re)admission process, it is unsurprising that little attention was paid to microscopic details about the precise incidents and triggers of grand juries.

272. United States v. Hall, 26 F. Cas. 79, 82 (C.C.S.D. Ala. 1871) (No. 15,282).

273. Id. at 81. Several early federal prosecutors seemed to follow Wood's approach. See ROBERT J. KACZOROWSKI, THE POLTTICS OF JUDICIAL INTERPRETATION: THE FEDERAL COURTS, DEPARTMENT OF JUSTICE, AND CIVIL RIGHTS, 1866-1870, at 125-30 (1985); see also State ex rel. The St. Joseph \& Denver City R.R. v. Commissioners of Nemaha County, 7 Kan. 542, 555 (1871) (Brewer, J., dissenting) (describing bill of rights as "those essential truths, those axioms of civil and political liberty upon which all free governments are founded"); State ex rel. Liversey v. Judge of Civil Dist. Court, 34 La. Ann. 741, 743 (1882) (bill of rights "declaratory of the general principles of republican government, and of the fundamental rights of the citizen"). 
Several months before Hall, Woods had held Circuit Court with Justice Joseph Bradley in New Orleans, where they heard the Crescent City Live-stock Case. In this case, the two judges had avoided a comprehensive definition of "the essential privileges which belong to a citizen of the United States, as such," but had equated them with "fundamental principles of free government." ${ }^{2774}$ No specific mention was made of the Bill of Rights, but Bradley's 1871 correspondence with Woods showed that the Justice endorsed Hall's methodology and result. ${ }^{275}$

Bradley's position became public in 1873, when he got a second crack at the Crescent City case, then on appeal as one of the famous Slaughter-House Cases. ${ }^{276}$ The cases provided the Supreme Court its first opportunity to carefully reflect and opine on the Fourteenth Amendment, and Bradley in dissent offered the most comprehensive analysis of the issue that most concerns us: the relationship between the new Amendment and the rights recognized in the pre-1866 Constitution. Wrote Bradley:

The people of this country brought with thern to its shores the rights of Englishmen .... [Bradley then cited and discussed "fundamental rights" found in, among other places, Magna Charta, Blackstone's Commentaries, and Justice Washington's catalogue of common law rights in Corfield.] But we are not bound to resort to implication, or to the constitutional history of England, to find an authoritative declaration of some of the most important privileges and immunities of citizens of the United States. It is in the Constitution itself. ${ }^{277}$

Bradley proceeded to offer a representative sample of the "privileges and immunities of citizens of the United States" declared in the pre-1866 Constitution, including the ban against bills of attainder and ex post facto laws, and the rights to habeas corpus, trial by jury, free exercise, free speech, free press, free assembly, and security against unreasonable searches. ${ }^{278}$ Bradley then resumed his analysis of unwritten fundamental law, but later returned to the Constitution, concluding as follows:

Admitting ... that formerly the States were not prohibited from infringing any of the fundamental privileges and immunities of citizens of the United States, except in a few specified cases, that cannot be

274. Live-stock Dealers \& Butchers' Ass'n v. Crescent City Live-stock Landing \& Slaughter-House Co., 15 F. Cas. 649, 652 (C.C.D. La. 1870) (No. 8408).

275. KACZOROWSKI, supra note 273, at 16 ("[P]ortions of [Woods' opinion in Hall] were verbatim copies of Justice Bradley's letter.").

276. See also Blylew v. United States, 80 U.S. (13 Wall.) 581, 596 (1871) (Bradley, J., dissenting) (Civil Rights Bill of 1866 designed to protect blacks in "having firearms, . . . exercising the functions of a minister of the gospel, ... [in] being taught to read and write," and against "laws which subjected them to cruel and ignominious punishments not imposed upon white persons").

277. 83 U.S. (16 Wall.) 36, 114-18 (1873) (Bradley, J., dissenting) (emphasis added).

278. Id. at 118 . 
said now, since the adoption of the fourteenth amendment. In my judgment, it was the intention of the people of this country in adopting the amendment to provide National security against violation by the States of the fundamental rights of the citizen. ${ }^{279}$

Like Woods, Bradley apparently understood all rights and privileges in the Bill of Rights as ipso facto fundamental, but Bradley went beyond Woods by adding to the list various privileges and immunities declared in the original Constitution. In the process, Bradley hinted at a more refined version of incorporation, apparently based on whether a given provision of the pre-1866 Constitution had roots as a common law privilege or immunity. Thus, Bradley included both the habeas clause from Article I and the jury rights in Article III on his list, yet appeared pointedly to exclude nonestablishment when listing First Amendment rights. We shall return to this hint later.

Justice Bradley's opinion was joined by Justice Swayne, but Swayne went on to add some rather confusing remarks of his own. Justices Field and Miller also wrote opinions in Slaughter-House, but neither provided a careful analysis of incorporation. Field's discussion of privileges and immunities simply stressed Corfield, the common law, and fundamental rights without mentioning the Bill, probably because none of its provisions was directly implicated by the facts at hand. ${ }^{280}$ Bradley at least saw no contradiction between Field's approach and his own, for he joined Field's opinion. Justice Miller's opinion for the Court did not squarely address Bradley's incorporation analysis, offering only the following cryptic remark: "The right to peaceably assemble and petition for redress of grievances, the privilege of the writ of habeas corpus, are rights of the citizen guaranteed by the Federal Constitution.,"281 Read for all it might be worth, this passage could imply that all the rights and freedoms declared in the pre-1866 Constitution were "privileges and immunities of citizens of the United States," that no state could thereafter abridge. ${ }^{282}$ The conventional reading, however, is far more narrow: Miller had in mind only state interference with efforts to assemble and petition the federal government, and to secure habeas relief on the basis of federal laws in federal courts. ${ }^{283}$

The conventional reading of course falls far short of incorporation, but if we are looking for reasons rather than counting noses, Miller's opinion has nothing to offer. Miller's one-liner never explains why other rights and freedoms of the pre-1866 Constitution are somehow not privileges and immunities of citizens of the United States at the center of Section One's letter and spirit. What's more, the conventional reading has the effect of rendering the privileges

279. Id. at 121-22.

280. Id. at 96-111 (Field, J., dissenting).

281. Id. at 79.

282. Cf. ELY, supra note 141, at 196 n.59 (suggesting broad incorporationist reading of Miller's language).

283. See 2 CROSSKEY, supra note 29 , at 1128-30. 
or immunities clause wholly unnecessary_-"a vain and idle enactment,"284 in the famous words of Justice Field. Clearly the supremacy clause standing alone, or as glossed by $M c C$ ulloch, ${ }^{285}$ would have sufficed to prohibit state interference with federal petitions and federal writs. Like Twitchell, then, Slaughter-House is no trump card for anti-incorporationists. If read conventionally, the majority opinion rejects not just Black's incorporation, but Frankfurter's and Fairman's ordered liberty, Berger's terms of art, and indeed every theory of Section One that gives Bingham's key clause any independent bite.

We must nevertheless keep Miller's opinion in mind, for it helps to explain the impoverishment of Fourteenth Amendment discourse in the Supreme Court over the next several generations. By strangling the privileges or immunities clause in its crib, Slaughter-House forced contrarian-minded litigants to argue that the original Bill applied against states either directly of its own force, or via the Fourteenth Amendment's due process clause. The Court continued to dismiss the former argument with a quick invocation of Barron and also regularly rebuffed the latter. If we are simply counting noses, there are lots of Justices involved, ${ }^{286}$ though a fair count would require toting up the probably larger number of incorporation-minded Congressmen in the years immediately after ratification. But once again, if we are looking for reasons-for analysis of the letter and spirit of the privileges or immunities clause-we find next to nothing in the High Court between Slaughter-House and Hugo Black's heroic re-examination and resurrection of the clause in his famous 1947 dissent in Adamson v. California. In the vast wasteland between Bradley and Black, only four Supreme Court landmarks stand out: John Randolph Tucker's celebrated oral argument in Spies v. Illinois in 1887; Justice Field's eventual decision (joined by the first Justice Harlan and Justice Brewer) to embrace Tucker's analysis in the 1892 case, O'Neil $v$. Vermont; and Justice Harlan's subsequent

284. 83 U.S. (16 Wall.) at 96 (Field, J., dissenting).

285. McCulloch v. Maryland, 17 U.S. (4 Wheat.) 316 (1819) (striking down state interference with federal bank).

286. See, for example, the list of cases compiled in Frankfurter, supra note 3. Upon close inspection, the list is less impressive than it looks. Many of the cited passages simply reject the claim that a provision of the original Bill applied of its own force against states-technically, a quite different claim from one based on incorporation (or what have you) via the Fourteenth Amendment. This is no mere pedantic quibble, for the Court took this pleading technicality quite seriously for many years, as illustrated by both Twitchell, 74 U.S. (7 Wall.) 321 (1869) (discussed supra text accompanying notes 265-270), and Palmer v. Ohio, 248 U.S. 32, 34 (1918) (dismissing Fifth Amendment just compensation claim against state as "palpably groundless" even though Court had earlier incorporated "just compensation" principle into Fourteenth Amendment, see Chicago, B \& Q R.R. v. Chicago, 166 U.S. 226 (1897)). Indeed, in the most important case Frankfurter himself cites, the Court, after quickly dismissing the Barron argument, treats the same basic claim, repackaged as a Fourteenth Amendment argument, with much greater attention. Spies v. Illinois, 123 U.S. 131, 165-67 (1887). 
reaffirmations of this approach in Maxwell v. Dow and in Twining v. New Jersey in 1900 and 1908 respectively. ${ }^{287}$

Justice Black in Adamson relied on each of these landmarks, apparently believing that they supported his brand of mechanical incorporation. ${ }^{288}$ Yet the words of Bradley, Tucker, Field, and Harlan in fact support a considerably more refined version of incorporation - a version that synthesizes the strengths of the three modern positions on incorporation that have dominated legal discourse since Adamson: Hugo Black's total incorporation model, William Brennan's selective incorporation approach, and Felix Frankfurter's anti-incorporationist emphasis on fundamental fairness.

It is now time, with the help of Bradley, Tucker, Field, and Harlan, to elaborate this synthesis.

\section{THE HARD PART OF INCORPORATION}

\section{A. The Problem: Fitting the Constitution's Pegs into Reconstruction Holes}

The easy case for incorporation cannot be easily rebutted as a matter of either text or legislative history. Nevertheless, incorporation raises many more difficulties than Black admitted. The major problem is structural: the original Bill of Rights and the Fourteenth Amendment feature very different constitutional architectures. Sensibly fitting the two together requires far more judicial artisanship-far more judgment-than Black's rhetoric suggested.

As I have tried to show elsewhere, the 1789 Bill tightly knit together citizen rights and state rights, ${ }^{289}$ but the 1866 Amendment unraveled this fabric, vesting citizens with rights against states. The original Bill also focused centrally on empowering the people collectively against government agents following their own agenda. ${ }^{290}$ The Fourteenth Amendment, by contrast, focused on protecting minorities against even responsive, representative, majoritarian government. Over and over, the 1789 Bill proclaimed "the right[s]" and "the powers" of "the people"291_phrases conjuring up civic republicanism, collective political action, public rights, and positive liberty. The complementary phrase in the 1866 Amendment-"privileges or immunities of citizens"--indi-

287. Spies, 123 U.S. at 150-52 (oral argument of John Randolph Tucker); O'Neil v. Vermont, 144 U.S. 323, 360-64 (1892) (Field, J., dissenting); Maxwell v. Dow, 176 U.S. 581, 605-17 (1900) (Harlan, J., dissenting); Twining v. New Jersey, 211 U.S. 78, 114-27 (1908) (Harlan, J., dissenting). The foregoing passages are identified as "landmarks" not because they support my analysis (although they do), but because they constitute virtually the only extended discussion in the United States Reports between Slaughter-House and Adamson of the relationship (or lack thereof) between the federal Bill and the privileges or immunities clause.

288. Adamson v. California, 332 U.S. 46, 120-23 (1947).

289. Amar, supra note $f$.

290. See id.

291. See id. at 1210 (noting that no phrase appears in more of first 10 amendments than the phrase, "the people"); supra note 151 (listing references to "the people" in the Bill). 
cates a subtle but real shift of emphasis, reflecting a vision more liberal than republican, more individualistic than collectivist, more private than public, more negative than affirmative.

Or at least, so I shall argue in detail in a forthcoming book on the Bill of Rights and the Fourteenth Amendment. For now, a single example suffices to illustrate the analytic difficulties posed by incorporation: the right to keep and bear arms. The 1789 instantiation of this right was intimately connected with federalism concerns about a federally controlled standing army that might seek to overawe state-organized militias. ${ }^{292}$ By contrast, in 1866, John Bingham, Jacob Howard, Thaddeus Stevens, and company were hardly in the mood to rail against a federal standing army; these men, after all, wanted to use precisely such an army to reconstruct recalcitrant Southern states. How then, to square their understanding of "the right ... to keep and bear arms" with the rather different vision of the Second Amendment's Anti-Federalist architects, George Mason and Elbridge Gerry?

The Second Amendment also focused on arms bearing as a political right akin to voting. Thus, a strong argument could be made that the original Amendment protected only adult male citizens. These men, of course, constituted the "militia" of the Amendment's preamble, and we can sensibly read the phrase "the people" in the Amendment's main clause as synonymous with "the militia," thereby eliminating the grammatical and analytic tension that would otherwise exist between the two clauses. ${ }^{293}$ Such a reading also draws support from the original Constitution's use of the phrase "the people" to connote "voters"- the same adult male citizens who, roughly speaking, constituted "the militia." ${ }^{294}$ By contrast, the privileges or immunities clause spoke of all citizens, pointedly including women and children, as made clear by the words immediately preceding Bingham's key sentence defining citizens to include "[a]ll persons born or naturalized in the United States." Time and again Reconstructors in 1866 declared that Section One and its companion Civil Rights Act focused on "civil rights," not "political rights" like voting and militia ser-

292. See Amar, supra note $t$, at $1162-73$.

293. Indeed, before undergoing stylistic surgery in the Senate, the Amendment as passed by the House in 1789 read as follows: "A well regulated militia, composed of the body of the People, being the best security of a free state, the right of the People to keep and bear arms, shall not be infringed." See EDWARD DUMBAULD, THE BILL OF RIGHTS AND WHAT IT MEANS TODAY 214 (1957).

294. See Amar, supra note $\dagger$, at 1164-67 (linking refenence to "the people" in Second Amendment to references to "the people"-paradigmatically, voters-in Preamble and Article I, Section 2). 
vice. ${ }^{295}$ But how to fit that vision together with the original Second Amendment?

Put another way, the Second Amendment fused together arms-bearing, militia service, and (implicitly) political participation, yet the overall architecture of the Fourteenth Amendment seems to pull them apart, with civil rights at the core of Section One, and political rights featured separately in Section Two. (We should note that Section Two appeared to preserve the linkage between the militia and voting. Though the word "militia" went unspoken, the section defined a state's presumptive electorate as "male citizens twenty-one years of age" or older.) What changes, if any, must "the right . . . to keep and bear arms" undergo if it is to be redefined as an essentially "civil" right?

\section{B. The Solution: Refined Incorporation}

Thus far, the Supreme Court has avoided these puzzles by refusing to review cases involving the possible incorporation of the Second Amendment, ${ }^{296}$ but analogous questions can be raised about other provisions of the original Bill. Finding sensible answers will require nothing less than a new model of incorporation. To see why, we need only briefly review the two selfproclaimed incorporation models that have emerged on the modern Court.

\section{Total and Selective Incorporation Revisited}

Begin with Hugo Black's insight that all the "privileges" and "immunities" of "citizens" in the original Bill should be protected against state action. Yet, the words of Section One are not limited to the Bill; they must also encompass all the privileges and immunities of the original Constitution-most obviously, the privilege of habeas corpus. Of course, not all of the original Constitution's

295. See, e.g., Report of the Joint Committee on Reconstruction, 39th Cong., 1st Sess. 7, 12, 15 (1866) (distinguishing between "civil" and "political" rights, and linking Section One with "civil rights and privileges") (emphasis added); CONG. GLOBE, 39th Cong., Ist Sess. 476, 599, 606, 1117, 1151, 1159, 1162, 1757, 1832, 1836, 3035 (1866) (remarks of Sen. Lyman Trumbull, Reps. James Wilson, Russell Thayer, William Windom, and William Lawrence, and Sen. John Henderson) (Civil Rights Bill does not encompass political rights like voting); id. at 2542, 2766 (remarks of John Bingham and Jacob Howard) (clearly stating that Section One did not encompass right of suffage); JAMES, supra note 201, at 163 (quoting 1866 campaign speech of Thaddeus Stevens conceding that Section One "does not touch . . . political rights"); PHILADELPHIA N. AM. \& U.S. GAZETTE, Sept. 28, 1866, at 2, quoted in ANTIEAU, supra note 113, at 50-51 ("In making all native born and naturalized persons citizens, this section does not make them voters, for if it did, then would all women and minors have the right of suffrage, since they are just as much persons .... The fact that this section does not give the colored man the right of suffrage constitutes the main reason why the extreme advocates of Negro suffrage oppose the Amendment."); see also Minor v. Happersett, 88 U.S. (21 Wall.) 162 (1874) (right of suffrage not a Section One privilege or immunity); H.R. REP. NO. 22, 41 st Cong., 3d Sess. 1-4 (1871), reprinted in THE RECONSTRUCTION AMENDMENTS' DEBATES 466-67 (Alfred Avins ed., 1967) (Victoria Woodhull petition report authored by John Bingham) (similar); CURTIS, supra note 106, at 149; MALTZ, supra note 145, at 118-20.

296. See, e.g., Burton v. Sills, 248 A.2d 921 (N.J. 1968), appeal dismissed, 394 U.S. 812 (1969); Quilici v. Village of Morton Grove, 695 F.2d 261 (7th Cir. 1982), cert. denied, 464 U.S. 863 (1983). 
restrictions on federal power are pure citizen rights; some-like the habeas clause's next door neighbor, the capitation clause-are more concerned with state rights and thus awkward to incorporate against states. The original Bill of Rights mirrored the Constitution in this respect, including both state rights and citizen rights. And state rights are not obviously limited to the Ninth and Tenth Amendments-consider for example the establishment clause $e^{297}$-so Black's quick redefinition of the Bill of Rights as meaning only Amendments I-VIII will not do the trick.

More promising here is Justice Brennan's invitation to consider incorporation clause by clause, an invitation that of course needs to be extended beyond the Bill to encompass the original Constitution as well. After individualized consideration we may well decide that virtually every provision of the first eight amendments is appropriately incorporated, but Black's approach simply prejudges the issue by deciding wholesale tough questions that are best handled clause by clause. Thus, even if we decide that it does make sense to incorporate the establishment clause we must honestly confront the special problems here ${ }^{298}$ rather than sweeping them under the rug of total incorporation.

Black's total approach, however, had an obvious advantage over Brennan's selective model. Black kept faith with Section One's text and history, embracing all the Bill's privileges and immunities. In contrast, Brennan's approach seemed to countenance refusal to incorporate a right or privilege if the Justices did not deem that right "fundamental"-notwithstanding We the People's declaratory judgment that the right was so fundamental as to warrant inclusion in the Bill. While admiring the pragmatic flexibility Brennan's approach allowed ${ }^{299}$ critics condemned selective incorporation as unprincipled. Thus, Louis Henkin wrote that "[s]elective incorporation finds no support in the language of the amendment, or in the history of its adoption," and Judge Friendly went so far as to remark that "[w] hatever one's views about the historical support for Mr. Justice Black's wholesale incorporation theory, it appears undisputed that the selective incorporation theory has none." 300

To the extent selective incorporation was simply Brennan's polite way of achieving total incorporation by indirection, clause by clause, without having to overrule pre-Warren Court precedent repudiating Black, the practical difference between the two models of incorporation diminishes. And in the cases they decided, Justice Brennan and his brethren never met a right in the Bill they didn't like or deem fundamental enough to warrant incorporation. But four rights in Amendments I-VIII have remained outside the selective fold: the right

297. See Amar, supra note $t$, at 1157-60.

298. See id.

299. Henkin, supra note 130, at 76; LoUS LUSKY, BY WHAT RIGHT? 163 (1975); see also Israel, supra note 150 , at 272 \& n. 138 .

300. Henkin, supra note 130, at 77-78; Friendly, supra note 1, at 934 (citation omitted); see also CuRTIS, supra note 106, at 112 ("[1]t is difficult to see a logical basis for eliminating some guarantees but not others."); LuSKY, supra note 299, at 163 (selective incorporation has "no conceivable historical basis"). 
to keep and bear arms, the right against quartering soldiers, and the rights to grand and civil juries. For the Third Amendment, a plausible explanation for failure to incorporate is that a proper case never materialized: the right rarely arises in modern litigation. Yet as to the other three rights, the modern Court has let stand lower court decisions rejecting incorporation. ${ }^{301}$ By refusing to discuss openly why these three rights somehow were not fundamental enough to justify incorporation, the Justices have seemed to plead no contest to the critics' charge that selective incorporation was unprincipled. And indeed, as to grand juries, it does seem hard to see why this "ancient immunity and privilege" of English liberty is not embraced-doubly-by the privileges or immunities and due process clauses.

The Second Amendment poses somewhat different complications. Perhaps the Supreme Court has assumed that the Second is a purely federalism-based right of organized state militias and thus inappropriate for incorporation against states. If so, the Court's assumption rests on a dubious reading of the word "militia" and inattention to the grammar and syntax of the Amendment, which speaks of a right of "the people," not "the states." whatever the reasons for reading the Second Amendment as a states' rights provision analogous to the Tenth Amendment, there are more powerful reasons for so reading the establishment clause ${ }^{303}$ which has already been incorporated. ${ }^{304}$

\section{A New Synthesis}

But the focus on the Second Amendment suggests a different filter that leads to a new, refined model of incorporation. Instead of asking whether a given provision is fundamental or not, as Brennan suggests, we must ask whether it is a personal privilege - that is, a private right-of individual citizens, rather than a right of states or the public at large.

This question responds to the structural difficulty of incorporation yet keeps faith with Section One's letter and spirit. This question, or something like it, is obviously the filter we need once we remember that Section One incorporates "the privileges or immunities of citizens" declared in the original Constitution as well as the Bill of Rights. For how else could we filter out those Article I

301. In addition to the Second Amendment cases cited supra note 296, see, e.g., Gyuro v. Connecticut, 242 A.2d 734 (Conn.), cert. denied, 393 U.S. 937 (1968) (grand jury); Melancon v. McKeithen, 345 F. Supp. 1025 (E.D. La. 1972), aff' $d$ sub nom. Mayes v. Ellis, 409 U.S. 943 (1972) (over dissent of Douglas, J.), aff' $d$ sub nom. Davis v. Edwards, 409 U.S. 1098 (1972) (civil jury); see also Beck v. Washington, 369 U.S. 541, 545 (1962) (opinion of the Court, including Justice Brennan, endorsing longstanding Supreme Court case law that states may "dispens[e] entirely" with grand juries).

302. See Amar, supra note $\dagger$, at 1166-67.

303. See id. at 1157-60.

304. No one recognized the special awkwardness of incorporating the establishment clause better than Brennan, as shown by his special concurrence in Abington School District v. Schempp, 374 U.S. 203, 25458 (1963) (Brennan, J., concurring). 
limitations that should be incorporated, like habeas, and separate them from those that should not, like capitation (a state right) or even bicameralism (a right of the public at large)? The same filter works for the Bill of Rights, and for the same reasons. Indeed, the filter nicely combines the respective strengths of Black's and Brennan's models of incorporation. With this filter, we can preserve the textual and historical support for Black's insistence that all the Bill's privileges or immunities are indeed incorporated while accommodating Brennan's intuition that perhaps not every provision of Amendments I-VIII sensibly incorporates. This synthesis offers a principled substitute to the seeming ad hocery of selective incorporation as now practiced.

Of course, to view an entitlement as a private right is not to deny that it may have public or political significance, but only to recognize that it is a right vested in discrete individuals. For example, a publisher has a private right-a privilege - to print newspaper editorials even (indeed, especially) if the editorials take a stand on public or political matters. (Seen from another angle, the publisher's privilege is rooted in, even if not exhausted by, her private rights to her bodily liberty and her property - rights that would be violated by jails or fines.).

The Second Amendment, however, illustrates that states' rights and individual rights, "private" rights of discrete citizens and "public" rights of the citizenry generally, were sometimes marbled together into a single clause. A truly sensible and sensitive incorporation must go beyond a binary "all in" or "all out" approach to individual clauses. At times, judges must mine and refine out citizen rights from the mixed ore in which they are embedded in the 1789 Bill. And it is exactly at this point that elements of Frankfurter's analysis enter our new synthesis, for he recognized the distortions introduced by mechanical jot for jot incorporation.

Black's insistence on jot for jot state compliance followed naturally from his commitment to total incorporation (but only of Amendments I-VIm), his disdain for judicial discretion, and his belief in enforcing absolute rights in all their strictness. Harder to understand was Brennan's insistence "that once a provision of the Federal Bill was deemed incorporated, it applied identically in state and federal proceedings. ${ }^{.305}$ If judges had discretion to decide which clauses were "fundamental" and which were not, why didn't they have equal discretion to decide which doctrinal subrules of a given clause were fundamental? $?^{306}$

Of course, we have seen that the right question is not whether a clause is fundamental, but whether it is truly a private right of the citizen rather than a right of states or the public generally. So too, Frankfurter's instinct must be analogously recast. Various rules and subdoctrines associated with the original

305. Brennan II, supra note 5 , at 545 .

306. Friendly, supra note 1, at 936; Henkin, supra note 130 , at 82 . 
Bill may not incorporate jot for jot-indeed, the very metaphor of incorporation may mislead. But the reason is not that these rules and subdoctrines are not fundamental; rather, it is that they may reflect federalism and other structural concerns unique to the central government. For example, to the extent the First Amendment freedom of speech is read as an absolute, not as a matter of free speech doctrine, but for reasons of federalism rooted in a lack of enumerated congressional power in Article I, Section $8^{307}$ - to that extent, the clause does not sensibly incorporate jot for jot. An argument can also be made that major aspects of current Seventh Amendment doctrine may be driven by federalism concerns that should not be imposed on states. ${ }^{308}$ If so, refined incorporation can offer a more principled basis for retaining one of the widely hailed ${ }^{309}$ pragmatic virtues of Brennan's approach: namely, the refusal to require state courts in the late twentieth century to follow English civil jury rules circa 1791.

Indeed, as the Second Amendment illustrates, the very same words "the right ... to keep and bear arms" take on a different coloration and nuance when they are relabeled "privileges or immunities of citizens" rather than "the right of the people," and when they are severed from their association with a well-regulated militia. To recast the textual point as an historical one, the core applications and central meanings of the right to keep and bear arms and other key rights were very different in 1866 than in 1789. Mechanical incorporation obscured all this and, indeed, made it easy to forget that when we. "apply" the Bill of Rights against the states today, we must first and foremost reflect on the meaning and the spirit of the Amendment of 1866, not the Bill of 1789.

\section{A Founding Analogy}

Thus, in the very process of being absorbed into the Fourteenth Amendment, various rights and freedoms of the original Bill may be subtly but importantly transformed in much the same way the Bill of Rights transformed language it had absorbed from still earlier sources. Consider, for example, the freedom of the press. Historian Leonard Levy has piled up mounds of evidence that the phrase "freedom of the press" at common law in England and in the colonies meant only freedom from prior restraint. Since the framers of the First Amendment used the same phrase with little extended discussion, Levy suggests they must have meant to incorporate the common law doctrine jot for jot. ${ }^{310}$

307. See supra note 38 and text accompanying note 53; infra text accompanying notes 343-45.

308. I develop this theme in my forthcoming book.

309. See, e.g., LUSKY, supra note 299, at 162-63; Henkin, supra note 130, at 76; Israel, supra note 150, at 272 \& n.138; see also BLACK, supra note 4, at 36 ("[m]ost of those who object to complete incorporation of the Bill of Rights point to the Seventh Amendment" as "objectionable"); Adamson v. California, 332 U.S. 46, 63-65 (1947) (Frankfurter, J., concurring) (jaundiced view of civil juries); Fairman, supra note 113, at 82-83, 137 (similar); Griswold, supra note 15, at 166 (similar).

310. LEONARD W. LEVY, EMERGENCE OF A FREE PRESS 281 (1985). 
The argument shows more historical doggedness than legal sensitivity. In England, Parliament was sovereign. Legal rights in such a system sensibly ran only against executive and judicial officials, like licensers appointed by the Crown, rather than against Parliament itself. But in a document self-consciously based on popular sovereignty, as proudly proclaimed in the opening words of the Preamble, is it sensible to mechanically incorporate rules based on an utterly contrary premise? Don't We the Sovereign People of America necessarily have the same inherent rights of free political expression enjoyed by members of the Sovereign Parliament in England? If so, "freedom of the press" in the First Amendment necessarily means more than mere freedom from prior restraint. The prior restraint ban may indeed be part of our First Amendment, but surely that ban does not exhaust the constitutional meaning of "freedom of the press."

To put the structural point textually, the old phrase "freedom of the press" takes on new meaning when conjoined-as it never was in England or the colonies, and virtually never was in the states-with "the freedom of speech." ${ }^{\text {311 }}$ Surely the two rights in the federal Bill are in pari materia; each must be construed in relation to the other, and it would be curious if freedom of the printed word were drastically more truncated than freedom of oral expression. Yet the idea that "freedom of speech" means only freedom from prior restraint is utterly outlandish-wholly lacking in historical support and difficult even to imagine in practice. (Licensing the few printing presses that existed in the seventeenth and eighteenth centuries is one thing; but what would it mean to purport to license speakers and require official preclearance before one could open one's mouth? ${ }^{312}$ ) Rather, "freedom of speech" had a rich tradition, in England and in the states, of guaranteeing absolute freedom of speech and debate within the Sovereign legislature. ${ }^{313}$ And thus, the extension of this right to ordinary citizens in the First Amendment is indeed simply a textual recognition of the structural truth of American popular sovereignty.

Not all of this was spelled out in elaborate detail in 1789, though Madison did briefly remark on the differences between the British system and the American theory of popular sovereignty on the very day he introduced the Bill of Rights. ${ }^{314}$ Nevertheless, most twentieth-century lawyers would have little

311. Of the original 13 colonies, only Pennsylvania explicitly guaranteed "freedom of speech" for citizens in its constitution, in a provision also declaring that "freedom of the press ought not to be restrained." PA. CONST. of 1776 (Declaration of Rights), art. XI; LEVY, supra note 310, at 5. The federal Bill, of course, changed "ought" to "shall." See IRVING BRANT, THE BILL OF RIGHTS 37-42 (1965).

312. For a similar analysis, see William T. Mayton, Seditious Libel and the Lost Guarantee of a Freedom of Expression, 84 COLUM. L. REV. 91,120 n.154 (1984); Richard A. Posner, Free Speech in an Economic Perspective, 20 SUFFOLK U. L. REV. 1, 4 (1986).

313. See Amar, supra note $t$, at 1151 \& $n .96$ and sources noted therein.

314. 1 ANNALS OF CONG., supra note 31, at 453-54 (June 8, 1789). Madison returned to this theme in much greater detail a decade later in his careful exposition of the unconstitutionality of the Sedition Act. See James Madison, Report on the Virginia Resolutions (Jan. 1800), reprinted in 4 ELLIOT's DEBATES, supra note 30, at 546, 569-71; see also 4 ANNALs OF CONG. 934 (1794) (remarks of James Madison) ("If we advert to the nature of Republican Government, we shall find that the censorial power is in the people over the Government, and not in the Government over the people."). 
trouble admitting that various common law principles may have changed shape in subtle but important ways when absorbed into the Constitution and Bill of Rights. The common law, after all, is famous for its ability to adapt itself to new situations, remolding its contours to accommodate a new legal landscape.

Most lawyers today, however, have failed to reflect seriously on the analogous dynamic raised by Reconstruction's absorption of the Bill of Rights. Disciples of Black and Brennan posit an essentially mechanical process that denies the need to reshape 1789 doctrines to fit the 1866 vision; and followers of Frankfurter insist that, strictly speaking, there is no logical relationship at all between the Bill and Fourteenth Amendment. What is called for, then, is a new way of thinking about this relationship that is neither mechanical (like Black and Brennan) nor autistic (like Frankfurter) -an approach that tries to remold the provisions of the original Bill into "privileges" and "immunities" of "citizens" to fit the spirit and the architecture of the Fourteenth Amendment.

Ironically, English common law may be of great help here, for it featured expositions of many privileges and immunities with counterparts in the Bill of Rights, but without the Bill's federalism, majoritarian, and public rights glosses. To be sure, we must be wary of Blackstonian rules to the extent they are inconsistent with popular sovereignty theory-for this feature of the American Constitution was not repudiated by the Fourteenth Amendment. Nevertheless, English common law offers a crude but helpful test to sort out which aspects of the pre-1866 Constitution were indeed privileges of individuals (e.g., habeas) and which were instead structural provisions unique to the federal government and inappropriate for imposition on states (e.g., capitation and bicameralism).

\section{The Old Roots of the New Synthesis}

Though the model of refined incorporation will no doubt strike most twentieth-century lawyers as novel, it has deep historical roots. Recall, for example, that even before the Fourteenth Amendment, C.P. Van Ness argued in 1840 that certain aspects of the founders' Bill should apply to states. Van Ness pointedly eschewed total incorporation: "Each article, therefore, if not each clause, should be construed simply according to its own nature, and the terms in which it may be expressed."315 And in considering the "nature" of each clause, Van Ness proposed that courts distinguish between mere "limitations of governmental power," the prototype of which, he thought, was the Tenth Amendment, and "declarations of rights" inherent in the individual, like the right to due process. ${ }^{316}$ The former did not sensibly apply against the states, but the latter did, argued Van Ness. Though Van Ness did not elaborate this distinction in great detail, later commentators would.

315. Holmes v. Jennison, 39 U.S. (14 Pet.) 540, 555 (1840) (oral argument).

316. Id. at 555-57. 
Consider, for example, John Bingham's remarks in 1859: "“privileges and immunities of citizens in the several States' [do not include] rights and immunities of the several States." ${ }^{, 317}$ When Bingham later framed his proposed amendment, he used words that spoke of rights of citizens in contradistinction to rights of the several states; of private rights (for that is what the word "privileges" quite literally means) like habeas in contradistinction to public rules of government structure like bicameralism. And although it would be a mistake to read too much into the subtle vagaries of expression in the Thirty-ninth Congress, virtually no one spoke of mechanically incorporating the Bill of Rights as such. Formulations speaking of "the great fundamental rights" possessed "by the citizen" and "embraced in the bill of rights"318 were typical. Indeed, both Bingham and Howard seemed to redefine "the Bill of Rights" as encompassing only the first eight rather than ten amendments, presumably because they saw the Ninth and Tenth Amendments as federalism provisions. ${ }^{319}$ But even after slicing off Amendments IX and X, Bingham and Howard, unlike Black, avoided the language of jot for jot incorporation, speaking instead of "the privileges and immunities of citizens ... defined in," and "the personal rights guarantied and secured by," the "first eight amendments. ${ }^{3320}$ Even more significant, members of the Thirty-ninth Congress regularly linked the Bill of Rights with the classic common law rights of individuals exemplified in Blackstone, Corfield, and the Civil Rights Act of $1866 .{ }^{321}$

Bradley's Slaughter-House opinion also invoked Blackstone, Corfield, and the common law alongside the Bill of Rights. Let us examine more carefully his nonexhaustive catalogue of "privileges or immunities of citizens" derived from the pre-1866 Constitution:

the right of habeas corpus, the right of trial by jury, of free exercise of religious worship, the right of free speech and a free press, the right peaceably to assemble for the discussion of public measures, the right to be secure against unreasonable searches and seizures, and above all, and including almost all the rest, the right of not being deprived of life, liberty, or property, without due process of law. ${ }^{322}$

The order of this list shows that Bradley is tracking the order in which various privileges and immunities are mentioned in the pre-1866 Constitution. Habeas comes first (from Article I, Section 9), and then jury trial-not from the Sixth Amendment, but from Article III-followed by a paraphrase of the

317. CoNG. GLOBE, 35th Cong., $2 d$ Sess. 984 (1859) (emphasis added).

318. CONG. GLOBE, 39th Cong., 1st Sess. 1294 (1866) (remarks of Rep. James Wilson) (emphasis added).

319. Quoted supra note 195 and text accompanying notes $116,194,198$.

320. Quoted supra text accompanying note 198 (emphasis added).

321. See supra text accompanying notes 229-30.

322. The Slaughter-House Cases, 83 U.S. (16 Wall.) 36, 118 (1873) (Bradley, J., dissenting) (emphasis omitted). 
First Amendment absent the establishment clause. Though Bradley does not explicate his implicit filter, it seems that he is influenced by common law categories of personal liberty and security. Such a filter would explain why, for example, jury trial is taken from Article III, but bicameralism is not taken from Article I. This implicit filter might also explain the omission of the establishment clause, which, unlike its First Amendment companions, does not so obviously resonate with common law rights of personal property, personal security, and bodily liberty.

Further support for this reading of Bradley comes from an adjoining passage where he summarized "the personal privileges and immunities of citizens" that were explicitly protected against state action by the original Constitution: "The States were merely prohibited from passing bills of attainder, ex post facto laws, laws impairing the obligation of contracts, and perhaps one or two more. ${ }^{, 323}$ Left out of Bradley's filtered version of Article I, Section 10 were the prohibitions that "No state shall enter into any Treaty, Alliance, or Confederation; grant Letters of Marque and Reprisal; coin Money; emit Bills of Credit; make any Thing but gold and silver Coin a Tender in Payment of Debts; ... or grant any Title of Nobility." Once again, the items Bradley explicitly included seem much more closely connected with classic common law rights of the individual to liberty and property than the items he excluded. What common law right would be violated by a state's granting of a title of nobility?

Far more direct was John Randolph Tucker's famous oral argument in the 1887 Chicago anarchist case, Spies v. Illinois. Here for the first time, an attorney before the Court clearly argued for incorporation on the basis of the privileges or immunities clause. But Tucker's brand of incorporation was distinctly more refined than Black's. Like Bradley, Tucker included in his catalogue of privileges and immunities those rights "declare[d]" in the original Constitution, as well as the Bill, including "the security for habeas corpus [and] the limits imposed on Federal power in the Amendments and in the original Constitution as to trial by jury, \&c."324 When he turned his eye to the Bill proper (which he labeled "the Declaration of Rights"), he made explicit the common law filter that Bradley had only implied:

Though originally the first ten Amendments were adopted as limitations on Federal power, yet in so far as they secure and recognize fundamental rights-common law rights - of the man, they make them privileges and immunities of the man as citizen of the United States, and [those privileges] cannot now be abridged by a State under the Fourteenth Amendment. In other words, while the ten Amendments, as limitations on power, only apply to the Federal government, and not

323. Id. (emphasis altered).

324. Spies v. Illinois, 123 U.S. 131,151 (1887) (oral argument). 
to the States, yet in so far as they declare or recognize rights of persons, these rights are theirs, as citizens of the United States, and the Fourteenth Amendment as to such rights limits state power .... ${ }^{325}$

Tucker strained-rather unconvincingly-to introduce further modifications of his basic model to accommodate post Slaughter-House precedent, ${ }^{326}$ but his general approach was both revealing and helpful.

The Court disposed of Spies without reaching the issues raised by Tucker. Five years later, Justice Field, joined by Justices Harlan and Brewer, ranged far beyond the narrow pleadings in the case before him to embrace Tucker's argument: "[A]fter much reflection I think the definition given at one time before this court by a distinguished advocate-Mr. John Randolph Tucker, of Virginia-is correct." ${ }^{1327}$ Field went on to distinguish between those aspects of the Bill that were mere "limitations on power" and those that instead "declare or recognize the rights of persons. ${ }^{\text {"328 }}$ Some of Field's hinted applications of this distinction appear doubtful-once again, it seems, the result of an awkward effort to accommodate post-Slaughter-House precedents on grand and civil juries. ${ }^{329}$ But we are concerned here not with individual applications, but with a basic model for incorporation; and the Van Ness/Tucker/Field distinction, or something like it, is what we need to sort out those aspects of the pre-1866 Constitution that sensibly incorporate from those that do not.

By 1900 , Justice Field had left the Court, but Justice Harlan continued to carry on the crusade to breathe life back into the privileges or immunities clause. His first extended analysis of the clause came in Maxwell v. Dow, where he vigorously argued that all the personal rights, freedoms, privileges, and immunities in the "National Bill of Rights" applied against states by dint of the Fourteenth Amendment. ${ }^{330}$ Yet once again, if we examine the evidence closely, we see a more refined approach than Black would later offer. Thus, in canvassing the rights and freedoms of the First Amendment, Harlan quoted or paraphrased each of its clauses except establishment. ${ }^{331}$ Moments later, he offered the following hypothetical:

Suppose the State of Utah should amend its constitution and make the Mormon religion the established religion of the State, to be supported by taxation on all the people of Utah. ... If such an amendment were alleged to be invalid under the National Constitution, could not [today's opinion] be cited as showing that the right to the free exercise

325. Id. (emphasis added).

326. Id. at 152 (attempting to distinguish Hurtado v. California, 110 U.S. 516 (1884), and Walker v. Sauvinet, 92 U.S. 90 (1875), which had rejected Fourteenth Amendment incorporation of the Bill's grand jury and civil jury requirements against states).

327. O'Neil v. Vermont, 144 U.S. 323, 361 (1892) (Field, J., dissenting).

328. Id. at 363 .

329. Id. at 362 .

330. Maxwell v. Dow, 176 U.S. 581, 614-15 (1900) (Harlan, J., dissenting).

331. Id. at 615 . 
of religion was not a privilege of a "citizen of the United States" within the meaning of the Fourteenth Amendment? ?32 $^{32}$

Harlan's decision to characterize this hypothetical fact pattern as violating free exercise rather than nonestablishment principles is subtle but significant. To infringe upon the free exercise of religion is necessarily to invade individual rights of property and bodily liberty, but perhaps not all establishments would do so. Would a simple legislative declaration that "Utah is a Mormon State" infringe classic common law rights of liberty and property any more than a granting of a title of nobility? Harlan instead pointedly chose a hypothetical involving state taxation depriving individual taxpayers of their property and indirectly compelling them to affirm religious beliefs contrary to their own. Though he offered less elaboration than Tucker, he too seemed to be using an implicit common law filter. Indeed, without some such filter, Harlan's approach would be hard to fathom, for like Tucker and Field, but unlike Black, Harlan spoke again and again of "the first ten" rather than eight amendments. ${ }^{333}$

Harlan returned to the privileges or immunities clause eight years later in his celebrated dissent in Twining $v$. New Jersey, a case raising the question whether a state could compel a citizen to incriminate himself. Though tipping his hat to Barron, Harlan described the privilege against compelled self-incrimination as an English common law privilege preexisting the federal Constitution. ${ }^{334}$ In language reminiscent of Corfield's ode, Harlan wrote that "real, genuine freedom could not exist in any country" that abridged this freedom, which ranked "among the essential, fundamental principles of English law.",335 For Harlan, rights declared in "the name of the people" by the original Bill of Rights became applicable against the states via the Fourteenth Amendment; but once again, Harlan filtered the Bill through the common law, stressing "privileges and immunities mentioned in the original Amendments, and universally regarded as our heritage of liberty from the common law."336

Nineteenth-century lawyers and judges who took incorporation seriously thus point us toward a considerably more refined brand of incorporation than Justice Black-or any other twentieth-century figure, for that matter-served up.

\section{C. "Refined Incorporation" Applied: The Rights of Expression}

What would acceptance of the refined incorporation model mean in practice? A full demonstration of the model's application to each and every clause

332. Id. at 615-16 (emphasis added).

333. Id. at $607,608,612,617$; see also Spies v. Illinois, 123 U.S. 131, 151 (1887) (Tucker's oral argument); O'Neil, 144 U.S. at 361-63 (Field, J., dissenting).

334. Twining v. New Jersey, 211 U.S. 78, 117-18 (1908) (Harlan, J., dissenting).

335. Id. at 118.

336. Id. at 122 . 
of the original Bill must await another day; ${ }^{337}$ but the speech, press, petition, and assembly clauses of the First Amendment provide a handy testing ground, illustrating the analytic virtues of the refined model, and the kinds of insights made possible by it.

"Congress shall make no law ... abridging the freedom of speech, or of the press; or the right of the people peaceably to assemble, and to petition the Government for a redress of grievances." Textually, the argument for applying these rights against states via the Fourteenth Amendment is wonderfully straightforward. The First Amendment explicitly speaks of "right[s]" and "freedom[s]" (entitlements also known as "privileges" and "immunities"), and the Amendment's words that these rights "shall" not be "abridg[ed]" by "law" perfectly harmonize with their echoes in the key sentence of Section One. ${ }^{338}$ Nor can it be argued that these "rights" and "freedoms" are somehow not private rights of individual citizens. Though narrower in scope than their American counterparts, the freedoms of press, petition, and peaceable assembly were, according to Blackstone, core common law rights "of persons" and of "every freeman." 1780 's by American popular sovereignty theory, which also extended to ordinary citizens the freedom of speech previously enjoyed only by legislators. ${ }^{340}$

Of course, federalism played an important role in the original First Amendment, but not in a way that impedes incorporation of its explicit rights and freedoms. Even if we assume that freedom of speech in state legislatures enjoyed special First Amendment status above and beyond the freedom of ordinary citizens, ${ }^{341}$ nothing about incorporation takes away state legislatures' freedom of speech; incorporation simply limits their freedom to use state law to silence ordinary citizens, and that freedom is not in any way protected by the First Amendment. For example, the Amendment nowhere forbids Congress to "make any law protecting freedom of speech" and so on against repressive state action. On the contrary, a strong argument can be made that Congress was empowered and perhaps required to pass precisely these sorts of laws to vindicate the Article IV guarantee that each state would have a republican government. Could such a government ever punish citizens for speaking, writing, peaceably assembling, or petitioning against it?

Many Barron contrarians in the antebellum era thought not. Today, we might at first wonder how faithful interpreters of the First Amendment could earnestly argue, even before 1866 , that its protections of free expression could bind states; but few moderns have any problems seeing a Presidential censor-

337. A more complete presentation shall appear in my forthcoming book.

338. See supra text accompanying notes 117-18.

339. 1 BLACKSTONE, supra note 126 , at *143 (petition and assembly); 4 id. at *152 (press).

340. See supra text accompanying notes 311-14.

341. See Amar, supra note $\dagger$, at $1151-52$. 
ship edict, or a judicial contempt order imprisoning a reporter critical of the court, as raising "First Amendment" concerns. ${ }^{342}$ To be sure, the Amendment speaks only of "Congress"; but any automatic expressio unius inference that citizens therefore lack analogous rights against the President or federal judges-or states-flies in the face of the Ninth Amendment. Thus, when supporters of the Fourteenth Amendment described its provisions as "declaratory" of the existing Constitution, properly construed, we must not assume that they necessarily meant to include only those generally worded provisions of the Bill of Rights and to exclude those clauses explicitly linked to Congress.

Thus, neither the First Amendment's arguably special protection of state legislative speech, nor its use of the word "Congress" presents any stumbling block to incorporation. But a third federalism component of the original Amendment does raise an interesting incorporation question. The particularly absolutist phrasing of the First Amendment-"Congress shall make no law"-may well have reflected a widespread understanding in 1789 that Congress simply lacked enumerated power to suppress speech, etc. ${ }^{343}$ To this extent, the First Amendment resembled the Tenth, specifying not a private right of citizens based on personal liberty, but a state right rooted in federalism. And under the model of refined incorporation, the federalism aspect of First Amendment absolutism does not sensibly incorporate against states. But then, we are left with a seeming paradox: the First Amendment might constrain Congress more strictly than the Fourteenth constrains states even though both Amendments seem to speak with one voice, that the freedom of speech, etc., "shall" not be "abridg[ed]" by "law."

The paradox is more apparent than real. As a practical matter, we must of course remember that the federalism-based argument for First Amendment absolutism has never been taken seriously by federal courts and is unlikely to be revived in the modern era. But if the theory ever were taken seriously, it could indeed permit differential treatment of state and federal governments. ${ }^{344}$ Even if couched as an interpretation of the First Amendment, federalism-based absolutism is ultimately rooted elsewhere-in a strict interpretation of Article I, Section 8 claiming that Congress lacks enumerated power to censor. But nothing in the text, history, or logic of the Fourteenth Amendment suggests that the federal system of enumerated powers should be overlaid on-incorporated against-states. Put another way, if we take federalism seriously, even before we reach the question whether federal power is trumped by the First Amendment in a given area, we must ask an analytically prior question: does the

342. In discussing the "reflex character" of the First Amendment as declaratory of principles applicable against states, the first Justice Harlan also noted that the Amendment's principles bound not just Congress, but federal courts. See Patterson v. Colorado, 205 U.S. 454, 464 (1907) (Harlan, J., dissenting).

343. See supra note 38 and text accompanying note 53; see also Mayton, supra note 312, at 117-19; William W. Van Alstyne, Congressional Power and Free Speech: Levy's Legacy Revisited, 99 HARV. L. REV. 1089, 1095-96 (1986) (book review).

344. See WILLIAM W. VAN ALSTYNE, INTERPRETATIONS OF THE FIRST AMENDMENT 43-46 (1984). 
Constitution in fact grant the federal government power here? And if the answer is no, we must not assume that state governments also necessarily lack power-for perhaps Congress is denied a particular power precisely because the Constitution meant to leave it to the states.

At first, the federalism-based reading of the First Amendment might seem tailor-made for Hugo Black, who championed First Amendment absolutism, preached fidelity to the Founders" "original intent," and also proved willing to invalidate acts of Congress on federalism grounds. ${ }^{345}$ Yet Black never relied on federalism to bolster his First Amendment absolutism, and with good reason. Such a move would have driven an analytic wedge between the First and Fourteenth Amendments, thereby destroying Black's own theory of mechanical incorporation. This wedge would not necessarily require abandonment of absolutism in free speech cases involving states: Black could well have defended First Amendment absolutism on grounds of both federalism and freedom, and the latter set of arguments clearly would apply equally against states. But if Black had ever admitted that any of the provisions of Amendments I-VIII had any federalism component whatsoever, he would have been forced to admit the analytical possibility that perhaps not all of his (redefined) Bill of Rights sensibly incorporated jot for jot. The entire analytic structure of total incorporation would have crumbled.

But even if Black's precise analytic path to incorporation of speech, press, petition, and assembly cut a few corners, he ended up in the right place: as a matter of constitutional text and structure, these clauses are indeed easy cases for full application against states via the Fourteenth Amendment. An ounce of history here provides powerful confirmation. From the 1830 's on, the abolitionist crusaders had understood that freedom of speech for all men and women went hand in hand with freedom of bodily liberty for slaves. The Slave Power posed a threat to Freedom —of all kinds-and could support itself only through suppression of opposition speech, with gag rules on antislavery petitions, bans on "incendiary" publications, intrusions on the right of peaceable assembly, and so on. ${ }^{346}$ This global theory of Freedom was not limited to a few lawyers or theorists spearheading the crusade, but was quite literally the popular platform

345. See, e.g., Oregon v. Mitchell, 400 U.S. 112 (1970).

346. See generally CLEMENT EATON, THE FREEDOM-OF-THOUGHT STRUGGLE IN THE OLD SOUTH (1964); RUSSEL B. NYE, FETTERED FREEDOM (1963); WILLIAM S. SAVAGE, THE CONTROVERSY OVER THE DISTRIBUTION OF ABOLITION LITERATURE 1830-1860 (1938); FONER, supra note 105, at 100-01, 122-23; HYMAN \& WIECEK, supra note 105, at 118-19; NELSON, supra note 64, at 42-43; WIECEK, supra note 99, at 172-82; Howard Jay Graham, The Early Antislavery Backgrounds of the Fourteenth Amendment, 1950 WIS. L. REV. 479, 610, 632-47; William E. Nelson, The Impact of the Antislavery Movement Upon Styles of Judicial Reasoning in Nineteenth Century America, 87 HARV. L. REV. 513, 533-37 (1974); see also sources cited supra note 107.

Perhaps the most dramatic incident occurred in 1856 on the floor of the U.S. Senate, where South Carolina Congressman Preston Brooks attacked the defenseless Massachusetts Senator Charles Sumner with a cane and beat him into bloody unconsciousness in retaliation for an antislavery speech Sumner had made on the floor of the Senate a few days earlier. Many Northemers were shocked, but many Southern citizens and governments applauded Brook's action, sending him complimentary canes and bullwhips. 
of the antislavery movement, perhaps best exemplified by an 1856 Republican Party campaign slogan: "Free Speech, Free Press, Free Men, Free Labor, Free Territory, and Frémont."347

During the Thirty-eighth and Thirty-ninth Congresses, Republicans invoked speech, press, petition, and assembly rights over and over-more frequently than any other right, with the possible exception of due process. ${ }^{348}$ These invocations occurred in a variety of overlapping contexts: as glosses on the "civil rights" to be protected by the Civil Rights and Freedman's Bureau Acts; as part of the definition of republican government (whose violation justified continued Southern exclusion from the national legislature); as "fundamental rights" of all citizens; and as paradigmatic "privileges or immunities" of national citizenship and/or interstate comity.

Once again, the centrality of these rights was not an idea limited to a few leading lawyers or theorists, but was widely understood by the polity. Various petitions from ordinary constituents to Congress in 1866 stressed the importance of the rights of "speech," "press," and "assembly" (while of course embodying the interrelated right of petition); ${ }^{349}$ the New York Evening Post noted that the freedoms of speech and of the press were guaranteed by the Civil Rights Act (even though the Act did not explicitly speak of those freedoms) and later read Section One of the proposed Amendment as covering the same ground; ${ }^{350}$ the Philadelphia North American and United States Gazette in September 1866 listed freedoms of speech, press, and assembly as paradigmatic "privileges and immunities" of citizenship within the meaning of the thenpending Amendment, ${ }^{351}$ various prominent Congressmen on the campaign trail in 1866 (including Bingham, Wilson, and Speaker of the House Schuyler Colfax) emphasized the Amendment's protection of freediom of speech, ${ }^{352}$ state politicians in leading Northern states-Wisconsin, Pennsylvania, Ohio, Massachusetts, New York, and so on-linked the Amendment to freedom of discussion; ${ }^{333}$ and various popular 1866 conventions, both Northern and Southern, not only embodied the right to peaceably assemble, but used these

347. CURTIS, supra note 106, at 32; see also NATTONAL PARTY PLATFORMs 1840-1968, supra note 105, at 7 (Liberty Platform of 1844 condemning "all rules, regulations and laws, in derogation" of "freedom of speech and of the press, and the right of petition," rights labeled "sacred and inviolable").

348. See, e.g., CONG. GLOBE, 38th Cong., 1st Sess. 1202, 1313, 1439, 2615, 2990 (1864) (remarks of Rep. James Wilson, Sens. Lyman Trumbull and James Harlan, and Reps. Daniel Morris and Ebon Ingersoll); CONG. GLOBE, 38th Cong., 2d Sess. 138, 193, 237 (1864) (remarks of Reps. James Ashley, John Kasson, and Green Smith); CONG. GLOBE, 39th Cong., 1st Sess. 474-75, 1066, 1072, 1263, 1617 (1866) (remarks of Sen. Lyman Trumbull, Rep. Hiram Price, Sen. James Nye, and Reps. John Broomall and Samuel Moulton).

349. CONG. GLOBE, 39th Cong., 1st Sess. 337, 436, 494 (1866) (petitions presented by Sens. Charles Sumner, Lyman Trumbull, and Jacob Howard).

350. FLACK, supra note 146 , at $42,143$.

351. ANTIEAU, supra note 113 , at 32 .

352. Id. at 24 (Bingham and Rep. Columbus Delano); CURTIS, supra note 106, at 138-39, 144-45 (Bingham, Wilson, Delano, Reps. William D. Kelly and William Boyd Allison, and Sen. Richard Yates); FLACK, supra note 146, at 149 (Colfax).

353. ANTIEAU, supra note 113 , at 24-25, 30-33; CURTIS, supra note 106 , at $140,145-53$. 
occasions to reaffirm the importance of speech, press, petition, and assembly rights. ${ }^{354}$

Thus far, the refined incorporation model and Black's total incorporation approach appear to converge. But refined incorporation can help us to see what Black's approach obscured: how the very meaning of freedom of speech, press, petition, and assembly was subtly redefined in the process of being incorporated. In the eighteenth century the paradigmatic speaker was someone like John Peter Zenger or James Callender, ${ }^{355}$ a relatively popular publisher saying relatively popular things critical of less popular government officials. In the mid-nineteenth century the paradigm shifted to the Unionist, the abolitionist, and the freedman: to speakers like Samuel Hoar, Harriet Beecher Stowe, and Frederick Douglass. Hoar was a Massachusetts lawyer who in 1844 went to South Carolina with his daughter to defend the rights of free blacks, only to be literally ridden out of town on a rail by an enraged populace after the South Carolina legislature passed an act of attainder and banishment. ${ }^{356}$ A generation later, Hoar's cause célèbre still burned brightly in the memories of members of Congress who repeatedly cited the incident. ${ }^{357}$ Stowe, of course, authored the "incendiary" bestseller Uncle Tom's Cabin in the 1850's-a novel that outraged the pro-slavery South and inspired the anti-slavery North, leading Lincoln to describe her as "the little woman who wrote the book that made this great war." 358 Frederick Douglass escaped from slavery in Maryland in 1838, published a daring autobiography in 1845, founded and edited a leading abolitionist newspaper over the next two decades, and became a preeminent orator on behalf of civil rights and suffrage for both women and freedmen.

The shift from Zenger and Callender to Hoar, Stowe, and Douglass was subtle but significant. All can be seen as "outsiders," but with an important difference. As representatives of the Fourth Estate, Zenger and Callender were "outside" the government that sought to censor them, but Hoar, Stowe, and Douglass were outsiders in a much deeper sense. Vis-à-vis the Southern society trying to suppress their speech, Hoar, Stowe, and Douglass were geographic, cultural, and ethnic outsiders who were critical of dominant social institutions and opinions. Put another way, this shift directs us away from Madison's first

354. See, e.g., CuRTIS, supra note 106, at 135 (quoting appeal from convention of Southern loyalists denouncing slave state violations of "constitutional guarantees of the right to peaceably assemble and petition for redress of grievances" and of "constitutional guarantees of freedom and free speech and a free press").

355. On Callender, see Amar, supra note $t$, at 1191.

356. For an account, see 1 HENRY WLSON, HISTORY OF THE RISE AND FALL OF THE SLAVE POWER IN AMERICA 578-82 (1875).

357. See CONG. GlobE, 38th Cong., 1st Sess. 2984 (1864) (remarks of Rep. William Kelley); CoNG. GLOBE, 38th Cong., 2d Sess. 193, 237 (1865) (remarks of Reps. John Kasson and Green Smith); CoNG. GLOBE, 39th Cong., 1st Sess. 41, 157, 475 (1865-66) (remarks of Sen. John Sherman, Rep. John Bingham and Sen. Lyman Trumbull); id. at 142 app. (remarks of Sen. Henry Wilson); see also ANTIEAU, supra note 113, at 24 (quoting 1866 remarks of Rep. Columbus Delano); Fairman, supra note 113, at 22 (Samuel Hoar episode was "stock example" in Reconstruction Congress).

358. Charles E. STOWE \& LYMAN B. STOWE, HARRIET BEecher STOWE: THE STORY OF HeR LIFE 202-03 (1911). 
concern in The Federalist No. 51 (the "agency" problem of protecting the people against unrepresentative government), toward his second concern (protecting minorities from "factional" majority tyranny). ${ }^{359}$ The new First/Fourteenth Amendment tradition is less majoritarian and more libertarian. ${ }^{360}$ To recast this point in a temporal frame, the abolitionist experience dramatized why even majoritarians should logically support strong First Amendment protections for offensive and provocative speech of fringe groups. For if allowed to freely preach their gospel, a zealous fringe group in one era (like proponents of abolition, equality, and black suffrage in 1830) could conceivably convert enough souls to their crusade to become a respectable or even dominant political force over the next generation (like the Republican Party of the 1860's).

My language here - "preach," "gospel," "zealous," "convert," "souls," and "crusade"-reflects the religious inspiration of many abolitionists. ${ }^{361}$ For example, Stowe's husband, father, and many brothers were famous New England clergymen. The well publicized martyrdom of Elijah Lovejoy also dramatized the centrality of religious speech. Lovejoy, a Presbyterian minister, used his church weekly to condemn slavery. His writings cost him his life in 1837 when he was murdered by an angry mob bent on silencing his press.

Republicans naturally understood the religious roots of abolitionism, and often stressed the need to protect religious speech. We have already noted Bingham's 1859 speech proclaiming the centrality of the right to "utter according to conscience;" 362 and on the campaign trail in 1866 he reminded his audience that men had been imprisoned in Georgia for teaching the Bible, and made clear that the Fourteenth Amendment would put an end to such state action, a theme to which he returned in a key speech on the Amendment before the House in $1871 .^{363}$ In early 1866, Lyman Trumbull introduced his Civil Rights Bill by stressing the need to protect the freedom "to teach" and "to preach," citing a Mississippi Black Code punishing any "free negroes and mulattoes" who dared to "exercis[e] the functions of a minister of the Gos-

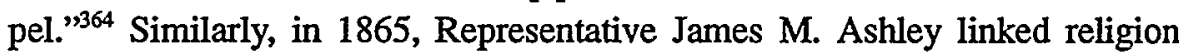
to freedom of speech in the following way: "[The Slave Power] has silenced

359. The distinction between these two concerns is a major theme of my earlier work on the Bill of Rights, see Amar, supra note $\dagger$.

360. See, e.g., CONG. GLOBE, $42 \mathrm{~d}$ Cong., 1st Sess. 380 (1871) (remarks of Rep. John Hawley) (on need to protect "freedom of speech" contrary to "dominant" opinion).

361. See generally Graham, supra note 346.

362. See supra text accompanying note 181 .

363. ANTIEAU, supra note 113, at 24; CONG. GlOBE, $42 d$ Cong., 1st Sess. 84 app. (1871).

364. CONG. GLOBE, 39th Cong., 1st Sess. 474-75 (1866); see also TENBROEK, supra note 64, at 124-25 (discussing centrality in abolitionist theory of right to "teach or be taught the Gospel" to nourish the "immortal mind"). 
every free pulpit within its control ... and made free speech and a free press impossible within its domain ....."365

In 1789, the freedoms of speech and press had been yoked with religious freedoms largely for reasons of federalism: both religious regulation and press censorship were seen as beyond Congress' enumerated powers. ${ }^{36}$ This federalism-based reading of the original First Amendment draws support from the dramatic fact that no previous state constitution had linked these two sets of rights in a single provision. But once yoked together in the federal Bill, these clauses helped reinforce a libertarian theory of freedom of all expression-political, religious, and even artistic (Uncle Tom's Cabin was of course all three). By the 1860's, libertarianism had displaced federalism and majoritarianism as the dominant, unifying theme of the First Amendment's freedoms.

The centrality of religious speech in the 1860 's proved especially significant for women. Though excluded from exercising the formal political rights of voting, holding public office, and serving on juries or militias, women could and did play leading roles in religious organizations. Moreover, these organizations engaged in moral crusades with obvious political overtones: temperance, abolition, and (eventually) suffrage. As a result, the voice of women was much harder to ignore in the 1860's than it had been in the 1790's. In the debates over the Constitution and Bill of Rights, only one woman-Mercy Otis Warren-had participated prominently, and even then under a pseudonym. (Indeed, her most important pamphlet during the ratification debates was long ascribed to Elbridge Gerry, and was not credited to her until 1932.). ${ }^{367}$ In 1866, however, the most widely read condemnation of slavery had been authored by a woman (Stowe); and in a campaign orchestrated by Susan B. Anthony and Elizabeth Cady Stanton, thousands and thousands of women flooded the Thirtyninth Congress with petitions on the issue of women's suffrage, which had been largely a nonissue for the Founding Fathers. ${ }^{368}$ At least five petitions from women on the suffrage issue were presented on the floor of Congress in the first two months of 1866 alone. ${ }^{369}$ Women were therefore central exercisers of First Amendment freedoms in the Reconstruction era in a way they had not been at the Founding-yet another example of the rising importance of "outsider" speech. Interestingly, in discussing the Hoar affair before the Thirty-eighth Congress, Representative William D. Kelley pointedly spoke of not only Samuel Hoar, but also his "beautiful and accomplished daughter." ${ }^{370}$ So, too,

365. CoNG. Globe, 38th Cong., 2d Sess. 138 (1865); see also CONG. Globe, 38th Cong., 1st Sess. 2615 (1864) (remarks of Congressman Daniel Morris) (discussing incarceration of "Christian men and women for teaching the alphabet" (emphasis added)).

366. My book shall present more documentation and analysis of this claim.

367. See Charles Warren, Elbridge Gerry, James Warren, Mercy Warren and the Ratification of the Federal Constitution in Massachusetts, 64 MASS. HIST. SOC'Y PROc. 143 (1932).

368. See Nina Morais, Note, Sex Discrimination and the Fourteenth Amendment: Lost History, 97 YALE L.J. 1153, 1155-56 (1988).

369. Id. at 1156 .

370. CONG. GLOBE, 38th Cong., 1st Sess. 2984 (1864). 
Representative John Kasson noted that "innocent ladies, cultivated, intelligent, Christian women, have been driven from the cities and States of the South ... because they had dared to say something offensive to this intolerant spirit of slavery," and Representative Morris reminded his audience that Southern states had "incarcerated Christian men and women for teaching the alphabet."

Just as the centrality of religious speech helped bring women into the core of the First Amendment, it also helped blacks. As with women, the exclusion of blacks from formal political rights like voting underscored the importance of their participation in other organizations like churches, that could help focus the voice of the community. Southern governments, of course, were all too aware of the "incendiary" dangers posed by any assembly of blacks, even (or perhaps especially) an assembly of God. After all, Nat Turner, who had led a famous slave revolt in the 1830's, had been a black preacher-hence the Mississippi Black Code cited by Trumbull, prescribing thirty-nine lashes for any black exercising the functions of a minister. ${ }^{372}$ But Republicans like Trumbull strongly affirmed the "civil" rights of blacks to assemble and preach, even as these same Republicans disclaimed any intent to confer "political" rights like the franchise upon blacks. ${ }^{373}$ Charles Sumner provided the Joint Committee on Reconstruction yet another dramatic example of black speech, laying before the Committee a petition "from the colored citizens of South Carolina," claiming to represent "four hundred and two thousand citizens of that State, being a very large majority of the population." Unsurprisingly, the petition prayed for "constitutional protection in keeping arms, in holding public assemblies, and in complete liberty of speech and of the press." ${ }^{374}$

The gloss of the Fourteenth Amendment experience on the First Amendment text has important doctrinal implications. As the paradigmatic speech in need of constitutional protection shifts from a localist criticizing the central government to a Unionist defending its Reconstruction policies, carpetbagging federal judges appointed in Washington, D.C. become more trustworthy guardians of First Amendment freedoms than localist juries. When the core of the Amendment was protection of the people collectively from unrepresentative government, perhaps an unelected federal judge on the federal payroll was a more suspect sentry; ${ }^{375}$ but when the central mission of free speech shifted to protection of currently unpopular ideas from a current majority, an Article III officer with life tenure, sheltered from current political winds and sensitive to the long-term value of free speech, enjoyed certain advantages over a jury structured to reflect today's dominant community sentiment. If women and blacks were central speakers in the Reconstruction paradigm, would a jury of

371. CONG. GLOBE, 38th Cong., 2d Sess. 193 (1865); CONG. GLOBE, 38th Cong., 1st Sess. 2615 (1864).

372. See Cong. Globe, 39th Cong., 1st Sess. 474 (1866).

373. See supra text accompanying note 295.

374. CONG. GlOBE, 39th Cong., 1st Sess. 337 (1866).

375. See Amar, supra note $\dagger$, at 1150-51, 1191-95. 
twelve white men be in every sense a jury of their "peers"? And if not, there was less reason to expect that such a jury would represent their interests and rights any better than would a federal judge.

Thus, it is largely the Fourteenth Amendment experience, I submit, that best justifies the emphasis in modern First Amendment doctrine on federal judges, rather than juries, as guardians of free speech. Yet the reigning doctrinal approach of jot for jot incorporation has obscured the significance of the Fourteenth Amendment, which all but drops out of the free speech picture. Advocates and scholars focus all their analytic and narrative attention on the Founding, not the Reconstruction. Thus, in championing the rights of Communists and Jehovah's Witnesses in the twentieth century, the ACLU has analogized to Zenger more than to the abolitionists-who are the truer forebears of modern political and religious speakers perceived as "nuts" and "cranks" by the dominant culture. Similarly, in the landmark First Amendment case of our era, New York Times Co. v. Sullivan, Justice Brennan quoted Madison and thoughtfully reflected on the lessons of the Alien and Sedition Act controversy, but said virtually nothing about the Reconstruction Amendment except that it incorporated the First Amendment against states (presumably jot for jot). ${ }^{376}$ Yet the facts before the Court in Sullivan almost cried out for comparison with the Reconstruction era. Southern followers of the Reverend Martin Luther King, many of them black and many of them religious, had used a Northern newspaper to criticize Southern officials; and a Southern jury composed of good ole boys had socked the speakers with massively punitive damages. Many of the doctrinal rules crafted by Sullivan and its progeny reflect obvious suspicion of juries-resulting, for example, in various issues being classified as legal questions or mixed questions of law and fact inappropriate for unconstrained jury determination ${ }^{377}$-yet that suspicion is much better justified by the Reconstruction experience than by the Founding.

But if various jury-restricting doctrines are indeed products of the interaction between the First and Fourteenth Amendments, how to justify the Court's application of these doctrines in pure First Amendment cases involving only the federal government? Can it be argued that the Fourteenth Amendment has a doctrinal "feedback effect" against the federal government, despite the Amendment's clear textual limitation to state action?

Yes it can. To begin with, consider Professor Monaghan's reminder that constitutional text does not specify precisely which institutional, procedural, and doctrinal rules best implement the First Amendment's substantive values. ${ }^{378}$ In Monaghan's elegant phrase, the text does not supply a complete theory of "First Amendment due process," specifying, for example, the precise

376. New York Times Co. v. Sullivan, 376 U.S. 254 (1964).

377. See, e.g., William J. Brennan, Jr., The Supreme Court and the Meiklejohn Interpretation of the First Amendment, 79 HARV. L. REV. 1, 7-8 (1965).

378. Henry P. Monaghan, First Amendment "Due Process," 83 HARV. L. Rev. 518 (1970). 
respective roles of judge and jury. In crafting such a theory, interpreters must obviously consider the First Amendment's primary purpose - but this too is not textually specified, so structural inferences may thus loom larger. For example, the failure of the original First Amendment to explicitly restrict state legislation, combined with Madison's structural observation in The Federalist No. 10 that state governments were more majoritarian than Congress, plausibly implies that the core purpose of the original First Amendment was to prevent not majority tyranny, but self-dealing by unrepresentative government agents. ${ }^{379}$ Given an agency-cost theory of free speech, a jury may well be the best guardian of the First Amendment's core - a conclusion buttressed by the efforts of eighteenthcentury speakers like Zenger and Callender to appeal from judge to jury. ${ }^{380}$ But if the original "First Amendment due process" theory is built in part on structural inferences from Barron, then Barron's repudiation by the Fourteenth Amendment requires us to rethink the original assumptions that led us to juries. Once the Fourteenth Amendment is on the books, the "agency" theory of free speech is less explanatory than the minority-protection theory since the latter better accounts for speech limitations on majoritarian state legislatures. And the minority-protection theory suggests a different optimal allocation between judge and jury. To put the structural point textually, the parallel language between the First Amendment and the Fourteenth should strongly incline us towards a unitary theory of freedom of speech against both state and federal governments.

It might at first seem as if we have once again simply reached the same result as Hugo Black-identical treatment of First and Fourteenth Amendment speech cases-but by a much more tortuous route. On the contrary, refined incorporation reaches a different conclusion from Black's: that "freedom of speech" was subtly redefined in 1866 , just as "freedom of the press" was subtly redefined in $1789 .{ }^{381}$ The 1866 redefinition changed the central purpose and optimal "due process" implementation of freedom of speech, making central certain types of speech that had previously been far more peripheral: religious speech, artistic speech and, most importantly, minority speech.

We can chart a similar inversion of core and periphery in "the right of the people peaceably to assemble, and to petition." These words, as originally written, linked up tightly to popular sovereignty theory. In its strictest sense, "the people" encompassed voters-the same adult male citizens who, roughly speaking, constituted "the militia" equated with "the people" in the very next sentence of the Bill of Rights. And the paradigmatic exercise of (We) "the [P]eople's" right to assemble was a constitutional convention called by political rights-holders (adult male citizens) to alter or abolish government. Other meanings of "the people" and "assembly" were also encompassed, but popular

379. Indeed, so I have argued elsewhere. See Amar, supra note $\dagger$, at 1146-52.

380. See id. at 1150-51, 1191-95.

381. See supra text accompanying notes 310-14. 
sovereignty theory colored the Amendment's core. ${ }^{382}$ By 1866, all this had subtly changed. The phrase "the people" was still read relatively strictly-we have seen, for example, that the Senate refused to allow foreigners to petition $^{383}$ - but clearly encompassed those who were not political rights-holders. American women deluged the 1866 Congress with petitions precisely because they were not voters. So too, Sumner's petition from the South Carolina "convention" of "colored citizens" came from a group excluded from the vote, the militia, and the jury-excluded from the polity, strictly defined. Likewise, while the debate on the Fourteenth Amendment was drawing to a close in the Thirty-ninth Congress, another prominent convention of nonvoters-the Eleventh Women's Rights Convention-was meeting in New York City. ${ }^{384}$

In introducing a women's suffrage petition in 1866, Senator Thomas Henderson sharply distinguished between the rights of suffrage and petition: "The right of petition is a sacred right, and whatever may be thought of giving the ballot to women, the right to ask it of the Government [by petition] cannot be denied them. ${ }^{2385}$ Though dubious of granting women the political right of the vote, Henderson declared that "no civil right," presumably including the right to petition, "can be denied her."386 In a similar vein, the Republican New York Evening Post rejected the notion that the Civil Rights Act embraced political rights like jury service and office holding, but cheerfully conceded that the rights of speech, press, petition, and assembly, though unenumerated, were clearly covered by the Act. ${ }^{387}$ So too, in Professor tenBroek's rich account of abolitionist theory in the antebellum era, the core right of assembly at issue seems to be the right of blacks "to assemble peaceably on the Sabbath for the worship of [the] Creator." 338

In a nutshell, the hybrid rights of petition and assembly were increasingly being characterized as civil, not political rights-a shift reflected in and perhaps caused by the exercise of these rights by women and blacks. Petitions and assemblies by the disenfranchised were no longer seen as peripheral to, or derivative of, a popular sovereignty core celebrating the right of the (political) people to (re)assemble, through specially elected representatives, in constitutional conventions. Whereas the lived experience of $1787-89$, with precisely such conventions of "the people" actually assembling, glossed the text with popular

382. See Amar, supra note $t$, at 1152-55.

383. See supra text accompanying note 152 .

384. JAMES, supra note 201 , at 130.

385. CONG. GLOBE, 39th Cong., 1st Sess. 951 (1866). The feminist leader Elizabeth Cady Stanton agreed that under extant law, petition was "the only right [woman] has in the Government" ELIZABETH CADY STANTON, EIGHTY YEARS AND MORE 244 (Schocken Paperback ed. 1971) (1898) (reprinting letter dated Jan. 2, 1866); see also SARAH GRIMKE, LETTERS ON THE EQUALITY OF THE SEXES AND OTHER ESSAYS 71, 72 (Elizabeth Ann Bartett ed., 1988) (reprinting September 6, 1837 letter on legal disabilities of women: "Woman has no political existence. With the single exception of presenting a petition to the legislative body, she is a cipher in the nation ....").

386. CONG. GLOBE, 39th Cong., 1st Sess. 952 (1866).

387. FLACK, supra note 146 , at 42 .

388. TENBROEK, supra note 64 , at 124-25. 
sovereignty theory, a different lived experience in the 1860's offered a different, civil rights gloss on the very same words.

\section{CONCLUSION}

The Fourteenth Amendment's subtle transformations of speech, press, petition, and assembly rights are by no means unique. As I hope to show in future work, similar stories can be told about many of the other clauses and doctrines of the original Bill when they chemically interact with the Reconstruction experience. With the model of refined incorporation in place, we can thus chart how the right to keep and bear arms becomes a quintessentially individual right; how a libertarian theory of privacy comes to connect the Third, Fourth, and (perhaps) Ninth Amendments; how the Tenth Amendment comes to be read out of "the Bill of Rights," and how the very phrase is thus redefined; how "rights" and "structure" come to be separated in modern constitutional discourse; and much more.

Application of this refined model of incorporation will not be simple or mechanical, but the reward will, I believe, richly repay the effort. For we are now poised to see-at first clause by clause, and then globally-what has heretofore been hidden from view: the pervasive and powerful ways that the Fourteenth Amendment has reconstructed the meaning of the Bill of Rights in both the popular and the legal mind. 